\title{
ANEXO ESTADÍSTICO
}

- Comercio exterior de León por Capítulos: Exportaciones (en miles de euros)

- Comercio exterior de León por Capítulos: Exportaciones (en porcentaje sobre total)

- Comercio exterior de León por Capítulos: Importaciones (en miles de euros)

- Comercio exterior de León por Capítulos: Importaciones (en porcentaje sobre total)

- Comercio exterior de León por Capítulos: Saldo comercial (en miles de euros)

- Comercio exterior de León por Capítulos: Tasa de cobertura (en miles de euros)

- Comercio exterior de León por Capítulos: Cuota de Exportaciones sobre Castilla y León (en porcentaje)

- Comercio exterior de León por Capítulos: Cuota de Importaciones sobre Castilla y León (en porcentaje)

- Comercio exterior de León por Capítulos: Índice de especialización simétrica respecto a España

- Comercio exterior de León por Capítulos: Diferencia interanual de las exportaciones (en miles de euros)

- Comercio exterior de León por Capítulos: Tasa de variación anual de las exportaciones

- Comercio exterior de León por Capítulos: Diferencia interanual de las importaciones (en miles de euros)

- Comercio exterior de León por Capítulos: Índice simétrico de dependencia de las exportaciones de León respecto a España

- Comercio exterior de León por Capítulos: Saldo comercial relativo

- Comercio exterior de León por Capítulos: Índice de contribución al saldo

- Comercio exterior de León por Capítulos: Exportaciones por Áreas geográficas y países (en miles de euros)

- Comercio exterior de León por Capítulos: Importaciones por Áreas geográficas y países (en miles de euros)

- Comercio exterior de León por Capítulos: Exportaciones por Capítulos a los principales países clientes (en miles de euros)

- Comercio exterior de León por Capítulos: Importaciones por Capítulos a los principales países proveedores (en miles de euros) 


\section{J.L. Placer Galán}

\section{Comercio exterior de León: Exportaciones (en miles de euros)}

\begin{tabular}{|c|c|c|c|c|c|}
\hline Capítulos & 2010 & 2011 & 2012 & 2013 & 2014 \\
\hline 01. Animales vivos & $2.358,96$ & 71,30 & $7.649,51$ & $4.638,20$ & $1.954,03$ \\
\hline 02. Carne y despojos comestibles & $20.310,12$ & $25.434,81$ & $38.358,24$ & $38.336,91$ & $36.928,04$ \\
\hline 03. Pescados, crustáceos y moluscos & $1.668,57$ & $1.454,94$ & $1.322,39$ & 675,19 & 676,40 \\
\hline 04. Leche, productos lácteos, huevos & $24.116,08$ & $27.369,89$ & $49.345,19$ & $66.985,65$ & $69.055,29$ \\
\hline 05. Otros productos de origen animal & 170,33 & 252,26 & 368,02 & 273,14 & 213,52 \\
\hline \multicolumn{6}{|l|}{ 06. Plantas vivas y productos de floricultura } \\
\hline 07. Legumbres, hortalizas & $8.485,72$ & $8.156,35$ & $8.862,56$ & $9.680,54$ & $6.626,37$ \\
\hline 08. Frutos comestibles & 442,42 & 344,80 & 881,99 & $4.402,93$ & $6.192,62$ \\
\hline 09. Café, té, yerba mate y especias & 492,75 & 545,66 & 650,25 & 697,09 & 535,41 \\
\hline 10. Cereales & $3.532,09$ & $5.396,69$ & $6.232,41$ & $7.291,29$ & $7.758,11$ \\
\hline 11. Productos de la molinería, malta & & 0,31 & & 16,93 & \\
\hline 12. Semillas y frutos oleaginosos & $5.637,44$ & $4.926,19$ & $5.275,51$ & $6.320,87$ & $8.462,25$ \\
\hline 13. Jugos y extractos vegetales & 23,79 & 12,46 & 2,73 & 2,26 & 2,59 \\
\hline 14. Materias trenzables & & & & 1,05 & \\
\hline 15. Grasas, aceite animal y vegetal & 2,07 & 139,62 & 3,56 & 295,34 & 212,76 \\
\hline 16. Conservas de carne o pescado & $2.681,01$ & $2.839,60$ & $3.033,94$ & $3.461,46$ & $3.982,15$ \\
\hline 17. Azúcares, artículos de confitería & 802,22 & $9.281,73$ & $20.316,16$ & $23.547,41$ & $22.430,59$ \\
\hline 18. Cacao y sus preparaciones & 1,51 & 1,59 & 12,81 & & \\
\hline 19. Productos de cereales, de pastelería & $2.138,54$ & $1.038,79$ & 232,64 & 147,56 & 294,61 \\
\hline 20. Conservas de verdura o fruta, zumo & $1.527,20$ & $2.362,39$ & $3.365,04$ & $3.865,20$ & $3.887,14$ \\
\hline 21. Preparaciones alimenticias diversas & $25.286,88$ & $24.895,54$ & $21.894,00$ & $18.877,14$ & $17.540,99$ \\
\hline 22. Bebidas de todo tipo (excluidos zumos) & $4.224,12$ & $5.295,23$ & $7.463,12$ & $8.218,25$ & $9.412,44$ \\
\hline 23. Residuos de la industria alimentaria & $9.076,21$ & $9.689,65$ & $9.316,24$ & $7.623,42$ & $15.363,72$ \\
\hline \multicolumn{6}{|l|}{ 24. Tabaco y sus sucedáneos } \\
\hline 25. Sal, yeso piedras sin trabajar & $3.628,89$ & $3.860,85$ & $1.194,74$ & 903,97 & $2.832,00$ \\
\hline 26. Minerales, escorias y cenizas & 156,84 & $3.015,44$ & $3.862,41$ & $2.233,99$ & $2.586,84$ \\
\hline 27. Combustibles, aceites minerales & $9.285,02$ & $8.301,83$ & $6.168,17$ & $4.602,46$ & $5.244,70$ \\
\hline 28. Productos químicos inorgánicos & 0,29 & 491,33 & 5,54 & 10,00 & 0,56 \\
\hline 29. Productos químicos orgánicos & $34.385,25$ & $26.130,24$ & $23.767,88$ & $2.892,04$ & 18,79 \\
\hline 30. Productos farmacéuticos & $18.430,87$ & $38.312,56$ & $54.309,92$ & $53.878,27$ & $67.892,32$ \\
\hline 31. Abonos & 256,92 & & & 102,87 & 80,19 \\
\hline 32. Tanino, materias colorantes, pintura & $8.370,24$ & $7.995,00$ & $16.125,99$ & $14.268,78$ & $9.242,13$ \\
\hline 33. Aceites esenciales, preparac. de perfumería & 318,66 & 170,36 & 205,06 & 210,95 & 271,08 \\
\hline 34. Jabones, lubricantes, ceras & 14,69 & 122,10 & 35,62 & 55,99 & 477,07 \\
\hline 35. Materias albuminoideas, colas & 6,16 & 6,24 & 3,85 & 26,49 & 68,91 \\
\hline 36. Pólvoras y explosivos & & & & 481,07 & 311,29 \\
\hline 37. Productos fotográficos o cinematográficos & & & 4,36 & & \\
\hline 38. Otros productos químicos & 273,61 & 486,39 & 998,84 & $1.843,56$ & $2.216,19$ \\
\hline 39. Materias plásticas y sus manufacturas & 544,86 & 810,70 & $2.448,98$ & $1.388,10$ & $2.461,44$ \\
\hline 40. Caucho y sus manufacturas & $5.627,05$ & $1.754,42$ & $4.836,76$ & $6.208,35$ & $10.554,87$ \\
\hline 41. Pieles (excepto la peletería) y cueros & $2.545,26$ & $3.967,66$ & $3.353,53$ & $4.509,55$ & $2.100,29$ \\
\hline 42. Manufacturas de cuero, marroquinería & 48,48 & 42,59 & 23,17 & 199,49 & 73,18 \\
\hline 43. Peletería y sus confecciones & $1.290,32$ & 918,44 & $1.004,32$ & 435,41 & 526,66 \\
\hline 44. Madera y sus manufacturas & $14.708,83$ & $14.848,61$ & $16.466,35$ & $21.695,00$ & $19.957,96$ \\
\hline 45. Corcho y sus manufacturas & 4,93 & & 0,44 & & 35,93 \\
\hline 46. Manufacturas de cestería & 9,65 & 0,27 & & & \\
\hline 47. Pasta de madera, papel reciclado & 14,87 & 0,07 & 0,43 & 0,09 & 0,37 \\
\hline 48. Papel y cartón, sus manufacturas & 231,78 & $2.483,09$ & 707,61 & 290,04 & 663,23 \\
\hline 49. Libros, publicaciones, artes gráficas & $3.389,05$ & $2.938,77$ & $2.664,69$ & $2.360,98$ & $2.015,08$ \\
\hline
\end{tabular}


Comercio exterior de León: Exportaciones (continuación)

\begin{tabular}{|c|c|c|c|c|c|}
\hline Capítulos & 2010 & 2011 & 2012 & 2013 & 2014 \\
\hline \multicolumn{6}{|l|}{ 50. Seda } \\
\hline 51. Lana y pelo fino & 1,21 & & & & \\
\hline 52. Algodón & 2,43 & 22,17 & 3,73 & 10,06 & 414,12 \\
\hline 53. Otras fibras textiles vegetales & & & 0,51 & & \\
\hline 54. Filamentos sintéticos o artificiales & & 38,32 & 20,84 & 2,12 & 96,44 \\
\hline 55. Fibras sintéticas o artificiales discontinuas & 0,06 & 32,90 & 58,87 & 51,92 & 1,96 \\
\hline 56. Fieltro, tela sin tejer, cordelería & 4,28 & 8,08 & 6,35 & 15,39 & 8,16 \\
\hline 57. Alfombras y revestimientos textiles para el suelo & & 1,92 & & 0,26 & \\
\hline 58. Tejidos especiales, tapicería, bordados & 0,51 & & 32,02 & 0,01 & 0,72 \\
\hline 59. Tejidos recubiertos, técnicos de materias textiles & 8,49 & 0,29 & 14,48 & 0,04 & 0,04 \\
\hline 60. Tejidos de punto & & & & & 0,99 \\
\hline 61. Prendas de vestir de punto & 118,32 & 526,26 & 145,69 & $2.631,86$ & 382,72 \\
\hline 62. Prendas de vestir, excepto las de punto & $1.466,94$ & $1.733,28$ & $1.845,79$ & $5.098,26$ & $4.492,04$ \\
\hline 63. Demás artículos textiles, prendería & 21,41 & 13,14 & 19,94 & 69,04 & 119,02 \\
\hline 64. Calzado y sus partes & 34,67 & 55,64 & 63,63 & 71,41 & 102,74 \\
\hline 65. Artículos de sombrerería & 6,50 & 7,30 & 158,82 & 210,62 & 153,33 \\
\hline 66. Paraguas, sombrillas, bastones & 2,75 & 0,90 & 2,28 & 7,05 & 1,07 \\
\hline \multicolumn{6}{|l|}{ 67. Plumas y plumón preparados } \\
\hline 68. Manufacturas de piedra, yeso & $75.887,59$ & $78.306,05$ & $73.322,94$ & $65.053,04$ & $68.210,71$ \\
\hline 69. Productos cerámicos & 432,82 & 334,12 & 172,48 & 147,03 & 239,64 \\
\hline 70. Vidrio y sus manufacturas & $21.323,67$ & $28.603,21$ & $37.017,86$ & $36.572,01$ & $45.522,66$ \\
\hline 71. Piedras y metales preciosos, bisutería & 1,50 & 13,40 & 2,17 & 107,55 & 137,63 \\
\hline 72. Fundición, hierro y acero & $223.396,00$ & $166.374,59$ & $195.956,86$ & $153.144,86$ & $174.704,59$ \\
\hline 73. Manufacturas de fundición, hierro y acero & $17.971,04$ & $10.359,68$ & $15.124,08$ & $16.301,25$ & $47.124,49$ \\
\hline 74. Cobre y sus manufacturas & $23.670,27$ & $25.152,45$ & $37.008,54$ & $16.804,70$ & $9.443,32$ \\
\hline \multicolumn{6}{|l|}{ 75. Níquel y sus manufacturas } \\
\hline 76. Aluminio y sus manufacturas & $2.331,31$ & $4.889,13$ & $7.586,30$ & $3.245,56$ & $2.289,29$ \\
\hline 78. Plomo y sus manufacturas & & 73,14 & & & \\
\hline 79. Cinc y sus manufacturas & 285,06 & 290,82 & 290,83 & 226,90 & 294,09 \\
\hline 80. Estaño y sus manufacturas & & & & & 34,14 \\
\hline 81. Demás metales comunes, cermets & & & 43,55 & & 38,66 \\
\hline 82. Herramientas y cuchillos metálicos & 137,10 & 97,84 & 437,20 & 286,06 & 57,64 \\
\hline 83. Manufacturas diversas de metales & 573,98 & 529,36 & $1.071,37$ & 789,54 & $1.108,07$ \\
\hline 84. Máquinas y aparatos mecánicos & $5.888,31$ & $34.948,48$ & $27.174,29$ & $18.019,59$ & $53.885,05$ \\
\hline 85. Máquinas, aparatos y material eléctricos & $271.320,98$ & $662.459,86$ & $791.412,62$ & $534.800,44$ & $476.846,37$ \\
\hline 86. Vehículos, material ferroviarios & 23,16 & 48,29 & 3,04 & 0,56 & 214,66 \\
\hline 87. Vehículos automóviles, tractores & $9.333,66$ & $7.109,53$ & $12.696,34$ & $4.723,61$ & $3.960,11$ \\
\hline 88. Aeronaves, vehículos espaciales & 1,36 & & 1,66 & & \\
\hline \multicolumn{6}{|l|}{ 89. Barcos y embarcaciones } \\
\hline 90. Aparatos ópticos, de medida, médicos & 489,97 & 643,44 & $1.237,31$ & 604,88 & 876,56 \\
\hline 91. Relojería & 262,01 & 412,65 & 11,59 & 188,75 & 326,87 \\
\hline 92. Instrumentos musicales & & 0,94 & & 0,20 & 1,50 \\
\hline 93. Armas y municiones, accesorios & $3.075,51$ & 164,73 & 71,99 & $3.845,42$ & $3.052,26$ \\
\hline 94. Muebles, sillas, lámparas & $3.358,51$ & $2.430,81$ & $1.245,88$ & $1.058,87$ & $3.440,11$ \\
\hline 95. Juguetes, juegos, artículos deportivos & 9,54 & 14,04 & 147,02 & 55,03 & 23,34 \\
\hline 96. Manufacturas diversas & 94,88 & 52,03 & 50,10 & 7,41 & 19,51 \\
\hline 97. Objetos de arte, antigüedades & & & 1,56 & & 0,04 \\
\hline \multicolumn{6}{|l|}{ 98. Conjuntos industriales } \\
\hline 99. Conjuntos de otros productos & 564,46 & $5.653,95$ & $3.967,43$ & 251,93 & 206,97 \\
\hline TOTAL & $878.620,83$ & $1.277 .569,52$ & $1.531 .202,95$ & $1.188 .358,47$ & $1.238 .991,77$ \\
\hline
\end{tabular}




\section{J.L. PlacerGalán}

\section{Comercio exterior de León: Exportaciones (en porcentaje sobre total de exportaciones)}

\begin{tabular}{|c|c|c|c|c|c|}
\hline Capítulos & 2010 & 2011 & 2012 & 2013 & 2014 \\
\hline 01. Animales vivos & 0,3 & 0,0 & 0,5 & 0,4 & 0,2 \\
\hline 02. Carne y despojos comestibles & 2,3 & 2,0 & 2,5 & 3,2 & 3,0 \\
\hline 03. Pescados, crustáceos y moluscos & 0,2 & 0,1 & 0,1 & 0,1 & 0,1 \\
\hline 04. Leche, productos lácteos, huevos & 2,7 & 2,1 & 3,2 & 5,6 & 5,6 \\
\hline 05. Otros productos de origen animal & 0,0 & 0,0 & 0,0 & 0,0 & 0,0 \\
\hline 06. Plantas vivas y productos de floricultura & 0,0 & 0,0 & 0,0 & 0,0 & 0,0 \\
\hline 07. Legumbres, hortalizas & 1,0 & 0,6 & 0,6 & 0,8 & 0,5 \\
\hline 08. Frutos comestibles & 0,1 & 0,0 & 0,1 & 0,4 & 0,5 \\
\hline 09. Café, té, yerba mate y especias & 0,1 & 0,0 & 0,0 & 0,1 & 0,0 \\
\hline 10. Cereales & 0,4 & 0,4 & 0,4 & 0,6 & 0,6 \\
\hline 11. Productos de la molinería, malta & 0,0 & 0,0 & 0,0 & 0,0 & 0,0 \\
\hline 12. Semillas y frutos oleaginosos & 0,6 & 0,4 & 0,3 & 0,5 & 0,7 \\
\hline 13. Jugos y extractos vegetales & 0,0 & 0,0 & 0,0 & 0,0 & 0,0 \\
\hline 14. Materias trenzables & 0,0 & 0,0 & 0,0 & 0,0 & 0,0 \\
\hline 15. Grasas, aceite animal y vegetal & 0,0 & 0,0 & 0,0 & 0,0 & 0,0 \\
\hline 16. Conservas de carne o pescado & 0,3 & 0,2 & 0,2 & 0,3 & 0,3 \\
\hline 17. Azúcares, artículos de confitería & 0,1 & 0,7 & 1,3 & 2,0 & 1,8 \\
\hline 18. Cacao y sus preparaciones & 0,0 & 0,0 & 0,0 & 0,0 & 0,0 \\
\hline 19. Productos de cereales, de pastelería & 0,2 & 0,1 & 0,0 & 0,0 & 0,0 \\
\hline 20. Conservas de verdura o fruta, zumo & 0,2 & 0,2 & 0,2 & 0,3 & 0,3 \\
\hline 21. Preparaciones alimenticias diversas & 2,9 & 1,9 & 1,4 & 1,6 & 1,4 \\
\hline 22. Bebidas de todo tipo (excluidos zumos) & 0,5 & 0,4 & 0,5 & 0,7 & 0,8 \\
\hline 23. Residuos de la industria alimentaria & 1,0 & 0,8 & 0,6 & 0,6 & 1,2 \\
\hline 24. Tabaco y sus sucedáneos & 0,0 & 0,0 & 0,0 & 0,0 & 0,0 \\
\hline 25. Sal, yeso piedras sin trabajar & 0,4 & 0,3 & 0,1 & 0,1 & 0,2 \\
\hline 26. Minerales, escorias y cenizas & 0,0 & 0,2 & 0,3 & 0,2 & 0,2 \\
\hline 27. Combustibles, aceites minerales & 1,1 & 0,6 & 0,4 & 0,4 & 0,4 \\
\hline 28. Productos químicos inorgánicos & 0,0 & 0,0 & 0,0 & 0,0 & 0,0 \\
\hline 29. Productos químicos orgánicos & 3,9 & 2,0 & 1,6 & 0,2 & 0,0 \\
\hline 30. Productos farmacéuticos & 2,1 & 3,0 & 3,5 & 4,5 & 5,5 \\
\hline 31. Abonos & 0,0 & 0,0 & 0,0 & 0,0 & 0,0 \\
\hline 32. Tanino, materias colorantes, pintura & 1,0 & 0,6 & 1,1 & 1,2 & 0,7 \\
\hline 33. Aceites esenciales, preparac. de perfumería & 0,0 & 0,0 & 0,0 & 0,0 & 0,0 \\
\hline 34. Jabones, lubricantes, ceras & 0,0 & 0,0 & 0,0 & 0,0 & 0,0 \\
\hline 35. Materias albuminoideas, colas & 0,0 & 0,0 & 0,0 & 0,0 & 0,0 \\
\hline 36. Pólvoras y explosivos & 0,0 & 0,0 & 0,0 & 0,0 & 0,0 \\
\hline 37. Productos fotográficos o cinematográficos & 0,0 & 0,0 & 0,0 & 0,0 & 0,0 \\
\hline 38. Otros productos químicos & 0,0 & 0,0 & 0,1 & 0,2 & 0,2 \\
\hline 39. Materias plásticas y sus manufacturas & 0,1 & 0,1 & 0,2 & 0,1 & 0,2 \\
\hline 40. Caucho y sus manufacturas & 0,6 & 0,1 & 0,3 & 0,5 & 0,9 \\
\hline 41. Pieles (excepto la peletería) y cueros & 0,3 & 0,3 & 0,2 & 0,4 & 0,2 \\
\hline 42. Manufacturas de cuero, marroquinería & 0,0 & 0,0 & 0,0 & 0,0 & 0,0 \\
\hline 43. Peletería y sus confecciones & 0,1 & 0,1 & 0,1 & 0,0 & 0,0 \\
\hline 44. Madera y sus manufacturas & 1,7 & 1,2 & 1,1 & 1,8 & 1,6 \\
\hline 45. Corcho y sus manufacturas & 0,0 & 0,0 & 0,0 & 0,0 & 0,0 \\
\hline 46. Manufacturas de cestería & 0,0 & 0,0 & 0,0 & 0,0 & 0,0 \\
\hline 47. Pasta de madera, papel reciclado & 0,0 & 0,0 & 0,0 & 0,0 & 0,0 \\
\hline 48. Papel y cartón, sus manufacturas & 0,0 & 0,2 & 0,0 & 0,0 & 0,1 \\
\hline 49. Libros, publicaciones, artes gráficas & 0,4 & 0,2 & 0,2 & 0,2 & 0,2 \\
\hline
\end{tabular}




\section{Comercio exterior de León: Exportaciones (cont.)}

\begin{tabular}{|c|c|c|c|c|c|}
\hline Capítulos & 2010 & 2011 & 2012 & 2013 & 2014 \\
\hline 50. Seda & 0,0 & 0,0 & 0,0 & 0,0 & 0,0 \\
\hline 51. Lana y pelo fino & 0,0 & 0,0 & 0,0 & 0,0 & 0,0 \\
\hline 52. Algodón & 0,0 & 0,0 & 0,0 & 0,0 & 0,0 \\
\hline 53. Otras fibras textiles vegetales & 0,0 & 0,0 & 0,0 & 0,0 & 0,0 \\
\hline 54. Filamentos sintéticos o artificiales & 0,0 & 0,0 & 0,0 & 0,0 & 0,0 \\
\hline 55. Fibras sintéticas o artificiales discontinuas & 0,0 & 0,0 & 0,0 & 0,0 & 0,0 \\
\hline 56. Fieltro, tela sin tejer, cordelería & 0,0 & 0,0 & 0,0 & 0,0 & 0,0 \\
\hline 57. Alfombras y revestimientos textiles para el suelo & 0,0 & 0,0 & 0,0 & 0,0 & 0,0 \\
\hline 58. Tejidos especiales, tapicería, bordados & 0,0 & 0,0 & 0,0 & 0,0 & 0,0 \\
\hline 59. Tejidos recubiertos, técnicos de materias textiles & 0,0 & 0,0 & 0,0 & 0,0 & 0,0 \\
\hline 60. Tejidos de punto & 0,0 & 0,0 & 0,0 & 0,0 & 0,0 \\
\hline 61. Prendas de vestir de punto & 0,0 & 0,0 & 0,0 & 0,2 & 0,0 \\
\hline 62. Prendas de vestir, excepto las de punto & 0,2 & 0,1 & 0,1 & 0,4 & 0,4 \\
\hline 63. Demás artículos textiles, prendería & 0,0 & 0,0 & 0,0 & 0,0 & 0,0 \\
\hline 64. Calzado y sus partes & 0,0 & 0,0 & 0,0 & 0,0 & 0,0 \\
\hline 65. Artículos de sombrerería & 0,0 & 0,0 & 0,0 & 0,0 & 0,0 \\
\hline 66. Paraguas, sombrillas, bastones & 0,0 & 0,0 & 0,0 & 0,0 & 0,0 \\
\hline 67. Plumas y plumón preparados & 0,0 & 0,0 & 0,0 & 0,0 & 0,0 \\
\hline 68. Manufacturas de piedra, yeso & 8,6 & 6,1 & 4,8 & 5,5 & 5,5 \\
\hline 69. Productos cerámicos & 0,0 & 0,0 & 0,0 & 0,0 & 0,0 \\
\hline 70. Vidrio y sus manufacturas & 2,4 & 2,2 & 2,4 & 3,1 & 3,7 \\
\hline 71. Piedras y metales preciosos, bisutería & 0,0 & 0,0 & 0,0 & 0,0 & 0,0 \\
\hline 72. Fundición, hierro y acero & 25,4 & 13,0 & 12,8 & 12,9 & 14,1 \\
\hline 73. Manufacturas de fundición, hierro y acero & 2,0 & 0,8 & 1,0 & 1,4 & 3,8 \\
\hline 74. Cobre y sus manufacturas & 2,7 & 2,0 & 2,4 & 1,4 & 0,8 \\
\hline 75. Níquel y sus manufacturas & 0,0 & 0,0 & 0,0 & 0,0 & 0,0 \\
\hline 76. Aluminio y sus manufacturas & 0,3 & 0,4 & 0,5 & 0,3 & 0,2 \\
\hline 78. Plomo y sus manufacturas & 0,0 & 0,0 & 0,0 & 0,0 & 0,0 \\
\hline 79. Cinc y sus manufacturas & 0,0 & 0,0 & 0,0 & 0,0 & 0,0 \\
\hline 80. Estaño y sus manufacturas & 0,0 & 0,0 & 0,0 & 0,0 & 0,0 \\
\hline 81. Demás metales comunes, cermets & 0,0 & 0,0 & 0,0 & 0,0 & 0,0 \\
\hline 82. Herramientas y cuchillos metálicos & 0,0 & 0,0 & 0,0 & 0,0 & 0,0 \\
\hline 83. Manufacturas diversas de metales & 0,1 & 0,0 & 0,1 & 0,1 & 0,1 \\
\hline 84. Máquinas y aparatos mecánicos & 0,7 & 2,7 & 1,8 & 1,5 & 4,3 \\
\hline 85. Máquinas, aparatos y material eléctricos & 30,9 & 51,9 & 51,7 & 45,0 & 38,5 \\
\hline 86. Vehículos, material ferroviarios & 0,0 & 0,0 & 0,0 & 0,0 & 0,0 \\
\hline 87. Vehículos automóviles, tractores & 1,1 & 0,6 & 0,8 & 0,4 & 0,3 \\
\hline 88. Aeronaves, vehículos espaciales & 0,0 & 0,0 & 0,0 & 0,0 & 0,0 \\
\hline 89. Barcos y embarcaciones & 0,0 & 0,0 & 0,0 & 0,0 & 0,0 \\
\hline 90. Aparatos ópticos, de medida, médicos & 0,1 & 0,1 & 0,1 & 0,1 & 0,1 \\
\hline 91. Relojería & 0,0 & 0,0 & 0,0 & 0,0 & 0,0 \\
\hline 92. Instrumentos musicales & 0,0 & 0,0 & 0,0 & 0,0 & 0,0 \\
\hline 93. Armas y municiones, accesorios & 0,4 & 0,0 & 0,0 & 0,3 & 0,2 \\
\hline 94. Muebles, sillas, lámparas & 0,4 & 0,2 & 0,1 & 0,1 & 0,3 \\
\hline 95. Juguetes, juegos, artículos deportivos & 0,0 & 0,0 & 0,0 & 0,0 & 0,0 \\
\hline 96. Manufacturas diversas & 0,0 & 0,0 & 0,0 & 0,0 & 0,0 \\
\hline 97. Objetos de arte, antigüedades & 0,0 & 0,0 & 0,0 & 0,0 & 0,0 \\
\hline 98. Conjuntos industriales & 0,0 & 0,0 & 0,0 & 0,0 & 0,0 \\
\hline 99. Conjuntos de otros productos & 0,1 & 0,4 & 0,3 & 0,0 & 0,0 \\
\hline TOTAL & 100,0 & 100,0 & 100,0 & 100,0 & 100,0 \\
\hline
\end{tabular}




\section{J.L. Placer Galán}

\section{Comercio exterior de León: Importaciones (en miles de euros)}

\begin{tabular}{|c|c|c|c|c|c|}
\hline Capítulos & 2010 & 2011 & 2012 & 2013 & 2014 \\
\hline 01. Animales vivos & $6.767,37$ & $3.979,62$ & $4.760,14$ & $3.149,94$ & $3.869,63$ \\
\hline 02. Carne y despojos comestibles & $3.019,83$ & $3.879,71$ & $3.335,39$ & $2.135,52$ & $2.184,31$ \\
\hline 03. Pescados, crustáceos y moluscos & $22.973,00$ & $19.063,64$ & $13.988,89$ & $12.106,50$ & $13.016,95$ \\
\hline 04. Leche, productos lácteos, huevos & $8.275,41$ & $14.064,37$ & $11.641,82$ & $11.210,30$ & $14.269,58$ \\
\hline 05. Otros productos de origen animal & 303,01 & 600,7 & 557,24 & 473,45 & 480,23 \\
\hline 06. Plantas vivas y productos de floricultura & 353,22 & 387,35 & 330,24 & 279,24 & 271,48 \\
\hline 07. Legumbres, hortalizas & $75.328,64$ & $67.161,79$ & $88.319,12$ & $85.988,09$ & $68.726,76$ \\
\hline 08. Frutos comestibles & $1.669,68$ & $1.714,74$ & $2.096,21$ & $2.902,62$ & $3.200,14$ \\
\hline 09. Café, té, yerba mate y especias & 596,12 & 696,86 & 973,86 & 814,95 & $1.184,61$ \\
\hline 10. Cereales & $24.995,05$ & $29.407,96$ & $33.805,13$ & $4.065,02$ & $12.368,63$ \\
\hline 11. Productos de la molinería, malta & & 287,24 & $3.268,68$ & 725,69 & 508,92 \\
\hline 12. Semillas y frutos oleaginosos & $8.224,04$ & $8.451,73$ & $9.953,21$ & $10.337,65$ & $12.871,74$ \\
\hline 13. Jugos y extractos vegetales & 167,4 & 186,6 & 366,43 & 281,26 & $1.153,54$ \\
\hline 14. Materias trenzables & - & 6,1 & - & 0,23 & 17,27 \\
\hline 15. Grasas, aceite animal y vegetal & $2.443,72$ & $2.569,13$ & 691,33 & 966,79 & $2.206,23$ \\
\hline 16. Conservas de carne o pescado & 559,39 & 435,08 & 405,8 & 124,41 & 646,26 \\
\hline 17. Azúcares, artículos de confitería & 329,31 & 976,51 & $2.332,06$ & $9.300,42$ & $14.304,74$ \\
\hline 18. Cacao y sus preparaciones & 7,51 & 713,38 & 178,58 & $1.434,32$ & 408,54 \\
\hline 19. Productos de cereales, de pastelería & 642,17 & 530,15 & $1.608,69$ & $1.573,34$ & $3.383,48$ \\
\hline 20. Conservas de verdura o fruta, zumo & $2.781,40$ & $3.583,74$ & $2.959,59$ & $4.630,27$ & $4.943,77$ \\
\hline 21. Preparaciones alimenticias diversas & 441,87 & 324,02 & 712,94 & 364,24 & 864,73 \\
\hline 22. Bebidas de todo tipo (excluidos zumos) & 47,5 & 217,19 & 357,41 & 320,85 & $2.321,08$ \\
\hline 23. Residuos de la industria alimentaria & $6.557,37$ & $6.363,55$ & $5.351,64$ & $5.036,44$ & $6.200,96$ \\
\hline 24. Tabaco y sus sucedáneos & - & - & - & - & \\
\hline 25. Sal, yeso piedras sin trabajar & 822,28 & $1.151,53$ & 605,59 & 213,1 & 316,68 \\
\hline 26. Minerales, escorias y cenizas & 48,79 & 296,26 & 125,32 & 60,25 & 154,53 \\
\hline 27. Combustibles, aceites minerales & $1.702,10$ & $20.574,08$ & $1.627,93$ & $4.595,32$ & $6.723,44$ \\
\hline 28. Productos químicos inorgánicos & $12.269,69$ & $9.038,32$ & $2.380,20$ & 974,43 & 855,74 \\
\hline 29. Productos químicos orgánicos & $16.622,46$ & $20.526,99$ & $21.722,14$ & $11.657,41$ & $14.792,87$ \\
\hline 30. Productos farmacéuticos & $2.116,63$ & $1.444,17$ & $2.192,12$ & $1.706,37$ & $2.091,87$ \\
\hline 31. Abonos & $8.638,42$ & $7.195,87$ & $9.512,29$ & $6.855,58$ & $5.269,42$ \\
\hline 32. Tanino, materias colorantes, pintura & $4.087,96$ & $7.003,68$ & $6.132,56$ & $7.286,74$ & $5.789,46$ \\
\hline 33. Aceites esenciales, preparac. de perfumería & 521,85 & 981,85 & 553,42 & 592,2 & $1.436,58$ \\
\hline 34. Jabones, lubricantes, ceras & 578 & 362,31 & 145,54 & 128,23 & 503,46 \\
\hline 35. Materias albuminoideas, colas & $1.187,53$ & 896,5 & $1.229,43$ & $1.015,35$ & $1.035,83$ \\
\hline 36. Pólvoras y explosivos & 711,38 & 14,27 & 25,17 & $4.535,87$ & $9.748,55$ \\
\hline 37. Productos fotográficos o cinematográficos & 9,4 & 0,22 & 0,43 & 0,04 & 1,28 \\
\hline 38. Otros productos químicos & $1.719,56$ & $4.554,14$ & $1.972,00$ & $2.061,30$ & $2.070,88$ \\
\hline 39. Materias plásticas y sus manufacturas & $13.593,10$ & $17.191,89$ & $16.652,60$ & $19.824,00$ & $20.134,34$ \\
\hline 40. Caucho y sus manufacturas & $3.613,93$ & $3.712,46$ & $2.719,96$ & $2.329,20$ & $2.569,00$ \\
\hline 41. Pieles (excepto la peletería) y cueros & $1.075,33$ & $1.174,99$ & $1.248,00$ & $1.471,08$ & 709,72 \\
\hline 42. Manufacturas de cuero, marroquinería & $1.488,05$ & $3.260,28$ & 780,67 & $3.532,53$ & $2.107,78$ \\
\hline 43. Peletería y sus confecciones & 213,24 & 322,18 & 223,68 & 119,22 & 95,09 \\
\hline 44. Madera y sus manufacturas & $4.101,52$ & $3.851,88$ & $3.144,97$ & $3.336,57$ & $5.192,80$ \\
\hline 45. Corcho y sus manufacturas & 106,99 & 104,6 & 363,31 & 165,09 & 238,66 \\
\hline 46. Manufacturas de cestería & 0,97 & 33,7 & 0,72 & 5,46 & 7,7 \\
\hline 47. Pasta de madera, papel reciclado & 32,24 & 1,33 & 4,87 & 17,93 & 37,23 \\
\hline 48. Papel y cartón, sus manufacturas & $3.545,19$ & $4.313,61$ & $4.814,81$ & $3.180,22$ & $5.506,62$ \\
\hline 49. Libros, publicaciones, artes gráficas & 822,46 & 464,11 & 697,9 & 453,07 & 208,3 \\
\hline
\end{tabular}


Comercio exterior de León: Importaciones (cont.)

\begin{tabular}{|c|c|c|c|c|c|}
\hline Capítulos & 2010 & 2011 & 2012 & 2013 & 2014 \\
\hline 50. Seda & - & - & 2,58 & 8,13 & 8,57 \\
\hline 51. Lana y pelo fino & 1 & - & - & - & 5,52 \\
\hline 52. Algodón & 66,59 & 55,09 & 54,19 & 284,66 & 357,66 \\
\hline 53. Otras fibras textiles vegetales & 5,55 & - & - & 0,11 & 0,16 \\
\hline 54. Filamentos sintéticos o artificiales & 28,42 & 43,91 & 51,38 & 57,15 & 148,02 \\
\hline 55. Fibras sintéticas o artificiales discontinuas & 170,02 & 253,51 & 223,24 & 261,98 & 140,63 \\
\hline 56. Fieltro, tela sin tejer, cordelería & 162,66 & 131,22 & 182,2 & 66,67 & 49,15 \\
\hline 57. Alfombras y revestimientos textiles para el suelo & 249,66 & 63,14 & 49,14 & 62,5 & 40,15 \\
\hline 58. Tejidos especiales, tapicería, bordados & 9,65 & 17,96 & 21,63 & 15,79 & 5,6 \\
\hline 59. Tejidos recubiertos, técnicos de materias textiles & 121,8 & 82,29 & 229,85 & 87,97 & 44,59 \\
\hline 60. Tejidos de punto & 6,95 & 28,68 & 55,96 & 0,14 & 4,58 \\
\hline 61. Prendas de vestir de punto & $3.591,85$ & $3.588,00$ & $3.401,37$ & $3.006,49$ & $3.095,11$ \\
\hline 62. Prendas de vestir, excepto las de punto & $5.762,63$ & $6.972,77$ & $5.821,78$ & $5.994,87$ & $6.851,65$ \\
\hline 63. Demás artículos textiles, prendería & 603,37 & 189,44 & 166,54 & 203,36 & 204,36 \\
\hline 64. Calzado y sus partes & $2.257,09$ & $1.812,11$ & $1.368,51$ & $1.041,62$ & $1.309,87$ \\
\hline 65. Artículos de sombrerería & 98,61 & 130,2 & 101,24 & 97,07 & 122,66 \\
\hline 66. Paraguas, sombrillas, bastones & 13,15 & 24,39 & 7,38 & 11,44 & 20,51 \\
\hline 67. Plumas y plumón preparados & 25,86 & 47,47 & 48,36 & 33,28 & 29,26 \\
\hline 68. Manufacturas de piedra, yeso & $2.279,32$ & $2.577,18$ & $4.416,70$ & $3.638,61$ & $3.990,41$ \\
\hline 69. Productos cerámicos & $2.872,51$ & $2.460,59$ & $1.582,87$ & $1.883,54$ & $2.323,26$ \\
\hline 70. Vidrio y sus manufacturas & $7.039,47$ & $13.345,02$ & $11.141,94$ & $11.389,13$ & $15.647,54$ \\
\hline 71. Piedras y metales preciosos, bisutería & 481,74 & 510,43 & 397,21 & 410,09 & 455,83 \\
\hline 72. Fundición, hierro y acero & $1.872,45$ & $18.779,06$ & $2.224,14$ & $2.484,37$ & $1.832,76$ \\
\hline 73. Manufacturas de fundición, hierro y acero & $3.298,76$ & $4.962,46$ & $5.249,43$ & $10.092,47$ & $6.377,21$ \\
\hline 74. Cobre y sus manufacturas & $16.117,03$ & $19.427,45$ & $31.168,18$ & $19.283,44$ & $17.869,90$ \\
\hline 75. Níquel y sus manufacturas & 0,95 & 0,91 & 0,98 & 14,47 & 0,8 \\
\hline 76. Aluminio y sus manufacturas & $3.552,64$ & $4.184,46$ & $5.003,11$ & $4.915,11$ & $5.427,03$ \\
\hline 78. Plomo y sus manufacturas & 37,78 & - & - & - & - \\
\hline 79. Cinc y sus manufacturas & 218,58 & 24,79 & 196,32 & 254,27 & 360,14 \\
\hline 80. Estaño y sus manufacturas & 1,5 & 9,33 & 1,38 & 0,52 & 520,56 \\
\hline 81. Demás metales comunes, cermets & 117,35 & 181,93 & 94,42 & 11,86 & 29,14 \\
\hline 82. Herramientas y cuchillos metálicos & $1.040,94$ & $1.133,02$ & 790,08 & 494,91 & 955,54 \\
\hline 83. Manufacturas diversas de metales & 211,67 & 134,34 & 192,72 & 264,91 & 343,78 \\
\hline 84. Máquinas y aparatos mecánicos & $77.195,46$ & $24.903,44$ & $21.631,63$ & $23.092,84$ & $30.343,62$ \\
\hline 85. Máquinas, aparatos y material eléctricos & $35.839,96$ & $9.283,32$ & $5.709,15$ & $22.749,49$ & $14.280,29$ \\
\hline 86. Vehículos, material ferroviarios & 469,68 & 658,92 & 451,71 & 243,18 & 252,37 \\
\hline 87. Vehículos automóviles, tractores & $12.075,77$ & $11.126,08$ & $7.782,14$ & $9.742,98$ & $14.559,54$ \\
\hline 88. Aeronaves, vehículos espaciales & - & 19,1 & 59,23 & - & 2,1 \\
\hline 89. Barcos y embarcaciones & - & - & - & 0,88 & 6,63 \\
\hline 90. Aparatos ópticos, de medida, médicos & $3.980,77$ & $3.919,09$ & $4.791,83$ & $4.760,58$ & $5.889,23$ \\
\hline 91. Relojería & 316,06 & 368,23 & 415,44 & 589,57 & 403,34 \\
\hline 92. Instrumentos musicales & 8,76 & 9,93 & 7,24 & $1.231,55$ & 5,39 \\
\hline 93. Armas y municiones, accesorios & $7.205,35$ & $5.376,44$ & $5.225,63$ & $6.411,26$ & $6.472,27$ \\
\hline 94. Muebles, sillas, lámparas & $2.671,90$ & $1.664,53$ & $1.345,28$ & $1.091,64$ & $1.407,39$ \\
\hline 95. Juguetes, juegos, artículos deportivos & 240,34 & 312,5 & 163,65 & 212,02 & 207,41 \\
\hline 96. Manufacturas diversas & 270,18 & 374,1 & 313,34 & 276,63 & 337,19 \\
\hline 97. Objetos de arte, antigüedades & 24,85 & 6,02 & 8,2 & 2,57 & 5,07 \\
\hline 98. Conjuntos industriales & - & - & - & - & - \\
\hline 99. Conjuntos de otros productos & $6.238,49$ & $7.521,61$ & $6.283,80$ & 340,44 & 595,05 \\
\hline TOTAL & $444.967,25$ & $420.786,83$ & $395.303,14$ & $371.454,69$ & $400.340,32$ \\
\hline
\end{tabular}




\section{J .L. Placer Galán}

\section{Comercio exterior de León: Importaciones (en porcentaje sobre total de importaciones)}

\begin{tabular}{|c|c|c|c|c|c|}
\hline Capítulos & 2010 & 2011 & 2012 & 2013 & 2014 \\
\hline 01. Animales vivos & 1,5 & 0,9 & 1,2 & 0,8 & 1,0 \\
\hline 02. Carne y despojos comestibles & 0,7 & 0,9 & 0,8 & 0,6 & 0,5 \\
\hline 03. Pescados, crustáceos y moluscos & 5,2 & 4,5 & 3,5 & 3,3 & 3,3 \\
\hline 04. Leche, productos lácteos, huevos & 1,9 & 3,3 & 2,9 & 3,0 & 3,6 \\
\hline 05. Otros productos de origen animal & 0,1 & 0,1 & 0,1 & 0,1 & 0,1 \\
\hline 06. Plantas vivas y productos de floricultura & 0,1 & 0,1 & 0,1 & 0,1 & 0,1 \\
\hline 07. Legumbres, hortalizas & 16,9 & 16,0 & 22,3 & 23,1 & 17,2 \\
\hline 08. Frutos comestibles & 0,4 & 0,4 & 0,5 & 0,8 & 0,8 \\
\hline 09. Café, té, yerba mate y especias & 0,1 & 0,2 & 0,2 & 0,2 & 0,3 \\
\hline 10. Cereales & 5,6 & 7,0 & 8,6 & 1,1 & 3,1 \\
\hline 11. Productos de la molinería, malta & 0,0 & 0,1 & 0,8 & 0,2 & 0,1 \\
\hline 12. Semillas y frutos oleaginosos & 1,8 & 2,0 & 2,5 & 2,8 & 3,2 \\
\hline 13. Jugos y extractos vegetales & 0,0 & 0,0 & 0,1 & 0,1 & 0,3 \\
\hline 14. Materias trenzables & 0,0 & 0,0 & 0,0 & 0,0 & 0,0 \\
\hline 15. Grasas, aceite animal y vegetal & 0,5 & 0,6 & 0,2 & 0,3 & 0,6 \\
\hline 16. Conservas de carne o pescado & 0,1 & 0,1 & 0,1 & 0,0 & 0,2 \\
\hline 17. Azúcares, artículos de confitería & 0,1 & 0,2 & 0,6 & 2,5 & 3,6 \\
\hline 18. Cacao y sus preparaciones & 0,0 & 0,2 & 0,0 & 0,4 & 0,1 \\
\hline 19. Productos de cereales, de pastelería & 0,1 & 0,1 & 0,4 & 0,4 & 0,8 \\
\hline 20. Conservas de verdura o fruta, zumo & 0,6 & 0,9 & 0,7 & 1,2 & 1,2 \\
\hline 21. Preparaciones alimenticias diversas & 0,1 & 0,1 & 0,2 & 0,1 & 0,2 \\
\hline 22. Bebidas de todo tipo (excluidos zumos) & 0,0 & 0,1 & 0,1 & 0,1 & 0,6 \\
\hline 23. Residuos de la industria alimentaria & 1,5 & 1,5 & 1,4 & 1,4 & 1,5 \\
\hline 24. Tabaco y sus sucedáneos & 0,0 & 0,0 & 0,0 & 0,0 & 0,0 \\
\hline 25. Sal, yeso piedras sin trabajar & 0,2 & 0,3 & 0,2 & 0,1 & 0,1 \\
\hline 26. Minerales, escorias y cenizas & 0,0 & 0,1 & 0,0 & 0,0 & 0,0 \\
\hline 27. Combustibles, aceites minerales & 0,4 & 4,9 & 0,4 & 1,2 & 1,7 \\
\hline 28. Productos químicos inorgánicos & 2,8 & 2,1 & 0,6 & 0,3 & 0,2 \\
\hline 29. Productos químicos orgánicos & 3,7 & 4,9 & 5,5 & 3,1 & 3,7 \\
\hline 30. Productos farmacéuticos & 0,5 & 0,3 & 0,6 & 0,5 & 0,5 \\
\hline 31. Abonos & 1,9 & 1,7 & 2,4 & 1,8 & 1,3 \\
\hline 32. Tanino, materias colorantes, pintura & 0,9 & 1,7 & 1,6 & 2,0 & 1,4 \\
\hline 33. Aceites esenciales, preparac. de perfumería & 0,1 & 0,2 & 0,1 & 0,2 & 0,4 \\
\hline 34. Jabones, lubricantes, ceras & 0,1 & 0,1 & 0,0 & 0,0 & 0,1 \\
\hline 35. Materias albuminoideas, colas & 0,3 & 0,2 & 0,3 & 0,3 & 0,3 \\
\hline 36. Pólvoras y explosivos & 0,2 & 0,0 & 0,0 & 1,2 & 2,4 \\
\hline 37. Productos fotográficos o cinematográficos & 0,0 & 0,0 & 0,0 & 0,0 & 0,0 \\
\hline 38. Otros productos químicos & 0,4 & 1,1 & 0,5 & 0,6 & 0,5 \\
\hline 39. Materias plásticas y sus manufacturas & 3,1 & 4,1 & 4,2 & 5,3 & 5,0 \\
\hline 40. Caucho y sus manufacturas & 0,8 & 0,9 & 0,7 & 0,6 & 0,6 \\
\hline 41. Pieles (excepto la peletería) y cueros & 0,2 & 0,3 & 0,3 & 0,4 & 0,2 \\
\hline 42. Manufacturas de cuero, marroquinería & 0,3 & 0,8 & 0,2 & 1,0 & 0,5 \\
\hline 43. Peletería y sus confecciones & 0,0 & 0,1 & 0,1 & 0,0 & 0,0 \\
\hline 44. Madera y sus manufacturas & 0,9 & 0,9 & 0,8 & 0,9 & 1,3 \\
\hline 45. Corcho y sus manufacturas & 0,0 & 0,0 & 0,1 & 0,0 & 0,1 \\
\hline 46. Manufacturas de cestería & 0,0 & 0,0 & 0,0 & 0,0 & 0,0 \\
\hline 47. Pasta de madera, papel reciclado & 0,0 & 0,0 & 0,0 & 0,0 & 0,0 \\
\hline 48. Papel y cartón, sus manufacturas & 0,8 & 1,0 & 1,2 & 0,9 & 1,4 \\
\hline 49. Libros, publicaciones, artes gráficas & 0,2 & 0,1 & 0,2 & 0,1 & 0,1 \\
\hline
\end{tabular}


Comercio exterior de León: importaciones (cont.)

\begin{tabular}{|c|c|c|c|c|c|}
\hline Capítulos & 2010 & 2011 & 2012 & 2013 & 2014 \\
\hline 50. Seda & 0,0 & 0,0 & 0,0 & 0,0 & 0,0 \\
\hline 51. Lana y pelo fino & 0,0 & 0,0 & 0,0 & 0,0 & 0,0 \\
\hline 52. Algodón & 0,0 & 0,0 & 0,0 & 0,1 & 0,1 \\
\hline 53. Otras fibras textiles vegetales & 0,0 & 0,0 & 0,0 & 0,0 & 0,0 \\
\hline 54. Filamentos sintéticos o artificiales & 0,0 & 0,0 & 0,0 & 0,0 & 0,0 \\
\hline 55. Fibras sintéticas o artificiales discontinuas & 0,0 & 0,1 & 0,1 & 0,1 & 0,0 \\
\hline 56. Fieltro, tela sin tejer, cordelería & 0,0 & 0,0 & 0,0 & 0,0 & 0,0 \\
\hline 57. Alfombras y revestimientos textiles para el suelo & 0,1 & 0,0 & 0,0 & 0,0 & 0,0 \\
\hline 58. Tejidos especiales, tapicería, bordados & 0,0 & 0,0 & 0,0 & 0,0 & 0,0 \\
\hline 59. Tejidos recubiertos, técnicos de materias textiles & 0,0 & 0,0 & 0,1 & 0,0 & 0,0 \\
\hline 60. Tejidos de punto & 0,0 & 0,0 & 0,0 & 0,0 & 0,0 \\
\hline 61. Prendas de vestir de punto & 0,8 & 0,9 & 0,9 & 0,8 & 0,8 \\
\hline 62. Prendas de vestir, excepto las de punto & 1,3 & 1,7 & 1,5 & 1,6 & 1,7 \\
\hline 63. Demás artículos textiles, prendería & 0,1 & 0,0 & 0,0 & 0,1 & 0,1 \\
\hline 64. Calzado y sus partes & 0,5 & 0,4 & 0,3 & 0,3 & 0,3 \\
\hline 65. Artículos de sombrerería & 0,0 & 0,0 & 0,0 & 0,0 & 0,0 \\
\hline 66. Paraguas, sombrillas, bastones & 0,0 & 0,0 & 0,0 & 0,0 & 0,0 \\
\hline 67. Plumas y plumón preparados & 0,0 & 0,0 & 0,0 & 0,0 & 0,0 \\
\hline 68. Manufacturas de piedra, yeso & 0,5 & 0,6 & 1,1 & 1,0 & 1,0 \\
\hline 69. Productos cerámicos & 0,6 & 0,6 & 0,4 & 0,5 & 0,6 \\
\hline 70. Vidrio y sus manufacturas & 1,6 & 3,2 & 2,8 & 3,1 & 3,9 \\
\hline 71. Piedras y metales preciosos, bisutería & 0,1 & 0,1 & 0,1 & 0,1 & 0,1 \\
\hline 72. Fundición, hierro y acero & 0,4 & 4,5 & 0,6 & 0,7 & 0,5 \\
\hline 73. Manufacturas de fundición, hierro y acero & 0,7 & 1,2 & 1,3 & 2,7 & 1,6 \\
\hline 74. Cobre y sus manufacturas & 3,6 & 4,6 & 7,9 & 5,2 & 4,5 \\
\hline 75. Níquel y sus manufacturas & 0,0 & 0,0 & 0,0 & 0,0 & 0,0 \\
\hline 76. Aluminio y sus manufacturas & 0,8 & 1,0 & 1,3 & 1,3 & 1,4 \\
\hline 78. Plomo y sus manufacturas & 0,0 & 0,0 & 0,0 & 0,0 & 0,0 \\
\hline 79. Cinc y sus manufacturas & 0,0 & 0,0 & 0,0 & 0,1 & 0,1 \\
\hline 80. Estaño y sus manufacturas & 0,0 & 0,0 & 0,0 & 0,0 & 0,1 \\
\hline 81. Demás metales comunes, cermets & 0,0 & 0,0 & 0,0 & 0,0 & 0,0 \\
\hline 82. Herramientas y cuchillos metálicos & 0,2 & 0,3 & 0,2 & 0,1 & 0,2 \\
\hline 83. Manufacturas diversas de metales & 0,0 & 0,0 & 0,0 & 0,1 & 0,1 \\
\hline 84. Máquinas y aparatos mecánicos & 17,3 & 5,9 & 5,5 & 6,2 & 7,6 \\
\hline 85. Máquinas, aparatos y material eléctricos & 8,1 & 2,2 & 1,4 & 6,1 & 3,6 \\
\hline 86. Vehículos, material ferroviarios & 0,1 & 0,2 & 0,1 & 0,1 & 0,1 \\
\hline 87. Vehículos automóviles, tractores & 2,7 & 2,6 & 2,0 & 2,6 & 3,6 \\
\hline 88. Aeronaves, vehículos espaciales & 0,0 & 0,0 & 0,0 & 0,0 & 0,0 \\
\hline 89. Barcos y embarcaciones & 0,0 & 0,0 & 0,0 & 0,0 & 0,0 \\
\hline 90. Aparatos ópticos, de medida, médicos & 0,9 & 0,9 & 1,2 & 1,3 & 1,5 \\
\hline 91. Relojería & 0,1 & 0,1 & 0,1 & 0,2 & 0,1 \\
\hline 92. Instrumentos musicales & 0,0 & 0,0 & 0,0 & 0,3 & 0,0 \\
\hline 93. Armas y municiones, accesorios & 1,6 & 1,3 & 1,3 & 1,7 & 1,6 \\
\hline 94. Muebles, sillas, lámparas & 0,6 & 0,4 & 0,3 & 0,3 & 0,4 \\
\hline 95. Juguetes, juegos, artículos deportivos & 0,1 & 0,1 & 0,0 & 0,1 & 0,1 \\
\hline 96. Manufacturas diversas & 0,1 & 0,1 & 0,1 & 0,1 & 0,1 \\
\hline 97. Objetos de arte, antigüedades & 0,0 & 0,0 & 0,0 & 0,0 & 0,0 \\
\hline 98. Conjuntos industriales & 0,0 & 0,0 & 0,0 & 0,0 & 0,0 \\
\hline 99. Conjuntos de otros productos & 1,4 & 1,8 & 1,6 & 0,1 & 0,1 \\
\hline TOTAL & 100,0 & 100,0 & 100,0 & 100,0 & 100,0 \\
\hline
\end{tabular}




\section{J .L. Placer Galán}

\section{Comercio exterior de León: Saldo comercial (en miles de euros)}

\begin{tabular}{|c|c|c|c|c|c|}
\hline Capítulos & 2010 & 2011 & 2012 & 2013 & 2014 \\
\hline 01. Animales vivos & $-4.408,40$ & $-3.908,30$ & $2.889,40$ & $1.488,30$ & $-1.915,60$ \\
\hline 02. Carne y despojos comestibles & $17.290,30$ & $21.555,10$ & $35.022,90$ & $36.201,40$ & $34.743,70$ \\
\hline 03. Pescados, crustáceos y moluscos & $-21.304,40$ & $-17.608,70$ & $-12.666,50$ & $-11.431,30$ & $-12.340,50$ \\
\hline 04. Leche, productos lácteos, huevos & $15.840,70$ & $13.305,50$ & $37.703,40$ & $55.775,40$ & $54.785,70$ \\
\hline 05. Otros productos de origen animal & $-132,7$ & $-348,4$ & $-189,2$ & $-200,3$ & $-266,7$ \\
\hline 06. Plantas vivas y productos de floricultura & $-353,2$ & $-387,3$ & $-330,2$ & $-279,2$ & $-271,5$ \\
\hline 07. Legumbres, hortalizas & $-66.842,90$ & $-59.005,40$ & $-79.456,60$ & $-76.307,50$ & $-62.100,40$ \\
\hline 08. Frutos comestibles & $-1.227,30$ & $-1.369,90$ & $-1.214,20$ & $1.500,30$ & $2.992,50$ \\
\hline 09. Café, té, yerba mate y especias & $-103,4$ & $-151,2$ & $-323,6$ & $-117,9$ & $-649,2$ \\
\hline 10. Cereales & $-21.463,00$ & $-24.011,30$ & $-27.572,70$ & $3.226,30$ & $-4.610,50$ \\
\hline 11. Productos de la molinería, malta & 0 & $-286,9$ & $-3.268,70$ & $-708,8$ & $-508,9$ \\
\hline 12. Semillas y frutos oleaginosos & $-2.586,60$ & $-3.525,50$ & $-4.677,70$ & $-4.016,80$ & $-4.409,50$ \\
\hline 13. Jugos y extractos vegetales & $-143,6$ & $-174,1$ & $-363,7$ & -279 & $-1.150,90$ \\
\hline 14. Materias trenzables & 0 & $-6,1$ & 0 & 0,8 & $-17,3$ \\
\hline 15. Grasas, aceite animal y vegetal & $-2.441,70$ & $-2.429,50$ & $-687,8$ & $-671,5$ & $-1.993,50$ \\
\hline 16. Conservas de carne o pescado & $2.121,60$ & $2.404,50$ & $2.628,10$ & $3.337,00$ & $3.335,90$ \\
\hline 17. Azúcares, artículos de confitería & 472,9 & $8.305,20$ & $17.984,10$ & $14.247,00$ & $8.125,90$ \\
\hline 18. Cacao y sus preparaciones & -6 & $-711,8$ & $-165,8$ & $-1.434,30$ & $-408,5$ \\
\hline 19. Productos de cereales, de pastelería & $1.496,40$ & 508,6 & $-1.376,10$ & $-1.425,80$ & $-3.088,90$ \\
\hline 20. Conservas de verdura o fruta, zumo & $-1.254,20$ & $-1.221,40$ & 405,4 & $-765,1$ & $-1.056,60$ \\
\hline 21. Preparaciones alimenticias diversas & $24.845,00$ & $24.571,50$ & $21.181,10$ & $18.512,90$ & $16.676,30$ \\
\hline 22. Bebidas de todo tipo (excluidos zumos) & $4.176,60$ & $5.078,00$ & $7.105,70$ & $7.897,40$ & $7.091,40$ \\
\hline 23. Residuos de la industria alimentaria & $2.518,80$ & $3.326,10$ & $3.964,60$ & $2.587,00$ & $9.162,80$ \\
\hline 24. Tabaco y sus sucedáneos & 0 & 0 & 0 & 0 & 0 \\
\hline 25. Sal, yeso piedras sin trabajar & $2.806,60$ & $2.709,30$ & 589,1 & 690,9 & $2.515,30$ \\
\hline 26. Minerales, escorias y cenizas & 108,1 & $2.719,20$ & $3.737,10$ & $2.173,70$ & $2.432,30$ \\
\hline 27. Combustibles, aceites minerales & $7.582,90$ & $-12.272,20$ & $4.540,20$ & 7,1 & $-1.478,70$ \\
\hline 28. Productos químicos inorgánicos & $-12.269,40$ & $-8.547,00$ & $-2.374,70$ & $-964,4$ & $-855,2$ \\
\hline 29. Productos químicos orgánicos & $17.762,80$ & $5.603,30$ & $2.045,70$ & $-8.765,40$ & $-14.774,10$ \\
\hline 30. Productos farmacéuticos & $16.314,20$ & $36.868,40$ & $52.117,80$ & $52.171,90$ & $65.800,50$ \\
\hline 31. Abonos & $-8.381,50$ & $-7.195,90$ & $-9.512,30$ & $-6.752,70$ & $-5.189,20$ \\
\hline 32. Tanino, materias colorantes, pintura & $4.282,30$ & 991,3 & $9.993,40$ & $6.982,00$ & $3.452,70$ \\
\hline 33. Aceites esenciales, preparac. de perfumería & $-203,2$ & $-811,5$ & $-348,4$ & $-381,3$ & $-1.165,50$ \\
\hline 34. Jabones, lubricantes, ceras & $-563,3$ & $-240,2$ & $-109,9$ & $-72,2$ & $-26,4$ \\
\hline 35. Materias albuminoideas, colas & $-1.181,40$ & $-890,3$ & $-1.225,60$ & $-988,9$ & $-966,9$ \\
\hline 36. Pólvoras y explosivos & $-711,4$ & $-14,3$ & $-25,2$ & $-4.054,80$ & $-9.437,30$ \\
\hline 37. Productos fotográficos o cinematográficos & $-9,4$ & $-0,2$ & 3,9 & 0 & $-1,3$ \\
\hline 38. Otros productos químicos & $-1.446,00$ & $-4.067,80$ & $-973,2$ & $-217,7$ & 145,3 \\
\hline 39. Materias plásticas y sus manufacturas & $-13.048,20$ & $-16.381,20$ & $-14.203,60$ & $-18.435,90$ & $-17.672,90$ \\
\hline 40. Caucho y sus manufacturas & $2.013,10$ & $-1.958,00$ & $2.116,80$ & $3.879,20$ & $7.985,90$ \\
\hline 41. Pieles (excepto la peletería) y cueros & $1.469,90$ & $2.792,70$ & $2.105,50$ & $3.038,50$ & $1.390,60$ \\
\hline 42. Manufacturas de cuero, marroquinería & $-1.439,60$ & $-3.217,70$ & $-757,5$ & $-3.333,00$ & $-2.034,60$ \\
\hline 43. Peletería y sus confecciones & $1.077,10$ & 596,3 & 780,6 & 316,2 & 431,6 \\
\hline 44. Madera y sus manufacturas & $10.607,30$ & $10.996,70$ & $13.321,40$ & $18.358,40$ & $14.765,20$ \\
\hline 45. Corcho y sus manufacturas & $-102,1$ & $-104,6$ & $-362,9$ & $-165,1$ & $-202,7$ \\
\hline 46. Manufacturas de cestería & 8,7 & $-33,4$ & $-0,7$ & $-5,5$ & $-7,7$ \\
\hline 47. Pasta de madera, papel reciclado & $-17,4$ & $-1,3$ & $-4,4$ & $-17,8$ & $-36,9$ \\
\hline 48. Papel y cartón, sus manufacturas & $-3.313,40$ & $-1.830,50$ & $-4.107,20$ & $-2.890,20$ & $-4.843,40$ \\
\hline 49. Libros, publicaciones, artes gráficas & $2.566,60$ & $2.474,70$ & $1.966,80$ & $1.907,90$ & $1.806,80$ \\
\hline
\end{tabular}




\section{Comercio exterior de León: Saldo comercial (cont.)}

\begin{tabular}{|c|c|c|c|c|c|}
\hline Capítulos & 2010 & 2011 & 2012 & 2013 & 2014 \\
\hline 50. Seda & 0 & 0 & $-2,6$ & $-8,1$ & $-8,6$ \\
\hline 51. Lana y pelo fino & 0,2 & 0 & 0 & 0 & $-5,5$ \\
\hline 52. Algodón & $-64,2$ & $-32,9$ & $-50,5$ & $-274,6$ & 56,5 \\
\hline 53. Otras fibras textiles vegetales & $-5,5$ & 0 & 0,5 & $-0,1$ & $-0,2$ \\
\hline 54. Filamentos sintéticos o artificiales & $-28,4$ & $-5,6$ & $-30,5$ & -55 & $-51,6$ \\
\hline 55. Fibras sintéticas o artificiales discontinuas & -170 & $-220,6$ & $-164,4$ & $-210,1$ & $-138,7$ \\
\hline 56. Fieltro, tela sin tejer, cordelería & $-158,4$ & $-123,1$ & $-175,9$ & $-51,3$ & -41 \\
\hline 57. Alfombras y revestimientos textiles para el suelo & $-249,7$ & $-61,2$ & $-49,1$ & $-62,2$ & $-40,1$ \\
\hline 58. Tejidos especiales, tapicería, bordados & $-9,1$ & -18 & 10,4 & $-15,8$ & $-4,9$ \\
\hline 59. Tejidos recubiertos, técnicos de materias textiles & $-113,3$ & -82 & $-215,4$ & $-87,9$ & $-44,6$ \\
\hline 60. Tejidos de punto & -7 & $-28,7$ & -56 & $-0,1$ & $-3,6$ \\
\hline 61. Prendas de vestir de punto & $-3.473,50$ & $-3.061,70$ & $-3.255,70$ & $-374,6$ & $-2.712,40$ \\
\hline 62. Prendas de vestir, excepto las de punto & $-4.295,70$ & $-5.239,50$ & $-3.976,00$ & $-896,6$ & $-2.359,60$ \\
\hline 63. Demás artículos textiles, prendería & -582 & $-176,3$ & $-146,6$ & $-134,3$ & $-85,3$ \\
\hline 64. Calzado y sus partes & $-2.222,40$ & $-1.756,50$ & $-1.304,90$ & $-970,2$ & $-1.207,10$ \\
\hline 65. Artículos de sombrerería & $-92,1$ & $-122,9$ & 57,6 & 113,5 & 30,7 \\
\hline 66. Paraguas, sombrillas, bastones & $-10,4$ & $-23,5$ & $-5,1$ & $-4,4$ & $-19,4$ \\
\hline 67. Plumas y plumón preparados & $-25,9$ & $-47,5$ & $-48,4$ & $-33,3$ & $-29,3$ \\
\hline 68. Manufacturas de piedra, yeso & $73.608,30$ & $75.728,90$ & $68.906,20$ & $61.414,40$ & $64.220,30$ \\
\hline 69. Productos cerámicos & $-2.439,70$ & $-2.126,50$ & $-1.410,40$ & $-1.736,50$ & $-2.083,60$ \\
\hline 70. Vidrio y sus manufacturas & $14.284,20$ & $15.258,20$ & $25.875,90$ & $25.182,90$ & $29.875,10$ \\
\hline 71. Piedras y metales preciosos, bisutería & $-480,2$ & -497 & -395 & $-302,5$ & $-318,2$ \\
\hline 72. Fundición, hierro y acero & $221.523,50$ & $147.595,50$ & $193.732,70$ & $150.660,50$ & $172.871,80$ \\
\hline 73. Manufacturas de fundición, hierro y acero & $14.672,30$ & $5.397,20$ & $9.874,70$ & $6.208,80$ & $40.747,30$ \\
\hline 74. Cobre y sus manufacturas & $7.553,20$ & $5.725,00$ & $5.840,40$ & $-2.478,70$ & $-8.426,60$ \\
\hline 75. Níquel y sus manufacturas & -1 & $-0,9$ & -1 & $-14,5$ & $-0,8$ \\
\hline 76. Aluminio y sus manufacturas & $-1.221,30$ & 704,7 & $2.583,20$ & $-1.669,60$ & $-3.137,70$ \\
\hline 78. Plomo y sus manufacturas & $-37,8$ & 73,1 & 0 & 0 & 0 \\
\hline 79. Cinc y sus manufacturas & 66,5 & 266 & 94,5 & $-27,4$ & -66 \\
\hline 80. Estaño y sus manufacturas & $-1,5$ & $-9,3$ & $-1,4$ & $-0,5$ & $-486,4$ \\
\hline 81. Demás metales comunes, cermets & $-117,3$ & $-181,9$ & $-50,9$ & $-11,9$ & 9,5 \\
\hline 82. Herramientas y cuchillos metálicos & $-903,8$ & $-1.035,20$ & $-352,9$ & $-208,9$ & $-897,9$ \\
\hline 83. Manufacturas diversas de metales & 362,3 & 395 & 878,6 & 524,6 & 764,3 \\
\hline 84. Máquinas y aparatos mecánicos & \begin{tabular}{|l|}
$-71.307,10$ \\
\end{tabular} & $10.045,00$ & $5.542,70$ & $-5.073,30$ & $23.541,40$ \\
\hline 85. Máquinas, aparatos y material eléctricos & $235.481,00$ & $653.176,50$ & $785.703,50$ & $512.051,00$ & $462.566,10$ \\
\hline 86. Vehículos, material ferroviarios & $-446,5$ & $-610,6$ & $-448,7$ & $-242,6$ & $-37,7$ \\
\hline 87. Vehículos automóviles, tractores & $-2.742,10$ & $-4.016,60$ & $4.914,20$ & $-5.019,40$ & $-10.599,40$ \\
\hline 88. Aeronaves, vehículos espaciales & 1,4 & $-19,1$ & $-57,6$ & 0 & $-2,1$ \\
\hline 89. Barcos y embarcaciones & 0 & 0 & 0 & $-0,9$ & $-6,6$ \\
\hline 90. Aparatos ópticos, de medida, médicos & $-3.490,80$ & $-3.275,70$ & $-3.554,50$ & $-4.155,70$ & $-5.012,70$ \\
\hline 91. Relojería & -54 & 44,4 & $-403,8$ & $-400,8$ & $-76,5$ \\
\hline 92. Instrumentos musicales & $-8,8$ & -9 & $-7,2$ & $-1.231,40$ & $-3,9$ \\
\hline 93. Armas y municiones, accesorios & $-4.129,80$ & $-5.211,70$ & $-5.153,60$ & $-2.565,80$ & $-3.420,00$ \\
\hline 94. Muebles, sillas, lámparas & 686,6 & 766,3 & $-99,4$ & $-32,8$ & $2.032,70$ \\
\hline 95. Juguetes, juegos, artículos deportivos & $-230,8$ & $-298,5$ & $-16,6$ & -157 & $-184,1$ \\
\hline 96. Manufacturas diversas & $-175,3$ & $-322,1$ & $-263,2$ & $-269,2$ & $-317,7$ \\
\hline 97. Objetos de arte, antigüedades & $-24,9$ & -6 & $-6,6$ & $-2,6$ & -5 \\
\hline 98. Conjuntos industriales & 0 & 0 & 0 & 0 & 0 \\
\hline 99. Conjuntos de otros productos & $-5.674,00$ & $-1.867,70$ & $-2.316,40$ & $-88,5$ & $-388,1$ \\
\hline TOTAL & $433.653,60$ & $856.782,70$ & $1.135 .899,80$ & $816.903,80$ & $838.651,50$ \\
\hline
\end{tabular}




\section{J.L. Placer Galán}

\section{Comercio exterior de León: Tasa de cobertura}

\begin{tabular}{|c|c|c|c|c|c|}
\hline Capítulos & 2010 & 2011 & 2012 & 2013 & 2014 \\
\hline 01. Animales vivos & 34,9 & 1,8 & 160,7 & 147,2 & 50,5 \\
\hline 02. Carne y despojos comestibles & 672,6 & 655,6 & $1.150,00$ & $1.795,20$ & $1.690,60$ \\
\hline 03. Pescados, crustáceos y moluscos & 7,3 & 7,6 & 9,5 & 5,6 & 5,2 \\
\hline 04. Leche, productos lácteos, huevos & 291,4 & 194,6 & 423,9 & 597,5 & 483,9 \\
\hline 05. Otros productos de origen animal & 56,2 & 42 & 66 & 57,7 & 44,5 \\
\hline 06. Plantas vivas y productos de floricultura & 0 & 0 & 0 & 0 & 0 \\
\hline 07. Legumbres, hortalizas & 11,3 & 12,1 & 10 & 11,3 & 9,6 \\
\hline 08. Frutos comestibles & 26,5 & 20,1 & 42,1 & 151,7 & 193,5 \\
\hline 09. Café, té, yerba mate y especias & 82,7 & 78,3 & 66,8 & 85,5 & 45,2 \\
\hline 10. Cereales & 14,1 & 18,4 & 18,4 & 179,4 & 62,7 \\
\hline 11. Productos de la molinería, malta & - & 0,1 & 0 & 2,3 & 0 \\
\hline 12. Semillas y frutos oleaginosos & 68,5 & 58,3 & 53 & 61,1 & 65,7 \\
\hline 13. Jugos y extractos vegetales & 14,2 & 6,7 & 0,7 & 0,8 & 0,2 \\
\hline 14. Materias trenzables & - & 0 & - & 449,3 & 0 \\
\hline 15. Grasas, aceite animal y vegetal & 0,1 & 5,4 & 0,5 & 30,5 & 9,6 \\
\hline 16. Conservas de carne o pescado & 479,3 & 652,7 & 747,7 & $2.782,30$ & 616,2 \\
\hline 17. Azúcares, artículos de confitería & 243,6 & 950,5 & 871,2 & 253,2 & 156,8 \\
\hline 18. Cacao y sus preparaciones & 20,1 & 0,2 & 7,2 & 0 & 0 \\
\hline 19. Productos de cereales, de pastelería & 333 & 195,9 & 14,5 & 9,4 & 8,7 \\
\hline 20. Conservas de verdura o fruta, zumo & 54,9 & 65,9 & 113,7 & 83,5 & 78,6 \\
\hline 21. Preparaciones alimenticias diversas & $5.722,70$ & $7.683,40$ & $3.071,00$ & $5.182,60$ & $2.028,50$ \\
\hline 22. Bebidas de todo tipo (excluidos zumos) & $8.893,00$ & $2.438,00$ & $2.088,10$ & $2.561,40$ & 405,5 \\
\hline 23. Residuos de la industria alimentaria & 138,4 & 152,3 & 174,1 & 151,4 & 247,8 \\
\hline 24. Tabaco y sus sucedáneos & - & - & - & - & - \\
\hline 25. Sal, yeso piedras sin trabajar & 441,3 & 335,3 & 197,3 & 424,2 & 894,3 \\
\hline 26. Minerales, escorias y cenizas & 321,5 & $1.017,80$ & $3.082,20$ & $3.707,90$ & $1.674,00$ \\
\hline 27. Combustibles, aceites minerales & 545,5 & 40,4 & 378,9 & 100,2 & 78 \\
\hline 28. Productos químicos inorgánicos & 0 & 5,4 & 0,2 & 1 & 0,1 \\
\hline 29. Productos químicos orgánicos & 206,9 & 127,3 & 109,4 & 24,8 & 0,1 \\
\hline 30. Productos farmacéuticos & 870,8 & $2.652,90$ & $2.477,50$ & $3.157,50$ & $3.245,50$ \\
\hline 31. Abonos & 3 & 0 & 0 & 1,5 & 1,5 \\
\hline 32. Tanino, materias colorantes, pintura & 204,8 & 114,2 & 263 & 195,8 & 159,6 \\
\hline 33. Aceites esenciales, preparac. de perfumería & 61,1 & 17,4 & 37,1 & 35,6 & 18,9 \\
\hline 34. Jabones, lubricantes, ceras & 2,5 & 33,7 & 24,5 & 43,7 & 94,8 \\
\hline 35. Materias albuminoideas, colas & 0,5 & 0,7 & 0,3 & 2,6 & 6,7 \\
\hline 36. Pólvoras y explosivos & 0 & 0 & 0 & 10,6 & 3,2 \\
\hline 37. Productos fotográficos o cinematográficos & 0 & 0 & $1.015,50$ & 0 & 0 \\
\hline 38. Otros productos químicos & 15,9 & 10,7 & 50,7 & 89,4 & 107 \\
\hline 39. Materias plásticas y sus manufacturas & 4 & 4,7 & 14,7 & 7 & 12,2 \\
\hline 40. Caucho y sus manufacturas & 155,7 & 47,3 & 177,8 & 266,5 & 410,9 \\
\hline 41. Pieles (excepto la peletería) y cueros & 236,7 & 337,7 & 268,7 & 306,5 & 295,9 \\
\hline 42. Manufacturas de cuero, marroquinería & 3,3 & 1,3 & 3 & 5,6 & 3,5 \\
\hline 43. Peletería y sus confecciones & 605,1 & 285,1 & 449 & 365,2 & 553,9 \\
\hline 44. Madera y sus manufacturas & 358,6 & 385,5 & 523,6 & 650,2 & 384,3 \\
\hline 45. Corcho y sus manufacturas & 4,6 & 0 & 0,1 & 0 & 15,1 \\
\hline 46. Manufacturas de cestería & 992 & 0,8 & 0 & 0 & 0 \\
\hline 47. Pasta de madera, papel reciclado & 46,1 & 5,3 & 8,7 & 0,5 & 1 \\
\hline 48. Papel y cartón, sus manufacturas & 6,5 & 57,6 & 14,7 & 9,1 & 12 \\
\hline 49. Libros, publicaciones, artes gráficas & 412,1 & 633,2 & 381,8 & 521,1 & 967,4 \\
\hline
\end{tabular}




\section{Comercio exterior de León: Tasa de cobertura (cont.)}

\begin{tabular}{|c|c|c|c|c|c|}
\hline Capítulos & 2010 & 2011 & 2012 & 2013 & 2014 \\
\hline 50. Seda & - & - & 0 & 0 & 0 \\
\hline 51. Lana y pelo fino & 121 & - & - & - & 0 \\
\hline 52. Algodón & 3,6 & 40,2 & 6,9 & 3,5 & 115,8 \\
\hline 53. Otras fibras textiles vegetales & 0 & - & - & 0 & 0 \\
\hline 54. Filamentos sintéticos o artificiales & 0 & 87,3 & 40,6 & 3,7 & 65,2 \\
\hline 55. Fibras sintéticas o artificiales discontinuas & 0 & 13 & 26,4 & 19,8 & 1,4 \\
\hline 56. Fieltro, tela sin tejer, cordelería & 2,6 & 6,2 & 3,5 & 23,1 & 16,6 \\
\hline 57. Alfombras y revestimientos textiles para el suelo & 0 & 3 & 0 & 0,4 & 0 \\
\hline 58. Tejidos especiales, tapicería, bordados & 5,3 & 0 & 148 & 0,1 & 12,9 \\
\hline 59. Tejidos recubiertos, técnicos de materias textiles & 7 & 0,4 & 6,3 & 0 & 0,1 \\
\hline 60. Tejidos de punto & 0 & 0 & 0 & 0 & 21,6 \\
\hline 61. Prendas de vestir de punto & 3,3 & 14,7 & 4,3 & 87,5 & 12,4 \\
\hline 62. Prendas de vestir, excepto las de punto & 25,5 & 24,9 & 31,7 & 85 & 65,6 \\
\hline 63. Demás artículos textiles, prendería & 3,5 & 6,9 & 12 & 34 & 58,2 \\
\hline 64. Calzado y sus partes & 1,5 & 3,1 & 4,6 & 6,9 & 7,8 \\
\hline 65. Artículos de sombrerería & 6,6 & 5,6 & 156,9 & 217 & 125 \\
\hline 66. Paraguas, sombrillas, bastones & 20,9 & 3,7 & 30,9 & 61,6 & 5,2 \\
\hline 67. Plumas y plumón preparados & 0 & 0 & 0 & 0 & 0 \\
\hline 68. Manufacturas de piedra, yeso & $3.329,40$ & $3.038,40$ & $1.660,10$ & $1.787,90$ & $1.709,40$ \\
\hline 69. Productos cerámicos & 15,1 & 13,6 & 10,9 & 7,8 & 10,3 \\
\hline 70. Vidrio y sus manufacturas & 302,9 & 214,3 & 332,2 & 321,1 & 290,9 \\
\hline 71. Piedras y metales preciosos, bisutería & 0,3 & 2,6 & 0,5 & 26,2 & 30,2 \\
\hline 72. Fundición, hierro y acero & $11.930,70$ & 886 & $8.810,50$ & $6.164,30$ & $9.532,30$ \\
\hline 73. Manufacturas de fundición, hierro y acero & 544,8 & 208,8 & 288,1 & 161,5 & 739 \\
\hline 74. Cobre y sus manufacturas & 146,9 & 129,5 & 118,7 & 87,1 & 52,8 \\
\hline 75. Níquel y sus manufacturas & 0 & 0 & 0 & 0 & 0 \\
\hline 76. Aluminio y sus manufacturas & 65,6 & 116,8 & 151,6 & 66 & 42,2 \\
\hline 78. Plomo y sus manufacturas & 0 & - & - & - & \\
\hline 79. Cinc y sus manufacturas & 130,4 & $1.173,20$ & 148,1 & 89,2 & 81,7 \\
\hline 80. Estaño y sus manufacturas & 0 & 0 & 0 & 0 & 6,6 \\
\hline 81. Demás metales comunes, cermets & 0 & 0 & 46,1 & 0 & 132,7 \\
\hline 82. Herramientas y cuchillos metálicos & 13,2 & 8,6 & 55,3 & 57,8 & 6 \\
\hline 83. Manufacturas diversas de metales & 271,2 & 394,1 & 555,9 & 298 & 322,3 \\
\hline 84. Máquinas y aparatos mecánicos & 7,6 & 140,3 & 125,6 & 78 & 177,6 \\
\hline 85. Máquinas, aparatos y material eléctricos & 757 & $7.136,00$ & $13.862,20$ & $2.350,80$ & $3.339,20$ \\
\hline 86. Vehículos, material ferroviarios & 4,9 & 7,3 & 0,7 & 0,2 & 85,1 \\
\hline 87. Vehículos automóviles, tractores & 77,3 & 63,9 & 163,1 & 48,5 & 27,2 \\
\hline 88. Aeronaves, vehículos espaciales & - & 0 & 2,8 & - & 0 \\
\hline 89. Barcos y embarcaciones & - & - & - & 0 & 0 \\
\hline 90. Aparatos ópticos, de medida, médicos & 12,3 & 16,4 & 25,8 & 12,7 & 14,9 \\
\hline 91. Relojería & 82,9 & 112,1 & 2,8 & 32 & 81 \\
\hline 92. Instrumentos musicales & 0 & 9,5 & 0 & 0 & 27,8 \\
\hline 93. Armas y municiones, accesorios & 42,7 & 3,1 & 1,4 & 60 & 47,2 \\
\hline 94. Muebles, sillas, lámparas & 125,7 & 146 & 92,6 & 97 & 244,4 \\
\hline 95. Juguetes, juegos, artículos deportivos & 4 & 4,5 & 89,8 & 26 & 11,3 \\
\hline 96. Manufacturas diversas & 35,1 & 13,9 & 16 & 2,7 & 5,8 \\
\hline 97. Objetos de arte, antigüedades & 0 & 0 & 19 & 0 & 0,8 \\
\hline 98. Conjuntos industriales & - & - & - & - & \\
\hline 99. Conjuntos de otros productos & 9 & 75,2 & 63,1 & 74 & 34,8 \\
\hline TOTAL & 197,5 & 303,6 & 387,3 & 319,9 & 309,5 \\
\hline
\end{tabular}




\section{J.L. PlacerGalán}

\section{Comercio exterior de León: Cuota de exportaciones sobre Castilla y León (en porcentaje)}

\begin{tabular}{|c|c|c|c|c|c|}
\hline Capítulos & 2010 & 2011 & 2012 & 2013 & 2014 \\
\hline 01. Animales vivos & 9,7 & 0,2 & 16,9 & 9,6 & 4,8 \\
\hline 02. Carne y despojos comestibles & 9,1 & 9,2 & 11,9 & 12,6 & 12,4 \\
\hline 03. Pescados, crustáceos y moluscos & 6,1 & 5,1 & 5,7 & 2,5 & 2,2 \\
\hline 04. Leche, productos lácteos, huevos & 17,2 & 20,3 & 30,5 & 34,2 & 33,1 \\
\hline 05. Otros productos de origen animal & 3,8 & 4,5 & 6,1 & 4,0 & 3,3 \\
\hline 06. Plantas vivas y productos de floricultura & 0,0 & 0,0 & 0,0 & 0,0 & 0,0 \\
\hline 07. Legumbres, hortalizas & 20,1 & 21,4 & 20,6 & 18,2 & 14,8 \\
\hline 08. Frutos comestibles & 2,4 & 1,3 & 3,2 & 19,3 & 21,3 \\
\hline 09. Café, té, yerba mate y especias & 9,8 & 17,4 & 46,0 & 54,0 & 46,9 \\
\hline 10. Cereales & 11,8 & 15,9 & 18,1 & 16,7 & 15,8 \\
\hline 11. Productos de la molinería, malta & 0,0 & 0,0 & 0,0 & 0,2 & 0,0 \\
\hline 12. Semillas y frutos oleaginosos & 43,1 & 30,6 & 28,3 & 36,2 & 37,9 \\
\hline 13. Jugos y extractos vegetales & 0,4 & 0,2 & 0,0 & 0,0 & 0,0 \\
\hline 14. Materias trenzables & 0,0 & 0,0 & 0,0 & 3,5 & 0,0 \\
\hline 15. Grasas, aceite animal y vegetal & 0,0 & 0,8 & 0,0 & 0,9 & 0,7 \\
\hline 16. Conservas de carne o pescado & 7,5 & 7,0 & 6,7 & 7,3 & 9,1 \\
\hline 17. Azúcares, artículos de confitería & 1,1 & 12,2 & 24,6 & 38,0 & 34,5 \\
\hline 18. Cacao y sus preparaciones & 0,1 & 0,1 & 0,7 & 0,0 & 0,0 \\
\hline 19. Productos de cereales, de pastelería & 2,3 & 1,0 & 0,2 & 0,1 & 0,2 \\
\hline 20. Conservas de verdura o fruta, zumo & 4,5 & 8,5 & 10,5 & 10,2 & 7,4 \\
\hline 21. Preparaciones alimenticias diversas & 17,5 & 21,0 & 17,6 & 16,4 & 13,7 \\
\hline 22. Bebidas de todo tipo (excluidos zumos) & 2,9 & 2,9 & 4,1 & 4,3 & 4,5 \\
\hline 23. Residuos de la industria alimentaria & 9,0 & 8,7 & 8,9 & 7,7 & 16,1 \\
\hline 24. Tabaco y sus sucedáneos & 0,0 & 0,0 & 0,0 & 0,0 & 0,0 \\
\hline 25. Sal, yeso piedras sin trabajar & 19,9 & 18,3 & 6,9 & 6,2 & 18,3 \\
\hline 26. Minerales, escorias y cenizas & 3,4 & 17,0 & 21,0 & 15,4 & 11,7 \\
\hline 27. Combustibles, aceites minerales & 33,7 & 29,3 & 22,5 & 59,2 & 63,3 \\
\hline 28. Productos químicos inorgánicos & 0,0 & 0,8 & 0,0 & 0,0 & 0,0 \\
\hline 29. Productos químicos orgánicos & 44,9 & 37,2 & 25,6 & 4,0 & 0,0 \\
\hline 30. Productos farmacéuticos & 2,2 & 3,7 & 4,4 & 5,5 & 7,0 \\
\hline 31. Abonos & 6,8 & 0,0 & 0,0 & 3,3 & 1,8 \\
\hline 32. Tanino, materias colorantes, pintura & 20,2 & 26,0 & 33,1 & 30,8 & 18,6 \\
\hline 33. Aceites esenciales, preparac. de perfumería & 0,2 & 0,1 & 0,1 & 0,1 & 0,1 \\
\hline 34. Jabones, lubricantes, ceras & 0,1 & 0,9 & 0,3 & 0,7 & 6,2 \\
\hline 35. Materias albuminoideas, colas & 0,3 & 0,2 & 0,1 & 0,7 & 1,5 \\
\hline 36. Pólvoras y explosivos & 0,0 & 0,0 & 0,0 & 6,5 & 3,6 \\
\hline 37. Productos fotográficos o cinematográficos & 0,0 & 0,0 & 65,7 & 0,0 & 0,0 \\
\hline 38. Otros productos químicos & 0,5 & 1,1 & 3,2 & 4,1 & 6,1 \\
\hline 39. Materias plásticas y sus manufacturas & 0,6 & 0,9 & 2,4 & 1,2 & 1,9 \\
\hline 40. Caucho y sus manufacturas & 1,1 & 0,3 & 0,9 & 1,1 & 1,8 \\
\hline 41. Pieles (excepto la peletería) y cueros & 6,3 & 7,8 & 7,9 & 8,9 & 8,1 \\
\hline 42. Manufacturas de cuero, marroquinería & 1,6 & 1,0 & 0,6 & 4,7 & 2,0 \\
\hline 43. Peletería y sus confecciones & 60,0 & 26,9 & 26,4 & 8,8 & 14,4 \\
\hline 44. Madera y sus manufacturas & 15,8 & 16,8 & 22,6 & 25,1 & 20,8 \\
\hline 45. Corcho y sus manufacturas & 0,4 & 0,0 & 0,0 & 0,0 & 2,4 \\
\hline 46. Manufacturas de cestería & 2,1 & 0,1 & 0,0 & 0,0 & 0,0 \\
\hline 47. Pasta de madera, papel reciclado & 4,3 & 0,0 & 0,1 & 0,0 & 0,2 \\
\hline 48. Papel y cartón, sus manufacturas & 0,1 & 1,1 & 0,5 & 0,2 & 0,5 \\
\hline 49. Libros, publicaciones, artes gráficas & 56,0 & 34,2 & 27,5 & 22,1 & 19,0 \\
\hline
\end{tabular}


Comercio exterior de León: Cuota de exportaciones sobre Castilla y León (cont.)

\begin{tabular}{|c|c|c|c|c|c|}
\hline Capítulos & 2010 & 2011 & 2012 & 2013 & 2014 \\
\hline 50. Seda & 0,0 & 0,0 & 0,0 & 0,0 & 0,0 \\
\hline 51. Lana y pelo fino & 0,0 & 0,0 & 0,0 & 0,0 & 0,0 \\
\hline 52. Algodón & 0,1 & 1,2 & 0,3 & 0,8 & 24,7 \\
\hline 53. Otras fibras textiles vegetales & 0,0 & 0,0 & 25,2 & 0,0 & 0,0 \\
\hline 54. Filamentos sintéticos o artificiales & 0,0 & 2,3 & 1,4 & 0,3 & 10,5 \\
\hline 55. Fibras sintéticas o artificiales discontinuas & 0,0 & 8,7 & 16,0 & 8,1 & 0,4 \\
\hline 56. Fieltro, tela sin tejer, cordelería & 0,3 & 0,4 & 0,6 & 2,6 & 0,7 \\
\hline 57. Alfombras y revestimientos textiles para el suelo & 0,0 & 0,2 & 0,0 & 0,0 & 0,0 \\
\hline 58. Tejidos especiales, tapicería, bordados & 0,0 & 0,0 & 1,6 & 0,0 & 0,0 \\
\hline 59. Tejidos recubiertos, técnicos de materias textiles & 0,0 & 0,0 & 0,1 & 0,0 & 0,0 \\
\hline 60. Tejidos de punto & 0,0 & 0,0 & 0,0 & 0,0 & 0,8 \\
\hline 61. Prendas de vestir de punto & 2,7 & 10,4 & 3,9 & 43,3 & 8,5 \\
\hline 62. Prendas de vestir, excepto las de punto & 17,0 & 16,9 & 21,6 & 43,8 & 41,1 \\
\hline 63. Demás artículos textiles, prendería & 2,4 & 0,8 & 1,0 & 4,1 & 6,5 \\
\hline 64. Calzado y sus partes & 2,3 & 2,8 & 1,9 & 2,8 & 9,0 \\
\hline 65. Artículos de sombrerería & 11,9 & 5,9 & 54,1 & 59,7 & 65,7 \\
\hline 66. Paraguas, sombrillas, bastones & 10,7 & 5,8 & 2,5 & 31,8 & 5,6 \\
\hline 67. Plumas y plumón preparados & 0,0 & 0,0 & 0,0 & 0,0 & 0,0 \\
\hline 68. Manufacturas de piedra, yeso & 83,0 & 82,4 & 89,5 & 86,3 & 90,3 \\
\hline 69. Productos cerámicos & 4,7 & 3,0 & 1,4 & 1,0 & 1,5 \\
\hline 70. Vidrio y sus manufacturas & 24,9 & 33,4 & 36,6 & 37,6 & 41,7 \\
\hline 71. Piedras y metales preciosos, bisutería & 0,1 & 1,1 & 0,1 & 3,6 & 6,7 \\
\hline 72. Fundición, hierro y acero & 74,7 & 66,2 & 75,1 & 68,1 & 57,6 \\
\hline 73. Manufacturas de fundición, hierro y acero & 15,3 & 7,2 & 9,6 & 9,7 & 22,9 \\
\hline 74. Cobre y sus manufacturas & 93,0 & 84,5 & 95,5 & 82,8 & 75,2 \\
\hline 75. Níquel y sus manufacturas & 0,0 & 0,0 & 0,0 & 0,0 & 0,0 \\
\hline 76. Aluminio y sus manufacturas & 3,0 & 4,7 & 7,7 & 3,2 & 2,2 \\
\hline 78. Plomo y sus manufacturas & 0,0 & 70,8 & 0,0 & 0,0 & 0,0 \\
\hline 79. Cinc y sus manufacturas & 25,5 & 65,2 & 28,7 & 22,4 & 72,2 \\
\hline 80. Estaño y sus manufacturas & 0,0 & 0,0 & - & - & 100,0 \\
\hline 81. Demás metales comunes, cermets & 0,0 & 0,0 & 15,2 & 0,0 & 12,2 \\
\hline 82. Herramientas y cuchillos metálicos & 2,5 & 4,1 & 15,0 & 8,5 & 2,6 \\
\hline 83. Manufacturas diversas de metales & 0,8 & 0,8 & 1,7 & 1,5 & 1,8 \\
\hline 84. Máquinas y aparatos mecánicos & 0,4 & 1,8 & 1,7 & 1,0 & 2,9 \\
\hline 85. Máquinas, aparatos y material eléctricos & 71,0 & 84,1 & 89,9 & 66,3 & 61,5 \\
\hline 86. Vehículos, material ferroviarios & 0,5 & 0,9 & 0,0 & 0,0 & 3,0 \\
\hline 87. Vehículos automóviles, tractores & 0,2 & 0,2 & 0,3 & 0,1 & 0,1 \\
\hline 88. Aeronaves, vehículos espaciales & 0,0 & 0,0 & 0,0 & 0,0 & 0,0 \\
\hline 89. Barcos y embarcaciones & 0,0 & 0,0 & 0,0 & 0,0 & 0,0 \\
\hline 90. Aparatos ópticos, de medida, médicos & 13,5 & 10,8 & 18,5 & 6,0 & 7,6 \\
\hline 91. Relojería & 24,6 & 35,4 & 1,7 & 8,8 & 14,4 \\
\hline 92. Instrumentos musicales & 0,0 & 1,8 & 0,0 & 17,4 & 82,9 \\
\hline 93. Armas y municiones, accesorios & 9,5 & 19,9 & 5,4 & 93,9 & 67,5 \\
\hline 94. Muebles, sillas, lámparas & 6,4 & 3,8 & 2,1 & 1,4 & 4,5 \\
\hline 95. Juguetes, juegos, artículos deportivos & 1,1 & 1,2 & 15,5 & 6,4 & 2,4 \\
\hline 96. Manufacturas diversas & 3,4 & 2,4 & 0,1 & 0,0 & 0,0 \\
\hline 97. Objetos de arte, antigüedades & 0,0 & 0,0 & 0,3 & 0,0 & 0,0 \\
\hline 98. Conjuntos industriales & -1 & - & - & - & \\
\hline 99. Conjuntos de otros productos & 0,2 & 2,0 & 1,1 & 0,1 & 0,1 \\
\hline TOTAL & 8,4 & 10,6 & 13,1 & 9,7 & 9,7 \\
\hline
\end{tabular}




\section{J.L. PlacerGalán}

\section{Comercio exterior de León: Cuota de importaciones sobre Castilla y León (en porcentaje)}

\begin{tabular}{|c|c|c|c|c|c|}
\hline Capítulos & 2010 & 2011 & 2012 & 2013 & 2014 \\
\hline 01. Animales vivos & 24,8 & 13,0 & 15,8 & 10,0 & 10,5 \\
\hline 02. Carne y despojos comestibles & 6,6 & 8,2 & 8,0 & 4,1 & 4,1 \\
\hline 03. Pescados, crustáceos y moluscos & 13,2 & 10,9 & 15,0 & 12,6 & 10,9 \\
\hline 04. Leche, productos lácteos, huevos & 8,6 & 15,8 & 13,8 & 12,2 & 15,1 \\
\hline 05. Otros productos de origen animal & 6,9 & 10,5 & 8,2 & 4,6 & 7,3 \\
\hline 06. Plantas vivas y productos de floricultura & 6,5 & 6,3 & 6,1 & 4,4 & 4,9 \\
\hline 07. Legumbres, hortalizas & 66,1 & 65,7 & 74,4 & 68,1 & 63,1 \\
\hline 08. Frutos comestibles & 4,7 & 4,3 & 8,4 & 12,8 & 13,6 \\
\hline 09. Café, té, yerba mate y especias & 1,7 & 2,8 & 2,5 & 2,8 & 4,1 \\
\hline 10. Cereales & 36,7 & 49,4 & 43,8 & 10,1 & 14,3 \\
\hline 11. Productos de la molinería, malta & 0,0 & 2,4 & 21,9 & 6,7 & 4,3 \\
\hline 12. Semillas y frutos oleaginosos & 20,2 & 25,2 & 27,4 & 25,7 & 26,2 \\
\hline 13. Jugos y extractos vegetales & 3,0 & 3,6 & 6,9 & 4,4 & 14,6 \\
\hline 14. Materias trenzables & 0,0 & 4,5 & 0,0 & 0,3 & 31,2 \\
\hline 15. Grasas, aceite animal y vegetal & 7,2 & 5,0 & 1,4 & 2,6 & 7,9 \\
\hline 16. Conservas de carne o pescado & 2,1 & 1,8 & 1,3 & 0,5 & 2,1 \\
\hline 17. Azúcares, artículos de confitería & 0,3 & 0,9 & 2,8 & 8,5 & 15,9 \\
\hline 18. Cacao y sus preparaciones & 0,1 & 9,1 & 1,2 & 10,2 & 2,7 \\
\hline 19. Productos de cereales, de pastelería & 1,9 & 1,3 & 3,3 & 3,3 & 9,6 \\
\hline 20. Conservas de verdura o fruta, zumo & 6,7 & 7,7 & 7,9 & 13,0 & 8,2 \\
\hline 21. Preparaciones alimenticias diversas & 1,3 & 1,2 & 2,5 & 1,6 & 3,4 \\
\hline 22. Bebidas de todo tipo (excluidos zumos) & 0,2 & 0,8 & 0,8 & 1,2 & 10,5 \\
\hline 23. Residuos de la industria alimentaria & 14,9 & 14,8 & 8,9 & 9,4 & 11,9 \\
\hline 24. Tabaco y sus sucedáneos & 0,0 & - & - & 0,0 & 0,0 \\
\hline 25. Sal, yeso piedras sin trabajar & 8,7 & 6,1 & 4,8 & 2,3 & 2,8 \\
\hline 26. Minerales, escorias y cenizas & 2,0 & 17,6 & 13,4 & 75,4 & 17,9 \\
\hline 27. Combustibles, aceites minerales & 7,9 & 33,0 & 2,8 & 21,3 & 31,0 \\
\hline 28. Productos químicos inorgánicos & 2,5 & 2,0 & 0,5 & 0,3 & 0,3 \\
\hline 29. Productos químicos orgánicos & 4,9 & 6,5 & 4,8 & 3,8 & 5,0 \\
\hline 30. Productos farmacéuticos & 1,7 & 0,3 & 0,3 & 0,3 & 0,5 \\
\hline 31. Abonos & 34,1 & 21,8 & 26,3 & 24,8 & 19,0 \\
\hline 32. Tanino, materias colorantes, pintura & 10,5 & 20,4 & 16,2 & 16,8 & 17,6 \\
\hline 33. Aceites esenciales, preparac. de perfumería & 1,3 & 2,4 & 1,2 & 1,2 & 2,4 \\
\hline 34. Jabones, lubricantes, ceras & 2,7 & 1,9 & 0,8 & 0,8 & 3,1 \\
\hline 35. Materias albuminoideas, colas & 6,5 & 5,0 & 7,0 & 5,1 & 5,1 \\
\hline 36. Pólvoras y explosivos & 82,4 & 18,6 & 13,3 & 73,4 & 74,5 \\
\hline 37. Productos fotográficos o cinematográficos & 0,9 & 0,0 & 0,1 & 0,0 & 1,4 \\
\hline 38. Otros productos químicos & 3,8 & 8,0 & 3,7 & 4,8 & 4,7 \\
\hline 39. Materias plásticas y sus manufacturas & 5,2 & 5,8 & 6,2 & 7,1 & 6,1 \\
\hline 40. Caucho y sus manufacturas & 0,7 & 0,7 & 0,5 & 0,5 & 0,5 \\
\hline 41. Pieles (excepto la peletería) y cueros & 28,5 & 34,3 & 22,7 & 21,1 & 29,6 \\
\hline 42. Manufacturas de cuero, marroquinería & 12,5 & 26,0 & 8,9 & 23,2 & 12,9 \\
\hline 43. Peletería y sus confecciones & 32,3 & 23,6 & 30,7 & 13,5 & 46,7 \\
\hline 44. Madera y sus manufacturas & 7,2 & 7,1 & 7,3 & 8,3 & 11,5 \\
\hline 45. Corcho y sus manufacturas & 4,6 & 3,8 & 14,6 & 7,0 & 8,5 \\
\hline 46. Manufacturas de cestería & 0,9 & 23,8 & 0,6 & 4,8 & 5,7 \\
\hline 47. Pasta de madera, papel reciclado & 0,1 & 0,0 & 0,0 & 0,0 & 0,1 \\
\hline 48. Papel y cartón, sus manufacturas & 2,4 & 2,9 & 4,5 & 2,8 & 5,0 \\
\hline 49. Libros, publicaciones, artes gráficas & 11,2 & 10,6 & 10,3 & 3,6 & 1,3 \\
\hline
\end{tabular}


Comercio exterior de León: Cuota de importaciones sobre Castilla y León (cont.)

\begin{tabular}{|c|c|c|c|c|c|}
\hline Capítulos & 2010 & 2011 & 2012 & 2013 & 2014 \\
\hline 50. Seda & 0,0 & 0,0 & 0,6 & 3,1 & 2,0 \\
\hline 51. Lana y pelo fino & 0,0 & 0,0 & 0,0 & 0,0 & 0,2 \\
\hline 52. Algodón & 4,2 & 1,1 & 1,4 & 7,6 & 10,6 \\
\hline 53. Otras fibras textiles vegetales & 6,0 & 0,0 & 0,0 & 0,3 & 0,5 \\
\hline 54. Filamentos sintéticos o artificiales & 0,3 & 0,5 & 0,6 & 0,8 & 1,9 \\
\hline 55. Fibras sintéticas o artificiales discontinuas & 3,4 & 8,2 & 8,2 & 7,7 & 2,4 \\
\hline 56. Fieltro, tela sin tejer, cordelería & 0,8 & 0,5 & 0,6 & 0,2 & 0,1 \\
\hline 57. Alfombras y revestimientos textiles para el suelo & 24,7 & 5,2 & 5,6 & 14,2 & 6,3 \\
\hline 58. Tejidos especiales, tapicería, bordados & 0,2 & 0,3 & 0,6 & 0,7 & 0,2 \\
\hline 59. Tejidos recubiertos, técnicos de materias textiles & 0,5 & 0,3 & 1,2 & 0,4 & 0,2 \\
\hline 60. Tejidos de punto & 0,5 & 2,0 & 4,5 & 0,0 & 0,5 \\
\hline 61. Prendas de vestir de punto & 15,0 & 16,5 & 16,0 & 16,7 & 14,9 \\
\hline 62. Prendas de vestir, excepto las de punto & 18,2 & 20,0 & 22,5 & 23,5 & 23,9 \\
\hline 63. Demás artículos textiles, prendería & 4,0 & 2,8 & 2,4 & 2,6 & 2,0 \\
\hline 64. Calzado y sus partes & 25,0 & 18,4 & 16,1 & 14,9 & 15,0 \\
\hline 65. Artículos de sombrerería & 12,9 & 22,2 & 18,3 & 16,8 & 16,7 \\
\hline 66. Paraguas, sombrillas, bastones & 0,2 & 0,9 & 1,0 & 4,1 & 6,2 \\
\hline 67. Plumas y plumón preparados & 4,8 & 7,7 & 9,0 & 8,4 & 6,0 \\
\hline 68. Manufacturas de piedra, yeso & 21,3 & 24,8 & 40,4 & 46,4 & 51,4 \\
\hline 69. Productos cerámicos & 22,5 & 17,5 & 15,6 & 16,6 & 16,8 \\
\hline 70. Vidrio y sus manufacturas & 11,7 & 20,4 & 18,1 & 18,7 & 24,2 \\
\hline 71. Piedras y metales preciosos, bisutería & 7,9 & 13,4 & 12,1 & 13,6 & 9,5 \\
\hline 72. Fundición, hierro y acero & 0,5 & 4,0 & 0,6 & 0,7 & 0,5 \\
\hline 73. Manufacturas de fundición, hierro y acero & 1,6 & 2,4 & 1,5 & 3,8 & 2,8 \\
\hline 74. Cobre y sus manufacturas & 61,0 & 65,2 & 83,4 & 80,7 & 75,5 \\
\hline 75. Níquel y sus manufacturas & 0,0 & 0,0 & 0,0 & 1,1 & 0,1 \\
\hline 76. Aluminio y sus manufacturas & 5,0 & 6,7 & 8,7 & 7,3 & 8,6 \\
\hline 78. Plomo y sus manufacturas & 0,1 & 0,0 & 0,0 & 0,0 & 0,0 \\
\hline 79. Cinc y sus manufacturas & 11,8 & 1,4 & 12,5 & 15,5 & 19,3 \\
\hline 80. Estaño y sus manufacturas & 0,1 & 1,7 & 0,4 & 2,0 & 40,4 \\
\hline 81. Demás metales comunes, cermets & 2,0 & 2,3 & 1,3 & 0,2 & 0,4 \\
\hline 82. Herramientas y cuchillos metálicos & 11,5 & 10,9 & 5,6 & 2,0 & 4,4 \\
\hline 83. Manufacturas diversas de metales & 0,3 & 0,2 & 0,3 & 0,5 & 0,7 \\
\hline 84. Máquinas y aparatos mecánicos & 6,5 & 2,0 & 2,1 & 1,9 & 2,2 \\
\hline 85. Máquinas, aparatos y material eléctricos & 7,3 & 2,2 & 1,4 & 5,2 & 2,7 \\
\hline 86. Vehículos, material ferroviarios & 21,4 & 13,9 & 6,3 & 5,9 & 18,8 \\
\hline 87. Vehículos automóviles, tractores & 0,4 & 0,3 & 0,2 & 0,2 & 0,3 \\
\hline 88. Aeronaves, vehículos espaciales & 0,0 & 0,8 & 1,7 & 0,0 & 0,1 \\
\hline 89. Barcos y embarcaciones & 0,0 & 0,0 & 0,0 & 3,3 & 5,3 \\
\hline 90. Aparatos ópticos, de medida, médicos & 8,3 & 6,6 & 8,4 & 6,8 & 6,1 \\
\hline 91. Relojería & 26,9 & 16,2 & 22,3 & 23,5 & 14,2 \\
\hline 92. Instrumentos musicales & 6,9 & 9,2 & 10,1 & 94,2 & 6,9 \\
\hline 93. Armas y municiones, accesorios & 71,5 & 93,3 & 83,6 & 73,6 & 72,7 \\
\hline 94. Muebles, sillas, lámparas & 2,3 & 1,0 & 1,0 & 0,7 & 0,9 \\
\hline 95. Juguetes, juegos, artículos deportivos & 4,8 & 6,5 & 2,0 & 6,1 & 5,0 \\
\hline 96. Manufacturas diversas & 1,7 & 3,8 & 0,7 & 0,7 & 0,8 \\
\hline 97. Objetos de arte, antigüedades & 2,6 & 3,9 & 0,2 & 0,3 & 2,4 \\
\hline 98. Conjuntos industriales & 0,0 & - & - & - & \\
\hline 99. Conjuntos de otros productos & 16,6 & 20,4 & 22,0 & 4,0 & 11,8 \\
\hline TOTAL & 4,9 & 4,1 & 3,6 & 3,4 & 3,3 \\
\hline
\end{tabular}




\section{J.L. Placer Galán}

León. Índice de especialización simétrica respecto a España. 2010-2014

\begin{tabular}{|c|c|c|c|c|c|}
\hline Capítulos & 2010 & 2011 & 2012 & 2013 & 2014 \\
\hline 01. Animales vivos & 0,20 & $-0,94$ & 0,42 & 0,31 & $-0,12$ \\
\hline 02. Carne y despojos comestibles & 0,20 & 0,11 & 0,19 & 0,32 & 0,26 \\
\hline 03. Pescados, crustáceos y moluscos & $-0,69$ & $-0,81$ & $-0,84$ & $-0,89$ & $-0,89$ \\
\hline 04. Leche, productos lácteos, huevos & 0,68 & 0,65 & 0,75 & 0,85 & 0,84 \\
\hline 05. Otros productos de origen animal & $-0,61$ & $-0,62$ & $-0,60$ & $-0,62$ & $-0,69$ \\
\hline 06. Plantas vivas y productos de floricultura & $-1,00$ & $-1,00$ & $-1,00$ & $-1,00$ & $-1,00$ \\
\hline 07. Legumbres, hortalizas & $-0,38$ & $-0,49$ & $-0,54$ & $-0,44$ & $-0,58$ \\
\hline 08. Frutos comestibles & $-0,97$ & $-0,98$ & $-0,96$ & $-0,78$ & $-0,71$ \\
\hline 09. Café, té, yerba mate y especias & $-0,42$ & $-0,58$ & $-0,59$ & $-0,46$ & $-0,59$ \\
\hline 10. Cereales & 0,34 & 0,37 & 0,43 & 0,53 & 0,58 \\
\hline 11. Productos de la molinería, malta & $-1,00$ & $-1,00$ & $-1,00$ & $-0,97$ & $-1,00$ \\
\hline 12. Semillas y frutos oleaginosos & 0,56 & 0,31 & 0,26 & 0,45 & 0,53 \\
\hline 13. Jugos y extractos vegetales & $-0,94$ & $-0,98$ & $-1,00$ & $-1,00$ & $-1,00$ \\
\hline 14. Materias trenzables & $-1,00$ & $-1,00$ & $-1,00$ & $-0,94$ & $-1,00$ \\
\hline 15. Grasas, aceite animal y vegetal & $-1,00$ & $-0,98$ & $-1,00$ & $-0,96$ & $-0,98$ \\
\hline 16. Conservas de carne o pescado & $-0,22$ & $-0,38$ & $-0,43$ & $-0,24$ & $-0,19$ \\
\hline 17. Azúcares, artículos de confitería & $-0,42$ & 0,52 & 0,70 & 0,80 & 0,78 \\
\hline 18. Cacao y sus preparaciones & $-1,00$ & $-1,00$ & $-0,99$ & $-1,00$ & $-1,00$ \\
\hline 19. Productos de cereales, de pastelería & $-0,29$ & $-0,69$ & $-0,94$ & $-0,95$ & $-0,92$ \\
\hline 20. Conservas de verdura o fruta, zumo & $-0,72$ & $-0,69$ & $-0,65$ & $-0,51$ & $-0,55$ \\
\hline 21. Preparaciones alimenticias diversas & 0,67 & 0,56 & 0,44 & 0,48 & 0,43 \\
\hline 22. Bebidas de todo tipo (excluidos zumos) & $-0,51$ & $-0,56$ & $-0,53$ & $-0,41$ & $-0,35$ \\
\hline 23. Residuos de la industria alimentaria & 0,56 & 0,44 & 0,21 & 0,26 & 0,55 \\
\hline 24. Tabaco y sus sucedáneos & $-1,00$ & $-1,00$ & $-1,00$ & $-1,00$ & $-1,00$ \\
\hline 25. Sal, yeso piedras sin trabajar & $-0,10$ & $-0,22$ & $-0,73$ & $-0,74$ & $-0,38$ \\
\hline 26. Minerales, escorias y cenizas & $-0,93$ & $-0,51$ & $-0,41$ & $-0,55$ & $-0,51$ \\
\hline 27. Combustibles, aceites minerales & $-0,66$ & $-0,81$ & $-0,90$ & $-0,89$ & $-0,89$ \\
\hline 28. Productos químicos inorgánicos & $-1,00$ & $-0,84$ & $-1,00$ & $-1,00$ & $-1,00$ \\
\hline 29. Productos químicos orgánicos & 0,32 & 0,11 & $-0,03$ & $-0,73$ & $-1,00$ \\
\hline 30. Productos farmacéuticos & $-0,36$ & $-0,18$ & $-0,11$ & 0,04 & 0,16 \\
\hline 31. Abonos & $-0,84$ & $-1,00$ & $-1,00$ & $-0,95$ & $-0,96$ \\
\hline 32. Tanino, materias colorantes, pintura & $-0,01$ & $-0,19$ & 0,07 & 0,13 & $-0,10$ \\
\hline 33. Aceites esenciales, preparac. de perfumería & $-0,94$ & $-0,98$ & $-0,98$ & $-0,97$ & $-0,97$ \\
\hline 34. Jabones, lubricantes, ceras & $-0,99$ & $-0,96$ & $-0,99$ & $-0,98$ & $-0,85$ \\
\hline 35. Materias albuminoideas, colas & $-0,98$ & $-0,98$ & $-0,99$ & $-0,94$ & $-0,85$ \\
\hline 36. Pólvoras y explosivos & $-1,00$ & $-1,00$ & $-1,00$ & 0,17 & $-0,07$ \\
\hline 37. Productos fotográficos o cinematográficos & $-1,00$ & $-1,00$ & $-0,99$ & $-1,00$ & $-1,00$ \\
\hline 38. Otros productos químicos & $-0,95$ & $-0,92$ & $-0,89$ & $-0,76$ & $-0,73$ \\
\hline 39. Materias plásticas y sus manufacturas & $-0,97$ & $-0,97$ & $-0,92$ & $-0,94$ & $-0,90$ \\
\hline 40. Caucho y sus manufacturas & $-0,44$ & $-0,85$ & $-0,67$ & $-0,48$ & $-0,25$ \\
\hline 41. Pieles (excepto la peletería) y cueros & $-0,03$ & $-0,02$ & $-0,17$ & 0,07 & $-0,28$ \\
\hline 42. Manufacturas de cuero, marroquinería & $-0,96$ & $-0,98$ & $-0,99$ & $-0,90$ & $-0,97$ \\
\hline 43. Peletería y sus confecciones & 0,49 & 0,09 & 0,03 & $-0,23$ & $-0,01$ \\
\hline 44. Madera y sus manufacturas & 0,53 & 0,39 & 0,39 & 0,58 & 0,52 \\
\hline 45. Corcho y sus manufacturas & $-0,99$ & $-1,00$ & $-1,00$ & $-1,00$ & $-0,94$ \\
\hline 46. Manufacturas de cestería & $-0,63$ & $-0,99$ & $-1,00$ & $-1,00$ & $-1,00$ \\
\hline 47. Pasta de madera, papel reciclado & $-0,99$ & $-1,00$ & $-1,00$ & $-1,00$ & $-1,00$ \\
\hline 48. Papel y cartón, sus manufacturas & $-0,97$ & $-0,78$ & $-0,94$ & $-0,97$ & $-0,92$ \\
\hline 49. Libros, publicaciones, artes gráficas & 0,02 & $-0,18$ & $-0,29$ & $-0,22$ & $-0,31$ \\
\hline
\end{tabular}


León. Índice de especialización simétrica respecto a España. 2010-2014 (cont.)

\begin{tabular}{|c|c|c|c|c|c|}
\hline Capítulos & 2010 & 2011 & 2012 & 2013 & 2014 \\
\hline 50. Seda & $-1,00$ & $-1,00$ & $-1,00$ & $-1,00$ & $-1,00$ \\
\hline 51. Lana y pelo fino & $-0,99$ & $-1,00$ & $-1,00$ & $-1,00$ & $-1,00$ \\
\hline 52. Algodón & $-1,00$ & $-0,99$ & $-1,00$ & $-0,99$ & $-0,78$ \\
\hline 53. Otras fibras textiles vegetales & $-1,00$ & $-1,00$ & $-0,99$ & $-1,00$ & $-1,00$ \\
\hline 54. Filamentos sintéticos o artificiales & $-1,00$ & $-0,98$ & $-0,99$ & $-1,00$ & $-0,94$ \\
\hline 55. Fibras sintéticas o artificiales discontinuas & $-1,00$ & $-0,97$ & $-0,95$ & $-0,95$ & $-1,00$ \\
\hline 56. Fieltro, tela sin tejer, cordelería & $-0,99$ & $-0,99$ & $-1,00$ & $-0,98$ & $-0,99$ \\
\hline 57. Alfombras y revestimientos textiles para el suelo & $-1,00$ & $-0,99$ & $-1,00$ & $-1,00$ & $-1,00$ \\
\hline 58. Tejidos especiales, tapicería, bordados & $-1,00$ & $-1,00$ & $-0,94$ & $-1,00$ & $-1,00$ \\
\hline 59. Tejidos recubiertos, técnicos de materias textiles & $-0,99$ & $-1,00$ & $-0,99$ & $-1,00$ & $-1,00$ \\
\hline 60. Tejidos de punto & $-1,00$ & $-1,00$ & $-1,00$ & $-1,00$ & $-1,00$ \\
\hline 61. Prendas de vestir de punto & $-0,98$ & $-0,94$ & $-0,99$ & $-0,73$ & $-0,96$ \\
\hline 62. Prendas de vestir, excepto las de punto & $-0,82$ & $-0,85$ & $-0,88$ & $-0,66$ & $-0,73$ \\
\hline 63. Demás artículos textiles, prendería & $-0,98$ & $-0,99$ & $-0,98$ & $-0,94$ & $-0,92$ \\
\hline 64. Calzado y sus partes & $-0,99$ & $-0,99$ & $-0,99$ & $-0,99$ & $-0,99$ \\
\hline 65. Artículos de sombrerería & $-0,94$ & $-0,97$ & $-0,43$ & $-0,20$ & $-0,45$ \\
\hline 66. Paraguas, sombrillas, bastones & $-0,95$ & $-0,99$ & $-0,96$ & $-0,88$ & $-0,98$ \\
\hline 67. Plumas y plumón preparados & $-1,00$ & $-1,00$ & $-1,00$ & $-1,00$ & $-1,00$ \\
\hline 68. Manufacturas de piedra, yeso & 0,87 & 0,83 & 0,80 & 0,82 & 0,81 \\
\hline 69. Productos cerámicos & $-0,92$ & $-0,95$ & $-0,98$ & $-0,98$ & $-0,97$ \\
\hline 70. Vidrio y sus manufacturas & 0,65 & 0,65 & 0,69 & 0,75 & 0,78 \\
\hline 71. Piedras y metales preciosos, bisutería & $-1,00$ & $-1,00$ & $-1,00$ & $-0,99$ & $-0,97$ \\
\hline 72. Fundición, hierro y acero & 0,75 & 0,56 & 0,59 & 0,64 & 0,67 \\
\hline 73. Manufacturas de fundición, hierro y acero & $-0,11$ & $-0,53$ & $-0,43$ & $-0,32$ & 0,20 \\
\hline 74. Cobre y sus manufacturas & 0,41 & 0,27 & 0,32 & 0,17 & $-0,16$ \\
\hline 75. Níquel y sus manufacturas & $-1,00$ & $-1,00$ & $-1,00$ & $-1,00$ & $-1,00$ \\
\hline 76. Aluminio y sus manufacturas & $-0,62$ & $-0,49$ & $-0,37$ & $-0,59$ & $-0,71$ \\
\hline 78. Plomo y sus manufacturas & $-1,00$ & $-0,55$ & $-1,00$ & $-1,00$ & $-1,00$ \\
\hline 79. Cinc y sus manufacturas & $-0,84$ & $-0,87$ & $-0,88$ & $-0,86$ & $-0,84$ \\
\hline 80. Estaño y sus manufacturas & $-1,00$ & $-1,00$ & $-1,00$ & $-1,00$ & $-0,54$ \\
\hline 81. Demás metales comunes, cermets & $-1,00$ & $-1,00$ & $-0,76$ & $-1,00$ & $-0,69$ \\
\hline 82. Herramientas y cuchillos metálicos & $-0,90$ & $-0,95$ & $-0,82$ & $-0,84$ & $-0,97$ \\
\hline 83. Manufacturas diversas de metales & $-0,77$ & $-0,83$ & $-0,73$ & $-0,73$ & $-0,66$ \\
\hline 84. Máquinas y aparatos mecánicos & $-0,83$ & $-0,47$ & $-0,63$ & $-0,69$ & $-0,27$ \\
\hline 85. Máquinas, aparatos y material eléctricos & 0,66 & 0,79 & 0,80 & 0,79 & 0,75 \\
\hline 86. Vehículos, material ferroviarios & $-0,99$ & $-0,98$ & $-1,00$ & $-1,00$ & $-0,95$ \\
\hline 87. Vehículos automóviles, tractores & $-0,88$ & $-0,94$ & $-0,89$ & $-0,95$ & $-0,96$ \\
\hline 88. Aeronaves, vehículos espaciales & $-1,00$ & $-1,00$ & $-1,00$ & $-1,00$ & $-1,00$ \\
\hline 89. Barcos y embarcaciones & $-1,00$ & $-1,00$ & $-1,00$ & $-1,00$ & $-1,00$ \\
\hline 90. Aparatos ópticos, de medida, médicos & $-0,88$ & $-0,89$ & $-0,84$ & $-0,89$ & $-0,86$ \\
\hline 91. Relojería & $-0,63$ & $-0,57$ & $-0,99$ & $-0,79$ & $-0,71$ \\
\hline 92. Instrumentos musicales & $-1,00$ & $-0,99$ & $-1,00$ & $-1,00$ & $-0,98$ \\
\hline 93. Armas y municiones, accesorios & 0,58 & $-0,54$ & $-0,84$ & 0,62 & 0,55 \\
\hline 94. Muebles, sillas, lámparas & $-0,45$ & $-0,66$ & $-0,84$ & $-0,84$ & $-0,58$ \\
\hline 95. Juguetes, juegos, artículos deportivos & $-0,99$ & $-0,99$ & $-0,94$ & $-0,97$ & $-0,99$ \\
\hline 96. Manufacturas diversas & $-0,89$ & $-0,95$ & $-0,97$ & $-0,99$ & $-0,99$ \\
\hline 97. Objetos de arte, antigüedades & $-1,00$ & $-1,00$ & $-1,00$ & $-1,00$ & $-1,00$ \\
\hline 98. Conjuntos industriales & $-1,00$ & $-1,00$ & $-1,00$ & $-1,00$ & $-1,00$ \\
\hline 99. Conjuntos de otros productos & $-0,95$ & $-0,76$ & $-0,89$ & $-0,99$ & $-0,99$ \\
\hline
\end{tabular}




\section{J.L. Placer Galán}

León. Diferencia interanual de las exportaciones (en miles de euros)

\begin{tabular}{|c|c|c|c|c|}
\hline Capítulos & 2011-2010 & 2012-2011 & 2013-2012 & 2014-2013 \\
\hline TOTAL & $398.948,69$ & $253.633,43$ & $-342.844,48$ & $50.633,31$ \\
\hline 01. Animales vivos & $-2.287,66$ & $7.578,21$ & $-3.011,31$ & $-2.684,17$ \\
\hline 02. Carne y despojos comestibles & $5.124,69$ & $12.923,43$ & $-21,33$ & $-1.408,87$ \\
\hline 03. Pescados, crustáceos y moluscos & $-213,63$ & $-132,55$ & $-647,21$ & 1,22 \\
\hline 04. Leche, productos lácteos, huevos & $3.253,81$ & $21.975,30$ & $17.640,46$ & $2.069,63$ \\
\hline 05. Otros productos de origen animal & 81,93 & 115,76 & $-94,87$ & $-59,62$ \\
\hline 06. Plantas vivas y productos de floricultura & 0,00 & 0,00 & 0,00 & 0,00 \\
\hline 07. Legumbres, hortalizas & $-329,38$ & 706,22 & 817,98 & $-3.054,17$ \\
\hline 08. Frutos comestibles & $-97,62$ & 537,19 & $3.520,94$ & $1.789,68$ \\
\hline 09. Café, té, yerba mate y especias & 52,91 & 104,59 & 46,83 & $-161,68$ \\
\hline 10. Cereales & $1.864,60$ & 835,72 & $1.058,88$ & 466,82 \\
\hline 11. Productos de la molinería, malta & 0,31 & $-0,31$ & 16,93 & $-16,93$ \\
\hline 12. Semillas y frutos oleaginosos & $-711,25$ & 349,32 & $1.045,35$ & $2.141,38$ \\
\hline 13. Jugos y extractos vegetales & $-11,33$ & $-9,73$ & $-0,47$ & 0,33 \\
\hline 14. Materias trenzables & 0,00 & 0,00 & 1,05 & $-1,05$ \\
\hline 15. Grasas, aceite animal y vegetal & 137,56 & $-136,06$ & 291,78 & $-82,58$ \\
\hline 16. Conservas de carne o pescado & 158,59 & 194,34 & 427,52 & 520,69 \\
\hline 17. Azúcares, artículos de confitería & $8.479,51$ & $11.034,43$ & $3.231,25$ & $-1.116,82$ \\
\hline 18. Cacao y sus preparaciones & 0,08 & 11,22 & $-12,81$ & 0,00 \\
\hline 19. Productos de cereales, de pastelería & $-1.099,75$ & $-806,15$ & $-85,08$ & 147,05 \\
\hline 20. Conservas de verdura o fruta, zumo & 835,18 & $1.002,65$ & 500,17 & 21,94 \\
\hline 21. Preparaciones alimenticias diversas & $-391,33$ & $-3.001,54$ & $-3.016,86$ & $-1.336,15$ \\
\hline 22. Bebidas de todo tipo (excluidos zumos) & $1.071,12$ & $2.167,89$ & 755,13 & $1.194,20$ \\
\hline 23. Residuos de la industria alimentaria & 613,44 & $-373,41$ & $-1.692,83$ & $7.740,30$ \\
\hline 24. Tabaco y sus sucedáneos & 0,00 & 0,00 & 0,00 & 0,00 \\
\hline 25. Sal, yeso piedras sin trabajar & 231,96 & $-2.666,11$ & $-290,77$ & $1.928,03$ \\
\hline 26. Minerales, escorias y cenizas & $2.858,60$ & 846,97 & $-1.628,43$ & 352,85 \\
\hline 27. Combustibles, aceites minerales & $-983,19$ & $-2.133,66$ & $-1.565,71$ & 642,24 \\
\hline 28. Productos químicos inorgánicos & 491,03 & $-485,79$ & 4,46 & $-9,44$ \\
\hline 29. Productos químicos orgánicos & $-8.255,01$ & $-2.362,36$ & $-20.875,84$ & $-2.873,25$ \\
\hline 30. Productos farmacéuticos & $19.881,69$ & $15.997,36$ & $-431,65$ & $14.014,05$ \\
\hline 31. Abonos & $-256,92$ & 0,00 & 102,87 & $-22,68$ \\
\hline 32. Tanino, materias colorantes, pintura & $-375,25$ & $8.130,99$ & $-1.857,21$ & $-5.026,65$ \\
\hline 33. Aceites esenciales, preparac. de perfumería & $-148,30$ & 34,71 & 5,89 & 60,13 \\
\hline 34. Jabones, lubricantes, ceras & 107,40 & $-86,48$ & 20,37 & 421,08 \\
\hline 35. Materias albuminóideas, colas & 0,08 & $-2,38$ & 22,64 & 42,42 \\
\hline 36. Pólvoras y explosivos & 0,00 & 0,00 & 481,07 & $-169,78$ \\
\hline 37. Productos fotográficos o cinematográficos & 0,00 & 4,36 & $-4,36$ & 0,00 \\
\hline 38. Otros productos químicos & 212,78 & 512,45 & 844,72 & 372,63 \\
\hline 39. Materias plásticas y sus manufacturas & 265,85 & $1.638,28$ & $-1.060,88$ & $1.073,34$ \\
\hline 40. Caucho y sus manufacturas & $-3.872,63$ & $3.082,33$ & $1.371,60$ & $4.346,52$ \\
\hline 41. Pieles (excepto la peletería) y cueros & $1.422,40$ & $-614,13$ & $1.156,01$ & $-2.409,26$ \\
\hline 42. Manufacturas de cuero, marroquinería & $-5,89$ & $-19,42$ & 176,32 & $-126,31$ \\
\hline 43. Peletería y sus confecciones & $-371,88$ & 85,88 & $-568,91$ & 91,25 \\
\hline 44. Madera y sus manufacturas & 139,78 & $1.617,73$ & $5.228,65$ & $-1.737,04$ \\
\hline 45. Corcho y sus manufacturas & $-4,93$ & 0,44 & $-0,44$ & 35,93 \\
\hline 46. Manufacturas de cestería & $-9,38$ & $-0,27$ & 0,00 & 0,00 \\
\hline 47. Pasta de madera, papel reciclado & $-14,80$ & 0,36 & $-0,33$ & 0,28 \\
\hline 48. Papel y cartón, sus manufacturas & $2.251,31$ & $-1.775,48$ & $-417,58$ & 373,19 \\
\hline 49. Libros, publicaciones, artes gráficas & $-450,28$ & $-274,08$ & $-303,71$ & $-345,90$ \\
\hline
\end{tabular}


León. Diferencia interanual de las exportaciones (cont.)

\begin{tabular}{|c|c|c|c|c|}
\hline 50. Seda & 0,00 & 0,00 & 0,00 & 0,00 \\
\hline 51. Lana y pelo fino & $-1,21$ & 0,00 & 0,00 & 0,00 \\
\hline 52. Algodón & 19,74 & $-18,44$ & 6,33 & 404,07 \\
\hline 53. Otras fibras textiles vegetales & 0,00 & 0,51 & $-0,51$ & 0,00 \\
\hline 54. Filamentos sintéticos o artificiales & 38,32 & $-17,48$ & $-18,73$ & 94,33 \\
\hline 55. Fibras sintéticas o artificiales discontinuas & 32,84 & 25,97 & $-6,96$ & $-49,96$ \\
\hline 56. Fieltro, tela sin tejer, cordelería & 3,80 & $-1,74$ & 9,04 & $-7,23$ \\
\hline 57. Alfombras y revestimientos textiles para el suelo & 1,92 & $-1,92$ & 0,26 & $-0,26$ \\
\hline 58. Tejidos especiales, tapicería, bordados & $-0,51$ & 32,02 & $-32,02$ & 0,72 \\
\hline 59. Tejidos recubiertos, técnicos de materias textiles & $-8,19$ & 14,19 & $-14,44$ & 0,00 \\
\hline 59. Tejidos de punto & 0,00 & 0,00 & 0,00 & 0,99 \\
\hline 61. Prendas de vestir de punto & 407,93 & $-380,57$ & $2.486,17$ & $-2.249,14$ \\
\hline 62. Prendas de vestir, excepto las de punto & 266,34 & 112,52 & $3.252,47$ & $-606,22$ \\
\hline 63. Demás artículos textiles, prendería & $-8,27$ & 6,80 & 49,11 & 49,98 \\
\hline 64. Calzado y sus partes & 20,97 & 7,99 & 7,78 & 31,34 \\
\hline 65. Artículos de sombrerería & 0,81 & 151,52 & 51,80 & $-57,29$ \\
\hline 66. Paraguas, sombrillas, bastones & $-1,85$ & 1,38 & 4,77 & $-5,98$ \\
\hline 67. Plumas y plumón preparados & 0,00 & 0,00 & 0,00 & 0,00 \\
\hline 68. Manufacturas de piedra, yeso & $2.418,47$ & $-4.983,12$ & $-8.269,90$ & $3.157,67$ \\
\hline 69. Productos cerámicos & $-98,71$ & $-161,64$ & $-25,45$ & 92,61 \\
\hline 70. Vidrio y sus manufacturas & $7.279,55$ & $8.414,65$ & $-445,85$ & $8.950,65$ \\
\hline 71. Piedras y metales preciosos, bisutería & 11,90 & $-11,23$ & 105,38 & 30,08 \\
\hline 72. Fundición, hierro y acero & $-57.021,41$ & $29.582,27$ & $-42.812,00$ & $21.559,72$ \\
\hline 73. Manufacturas de fundición, hierro y acero & $-7.611,37$ & $4.764,40$ & $1.177,17$ & $30.823,24$ \\
\hline 74. Cobre y sus manufacturas & $1.482,18$ & $11.856,09$ & $-20.203,84$ & $-7.361,38$ \\
\hline 75. Níquel y sus manufacturas & 0,00 & 0,00 & 0,00 & 0,00 \\
\hline 76. Aluminio y sus manufacturas & $2.557,82$ & $2.697,17$ & $-4.340,75$ & $-956,27$ \\
\hline 78. Plomo y sus manufacturas & 73,14 & $-73,14$ & 0,00 & 0,00 \\
\hline 79. Cinc y sus manufacturas & 5,76 & 0,00 & $-63,93$ & 67,20 \\
\hline 80. Estaño y sus manufacturas & 0,00 & 0,00 & 0,00 & 34,14 \\
\hline 81. Demás metales comunes, cermets & 0,00 & 43,55 & $-43,55$ & 38,66 \\
\hline 82. Herramientas y cuchillos metálicos & $-39,26$ & 339,37 & $-151,14$ & $-228,42$ \\
\hline 83. Manufacturas diversas de metales & $-44,63$ & 542,01 & $-281,83$ & 318,53 \\
\hline 84. Máquinas y aparatos mecánicos & $29.060,17$ & $-7.774,19$ & $-9.154,71$ & $35.865,47$ \\
\hline 85. Máquinas, aparatos y material eléctricos & $391.138,88$ & $128.952,76$ & $-256.612,18$ & $-57.954,07$ \\
\hline 86. Vehículos, material ferroviarios & 25,13 & $-45,24$ & $-2,49$ & 214,10 \\
\hline 87. Vehículos automóviles, tractores & $-2.224,13$ & $5.586,82$ & $-7.972,73$ & $-763,51$ \\
\hline 88. Aeronaves, vehículos espaciales & $-1,36$ & 1,66 & $-1,66$ & 0,00 \\
\hline 89. Barcos y embarcaciones & 0,00 & 0,00 & 0,00 & 0,00 \\
\hline 90. Aparatos ópticos, de medida, médicos & 153,47 & 593,87 & $-632,43$ & 271,68 \\
\hline 91. Relojería & 150,63 & $-401,05$ & 177,16 & 138,12 \\
\hline 92. Instrumentos musicales & 0,94 & $-0,94$ & 0,20 & 1,30 \\
\hline 93. Armas y municiones, accesorios & $-2.910,78$ & $-92,74$ & $3.773,43$ & $-793,16$ \\
\hline 94. Muebles, sillas, lámparas & $-927,70$ & $-1.184,93$ & $-187,01$ & $2.381,24$ \\
\hline 95. Juguetes, juegos, artículos deportivos & 4,50 & 132,98 & $-91,99$ & $-31,69$ \\
\hline 96. Manufacturas diversas & $-42,85$ & $-1,94$ & $-42,69$ & 12,10 \\
\hline 97. Objetos de arte, antigüedades & 0,00 & 1,56 & $-1,56$ & 0,04 \\
\hline 98. Conjuntos industriales & 0,00 & 0,00 & 0,00 & 0,00 \\
\hline 99. Conjuntos de otros productos & $5.089,49$ & $-1.686,52$ & $-3.715,50$ & $-44,96$ \\
\hline
\end{tabular}




\section{J.L. Placer Galán}

León: Tasa de variación anual de las exportaciones

\begin{tabular}{|c|c|c|c|c|c|}
\hline Capítulos & 2010 & 2011 & 2012 & 2013 & 2014 \\
\hline 01. Animales vivos & 46,2 & $-97,0$ & $10.628,8$ & $-39,4$ & $-57,9$ \\
\hline 02. Carne y despojos comestibles & 9,7 & 25,2 & 50,8 & $-0,1$ & $-3,7$ \\
\hline 03. Pescados, crustáceos y moluscos & $-60,4$ & $-12,8$ & $-9,1$ & $-48,9$ & 0,2 \\
\hline 04. Leche, productos lácteos, huevos & 360,0 & 13,5 & 80,3 & 35,7 & 3,1 \\
\hline 05. Otros productos de origen animal & 24,3 & 48,1 & 45,9 & $-25,8$ & $-21,8$ \\
\hline \multicolumn{6}{|l|}{ 06. Plantas vivas y productos de floricultura } \\
\hline 07. Legumbres, hortalizas & 49,1 & $-3,9$ & 8,7 & 9,2 & $-31,5$ \\
\hline 08. Frutos comestibles & 43,8 & $-22,1$ & 155,8 & 399,2 & 40,6 \\
\hline 09. Café, té, yerba mate y especias & $-28,9$ & 10,7 & 19,2 & 7,2 & $-23,2$ \\
\hline 10. Cereales & 65,9 & 52,8 & 15,5 & 17,0 & 6,4 \\
\hline \multicolumn{6}{|l|}{ 11. Productos de la molinería, malta } \\
\hline 12. Semillas y frutos oleaginosos & $-4,8$ & $-12,6$ & 7,1 & 19,8 & 33,9 \\
\hline 13. Jugos y extractos vegetales & $-91,8$ & $-47,6$ & $-78,1$ & $-17,1$ & 14,4 \\
\hline \multicolumn{6}{|l|}{ 14. Materias trenzables } \\
\hline 15. Grasas, aceite animal y vegetal & $-87,9$ & $6.657,9$ & $-97,4$ & $8.188,3$ & $-28,0$ \\
\hline 16. Conservas de carne o pescado & 25,1 & 5,9 & 6,8 & 14,1 & 15,0 \\
\hline 17. Azúcares, artículos de confitería & 369,5 & $1.057,0$ & 118,9 & 15,9 & $-4,7$ \\
\hline 18. Cacao y sus preparaciones & $-99,6$ & 5,3 & 705,3 & $-100,0$ & - \\
\hline 19. Productos de cereales, de pastelería & 73,1 & $-51,4$ & $-77,6$ & $-36,6$ & 99,7 \\
\hline 20. Conservas de verdura o fruta, zumo & $-0,4$ & 54,7 & 42,4 & 14,9 & 0,6 \\
\hline 21. Preparaciones alimenticias diversas & $-29,1$ & $-1,5$ & $-12,1$ & $-13,8$ & $-7,1$ \\
\hline 22. Bebidas de todo tipo (excluidos zumos) & $-7,1$ & 25,4 & 40,9 & 10,1 & 14,5 \\
\hline 23. Residuos de la industria alimentaria & 71,0 & 6,8 & $-3,9$ & $-18,2$ & 101,5 \\
\hline \multicolumn{6}{|l|}{ 24. Tabaco y sus sucedáneos } \\
\hline 25. Sal, yeso piedras sin trabajar & $-18,7$ & 6,4 & $-69,1$ & $-24,3$ & 213,3 \\
\hline 26. Minerales, escorias y cenizas & $-86,5$ & $1.822,6$ & 28,1 & $-42,2$ & 15,8 \\
\hline 27. Combustibles, aceites minerales & $-0,7$ & $-10,6$ & $-25,7$ & $-25,4$ & 14,0 \\
\hline 28. Productos químicos inorgánicos & 263,7 & $166.700,1$ & $-98,9$ & 80,5 & $-94,4$ \\
\hline 29. Productos químicos orgánicos & 2,1 & $-24,0$ & $-9,0$ & $-87,8$ & $-99,4$ \\
\hline 30. Productos farmacéuticos & 72,9 & 107,9 & 41,8 & $-0,8$ & 26,0 \\
\hline 31. Abonos & $2.654,7$ & $-100,0$ & & & $-22,0$ \\
\hline 32. Tanino, materias colorantes, pintura & 18,5 & $-4,5$ & 101,7 & $-11,5$ & $-35,2$ \\
\hline 33. Aceites esenciales, preparac. de perfumería & 20,7 & $-46,5$ & 20,4 & 2,9 & 28,5 \\
\hline 34. Jabones, lubricantes, ceras & $-62,4$ & 731,0 & $-70,8$ & 57,2 & 752,0 \\
\hline 35. Materias albuminoideas, colas & $3.203,1$ & 1,3 & $-38,2$ & 587,3 & 160,1 \\
\hline 36. Pólvoras y explosivos & $-100,0$ & & & & $-35,3$ \\
\hline 37. Productos fotográficos o cinematográficos & & & & $-100,0$ & - \\
\hline 38. Otros productos químicos & 530,7 & 77,8 & 105,4 & 84,6 & 20,2 \\
\hline 39. Materias plásticas y sus manufacturas & 50,8 & 48,8 & 202,1 & $-43,3$ & 77,3 \\
\hline 40. Caucho y sus manufacturas & 10,1 & $-68,8$ & 175,7 & 28,4 & 70,0 \\
\hline 41. Pieles (excepto la peletería) y cueros & 140,6 & 55,9 & $-15,5$ & 34,5 & $-53,4$ \\
\hline 42. Manufacturas de cuero, marroquinería & $-28,8$ & $-12,1$ & $-45,6$ & 761,0 & $-63,3$ \\
\hline 43. Peletería y sus confecciones & 293,3 & $-28,8$ & 9,4 & $-56,6$ & 21,0 \\
\hline 44. Madera y sus manufacturas & 68,7 & 1,0 & 10,9 & 31,8 & $-8,0$ \\
\hline 45. Corcho y sus manufacturas & & $-100,0$ & & $-100,0$ & \\
\hline 46. Manufacturas de cestería & $-69,0$ & $-97,2$ & $-100,0$ & & \\
\hline 47. Pasta de madera, papel reciclado & $-3,7$ & $-99,5$ & 506,5 & $-78,4$ & 307,1 \\
\hline 48. Papel y cartón, sus manufacturas & $-58,5$ & 971,3 & $-71,5$ & $-59,0$ & 128,7 \\
\hline 49. Libros, publicaciones, artes gráficas & $-1,8$ & $-13,3$ & $-9,3$ & $-11,4$ & $-14,7$ \\
\hline
\end{tabular}


León: Tasa de variación anual de las exportaciones (cont.)

\begin{tabular}{|c|c|c|c|c|c|}
\hline Capítulos & 2010 & 2011 & 2012 & 2013 & 2014 \\
\hline \multicolumn{6}{|l|}{ 50. Seda } \\
\hline 51. Lana y pelo fino & & $-100,0$ & & & \\
\hline 52. Algodón & $-71,8$ & 813,4 & $-83,2$ & 169,7 & $4.018,1$ \\
\hline 53. Otras fibras textiles vegetales & & & & $-100,0$ & \\
\hline 54. Filamentos sintéticos o artificiales & $-100,0$ & & $-45,6$ & $-89,8$ & $4.458,6$ \\
\hline 55. Fibras sintéticas o artificiales discontinuas & $-99,8$ & $57.197,1$ & 78,9 & $-11,8$ & $-96,2$ \\
\hline 56. Fieltro, tela sin tejer, cordelería & $-5,6$ & 88,6 & $-21,5$ & 142,5 & $-47,0$ \\
\hline 57. Alfombras y revestimientos textiles para el suelo & $-100,0$ & & $-100,0$ & & \\
\hline 58. Tejidos especiales, tapicería, bordados & $-91,4$ & $-100,0$ & & $-100,0$ & $7.788,8$ \\
\hline 59. Tejidos recubiertos, técnicos de materias textiles & & $-96,6$ & $4.846,2$ & $-99,7$ & $-3,3$ \\
\hline \multicolumn{6}{|l|}{ 60. Tejidos de punto } \\
\hline 61. Prendas de vestir de punto & 28,3 & 344,8 & $-72,3$ & $1.706,5$ & $-85,5$ \\
\hline 62. Prendas de vestir, excepto las de punto & 12,7 & 18,2 & 6,5 & 176,2 & $-11,9$ \\
\hline 63. Demás artículos textiles, prendería & $-83,1$ & $-38,6$ & 51,7 & 246,3 & 72,4 \\
\hline 64. Calzado y sus partes & 84,1 & 60,5 & 14,4 & 12,2 & 43,9 \\
\hline 65. Artículos de sombrerería & $-75,6$ & 12,4 & $2.074,5$ & 32,6 & $-27,2$ \\
\hline 66. Paraguas, sombrillas, bastones & $-93,5$ & $-67,2$ & 153,2 & 209,2 & $-84,8$ \\
\hline 67. Plumas y plumón preparados & $-100,0$ & & & & \\
\hline 68. Manufacturas de piedra, yeso & 6,4 & 3,2 & $-6,4$ & $-11,3$ & 4,9 \\
\hline 69. Productos cerámicos & $-11,1$ & $-22,8$ & $-48,4$ & $-14,8$ & 63,0 \\
\hline 70. Vidrio y sus manufacturas & 42,0 & 34,1 & 29,4 & $-1,2$ & 24,5 \\
\hline 71. Piedras y metales preciosos, bisutería & $-81,8$ & 794,1 & $-83,8$ & $4.857,3$ & 28,0 \\
\hline 72. Fundición, hierro y acero & 85,6 & $-25,5$ & 17,8 & $-21,8$ & 14,1 \\
\hline 73. Manufacturas de fundición, hierro y acero & 200,2 & $-42,4$ & 46,0 & 7,8 & 189,1 \\
\hline 74. Cobre y sus manufacturas & 3,7 & 6,3 & 47,1 & $-54,6$ & $-43,8$ \\
\hline \multicolumn{6}{|l|}{ 75. Níquel y sus manufacturas } \\
\hline 76. Aluminio y sus manufacturas & 139,5 & 109,7 & 55,2 & $-57,2$ & $-29,5$ \\
\hline 78. Plomo y sus manufacturas & & & $-100,0$ & & \\
\hline 79. Cinc y sus manufacturas & $-54,8$ & 2,0 & 0,0 & $-22,0$ & 29,6 \\
\hline \multicolumn{6}{|l|}{ 80. Estaño y sus manufacturas } \\
\hline 81. Demás metales comunes, cermets & $-100,0$ & & & $-100,0$ & \\
\hline 82. Herramientas y cuchillos metálicos & 74,5 & $-28,6$ & 346,9 & $-34,6$ & $-79,9$ \\
\hline 83. Manufacturas diversas de metales & 70,1 & $-7,8$ & 102,4 & $-26,3$ & 40,3 \\
\hline 84. Máquinas y aparatos mecánicos & $-22,0$ & 493,5 & $-22,2$ & $-33,7$ & 199,0 \\
\hline 85. Máquinas, aparatos y material eléctricos & $-6,4$ & 144,2 & 19,5 & $-32,4$ & $-10,8$ \\
\hline 86. Vehículos, material ferroviarios & $-72,0$ & 108,5 & $-93,7$ & $-81,7$ & $38.381,9$ \\
\hline 87. Vehículos automóviles, tractores & 87,5 & $-23,8$ & 78,6 & $-62,8$ & $-16,2$ \\
\hline 88. Aeronaves, vehículos espaciales & & $-100,0$ & & $-100,0$ & \\
\hline \multicolumn{6}{|l|}{ 89. Barcos y embarcaciones } \\
\hline 90. Aparatos ópticos, de medida, médicos & 46,1 & 31,3 & 92,3 & $-51,1$ & 44,9 \\
\hline 91. Relojería & $5.066,8$ & 57,5 & $-97,2$ & $1.528,1$ & 73,2 \\
\hline 92. Instrumentos musicales & & & $-100,0$ & & 650,0 \\
\hline 93. Armas y municiones, accesorios & $-34,9$ & $-94,6$ & $-56,3$ & $5.241,8$ & $-20,6$ \\
\hline 94. Muebles, sillas, lámparas & 20,3 & $-27,6$ & $-48,7$ & $-15,0$ & 224,9 \\
\hline 95. Juguetes, juegos, artículos deportivos & 26,7 & 47,2 & 947,2 & $-62,6$ & $-57,6$ \\
\hline 96. Manufacturas diversas & 66,6 & $-45,2$ & $-3,7$ & $-85,2$ & 163,4 \\
\hline 97. Objetos de arte, antigüedades & & & & $-100,0$ & \\
\hline \multicolumn{6}{|l|}{ 98. Conjuntos industriales } \\
\hline 99. Conjuntos de otros productos & 74,9 & 901,7 & $-29,8$ & $-93,7$ & $-17,8$ \\
\hline TOTAL & 19,9 & 45,4 & 19,9 & $-22,4$ & 4,3 \\
\hline
\end{tabular}


León. Diferencia interanual de las importaciones (en miles de euros)

\begin{tabular}{|c|c|c|c|c|}
\hline Capítulos & 2011-2010 & 2012-2011 & 2013-2012 & 2014-2013 \\
\hline TOTAL & $-24.180,42$ & $-25.483,69$ & $-23.848,45$ & $28.885,62$ \\
\hline 01. Animales vivos & $-2.787,75$ & 780,52 & $-1.610,20$ & 719,69 \\
\hline 02. Carne y despojos comestibles & 859,88 & $-544,33$ & $-1.199,87$ & 48,80 \\
\hline 03. Pescados, crustáceos y moluscos & $-3.909,36$ & $-5.074,75$ & $-1.882,40$ & 910,45 \\
\hline 04. Leche, productos lácteos, huevos & $5.788,96$ & $-2.422,56$ & $-431,52$ & $3.059,29$ \\
\hline 05. Otros productos de origen animal & 297,69 & $-43,46$ & $-83,79$ & 6,77 \\
\hline 06. Plantas vivas y productos de floricultura & 34,13 & $-57,11$ & $-51,00$ & $-7,76$ \\
\hline 07. Legumbres, hortalizas & $-8.166,85$ & $21.157,33$ & $-2.331,03$ & $-17.261,33$ \\
\hline 08. Frutos comestibles & 45,06 & 381,48 & 806,41 & 297,52 \\
\hline 09. Café, té, yerba mate y especias & 100,74 & 277,00 & $-158,91$ & 369,66 \\
\hline 10. Cereales & $4.412,91$ & $4.397,17$ & $-29.740,11$ & $8.303,61$ \\
\hline 11. Productos de la molinería, malta & 287,24 & $2.981,44$ & $-2.543,00$ & $-216,77$ \\
\hline 12. Semillas y frutos oleaginosos & 227,69 & $1.501,48$ & 384,44 & $2.534,09$ \\
\hline 13. Jugos y extractos vegetales & 19,20 & 179,83 & $-85,17$ & 872,28 \\
\hline 14. Materias trenzables & 6,10 & $-6,10$ & 0,23 & 17,04 \\
\hline 15. Grasas, aceite animal y vegetal & 125,41 & $-1.877,80$ & 275,47 & $1.239,44$ \\
\hline 16. Conservas de carne o pescado & $-124,31$ & $-29,28$ & $-281,38$ & 521,85 \\
\hline 17. Azúcares, artículos de confitería & 647,19 & $1.355,55$ & $6.968,37$ & $5.004,31$ \\
\hline 18. Cacao y sus preparaciones & 705,87 & $-534,81$ & $1.255,74$ & $-1.025,78$ \\
\hline 19. Productos de cereales, de pastelería & $-112,02$ & $1.078,54$ & $-35,35$ & $1.810,14$ \\
\hline 20. Conservas de verdura o fruta, zumo & 802,34 & $-624,15$ & $1.670,67$ & 313,50 \\
\hline 21. Preparaciones alimenticias diversas & $-117,85$ & 388,92 & $-348,69$ & 500,49 \\
\hline 22. Bebidas de todo tipo (excluídos zumos) & 169,69 & 140,22 & $-36,56$ & $2.000,23$ \\
\hline 23. Residuos de la industria alimentaria & $-193,81$ & $-1.011,91$ & $-315,20$ & $1.164,51$ \\
\hline 24. Tabaco y sus sucedáneos & 0,00 & 0,00 & 0,00 & 0,00 \\
\hline 25. Sal, yeso piedras sin trabajar & 329,25 & $-545,94$ & $-392,49$ & 103,58 \\
\hline 26. Minerales, escorias y cenizas & 247,47 & $-170,94$ & $-65,07$ & 94,28 \\
\hline 27. Combustibles, aceites minerales & $18.871,98$ & $-18.946,15$ & $2.967,39$ & $2.128,13$ \\
\hline 28. Productos químicos inorgánicos & $-3.231,37$ & $-6.658,12$ & $-1.405,77$ & $-118,69$ \\
\hline 29. Productos químicos orgánicos & $3.904,53$ & $1.195,15$ & $-10.064,73$ & $3.135,46$ \\
\hline 30. Productos farmacéuticos & $-672,46$ & 747,95 & $-485,75$ & 385,50 \\
\hline 31. Abonos & $-1.442,55$ & $2.316,43$ & $-2.656,71$ & $-1.586,15$ \\
\hline 32. Tanino, materias colorantes, pintura & $2.915,71$ & $-871,12$ & $1.154,18$ & $-1.497,28$ \\
\hline 33. Aceites esenciales, preparac. de perfumería & 459,99 & $-428,42$ & 38,78 & 844,38 \\
\hline 34. Jabones, lubricantes, ceras & $-215,69$ & $-216,77$ & $-17,31$ & 375,23 \\
\hline 35. Materias albuminóideas, colas & $-291,03$ & 332,93 & $-214,08$ & 20,49 \\
\hline 36. Pólvoras y explosivos & $-697,11$ & 10,91 & $4.510,70$ & $5.212,68$ \\
\hline 37. Productos fotográficos o cinematográficos & $-9,18$ & 0,21 & $-0,39$ & 1,25 \\
\hline 38. Otros productos químicos & $2.834,58$ & $-2.582,14$ & 89,30 & 9,58 \\
\hline 39. Materias plásticas y sus manufacturas & $3.598,79$ & $-539,29$ & $3.171,41$ & 310,34 \\
\hline 40. Caucho y sus manufacturas & 98,53 & $-992,49$ & $-390,76$ & 239,80 \\
\hline 41. Pieles (excepto la peletería) y cueros & 99,66 & 73,01 & 223,08 & $-761,36$ \\
\hline 42. Manufacturas de cuero, marroquinería & $1.772,23$ & $-2.479,60$ & $2.751,85$ & $-1.424,75$ \\
\hline 43. Peletería y sus confecciones & 108,93 & $-98,49$ & $-104,46$ & $-24,13$ \\
\hline 44. Madera y sus manufacturas & $-249,64$ & $-706,91$ & 191,60 & $1.856,23$ \\
\hline 45. Corcho y sus manufacturas & $-2,39$ & 258,72 & $-198,22$ & 73,57 \\
\hline 46. Manufacturas de cestería & 32,73 & $-32,98$ & 4,74 & 2,23 \\
\hline 47. Pasta de madera, papel reciclado & $-30,91$ & 3,53 & 13,07 & 19,30 \\
\hline 48. Papel y cartón, sus manufacturas & 768,42 & 501,20 & $-1.634,58$ & $2.326,40$ \\
\hline 49. Libros, publicaciones, artes gráficas & $-358,35$ & 233,79 & $-244,83$ & $-244,77$ \\
\hline
\end{tabular}


León. Diferencia interanual de las importaciones (cont.)

\begin{tabular}{|c|c|c|c|c|}
\hline 50. Seda & 0,00 & 2,58 & 5,55 & 0,44 \\
\hline 51. Lana y pelo fino & $-1,00$ & 0,00 & 0,00 & 5,52 \\
\hline 52. Algodón & $-11,51$ & $-0,90$ & 230,47 & 73,00 \\
\hline 53. Otras fibras textiles vegetales & $-5,55$ & 0,00 & 0,11 & 0,05 \\
\hline 54. Filamentos sintéticos o artificiales & 15,49 & 7,47 & 5,77 & 90,86 \\
\hline 55. Fibras sintéticas o artificiales discontinuas & 83,48 & $-30,27$ & 38,74 & $-121,35$ \\
\hline 56. Fieltro, tela sin tejer, cordelería & $-31,45$ & 50,98 & $-115,53$ & $-17,51$ \\
\hline 57. Alfombras y revestimientos textiles para el suelo & $-186,52$ & $-14,00$ & 13,36 & $-22,35$ \\
\hline 58. Tejidos especiales, tapicería, bordados & 8,32 & 3,67 & $-5,84$ & $-10,19$ \\
\hline 59. Tejidos recubiertos, técnicos de materias textiles & $-39,51$ & 147,56 & $-141,88$ & $-43,38$ \\
\hline 59. Tejidos de punto & 21,73 & 27,28 & $-55,82$ & 4,43 \\
\hline 61. Prendas de vestir de punto & $-3,85$ & $-186,63$ & $-394,88$ & 88,62 \\
\hline 62. Prendas de vestir, excepto las de punto & $1.210,14$ & $-1.151,00$ & 173,10 & 856,78 \\
\hline 63. Demás artículos textiles, prendería & $-413,93$ & $-22,90$ & 36,82 & 1,00 \\
\hline 64. Calzado y sus partes & $-444,98$ & $-443,60$ & $-326,89$ & 268,24 \\
\hline 65. Artículos de sombrerería & 31,59 & $-28,97$ & $-4,16$ & 25,59 \\
\hline 66. Paraguas, sombrillas, bastones & 11,24 & $-17,01$ & 4,05 & 9,07 \\
\hline 67. Plumas y plumón preparados & 21,61 & 0,89 & $-15,08$ & $-4,02$ \\
\hline 68. Manufacturas de piedra, yeso & 297,85 & $1.839,52$ & $-778,09$ & 351,80 \\
\hline 69. Productos cerámicos & $-411,93$ & $-877,71$ & 300,67 & 439,72 \\
\hline 70. Vidrio y sus manufacturas & $6.305,54$ & $-2.203,08$ & 247,19 & $4.258,41$ \\
\hline 71. Piedras y metales preciosos, bisutería & 28,69 & $-113,22$ & 12,89 & 45,73 \\
\hline 72. Fundición, hierro y acero & $16.906,61$ & $-16.554,93$ & 260,23 & $-651,62$ \\
\hline 73. Manufacturas de fundición, hierro y acero & $1.663,70$ & 286,96 & $4.843,05$ & $-3.715,26$ \\
\hline 74. Cobre y sus manufacturas & $3.310,42$ & $11.740,73$ & $-11.884,74$ & $-1.413,54$ \\
\hline 75. Níquel y sus manufacturas & $-0,04$ & 0,06 & 13,49 & $-13,67$ \\
\hline 76. Aluminio y sus manufacturas & 631,82 & 818,65 & $-88,00$ & 511,91 \\
\hline 78. Plomo y sus manufacturas & $-37,78$ & 0,00 & 0,00 & 0,00 \\
\hline 79. Cinc y sus manufacturas & $-193,79$ & 171,54 & 57,95 & 105,87 \\
\hline 80. Estaño y sus manufacturas & 7,83 & $-7,95$ & $-0,86$ & 520,05 \\
\hline 81. Demás metales comunes, cermets & 64,58 & $-87,51$ & $-82,56$ & 17,28 \\
\hline 82. Herramientas y cuchillos metálicos & 92,08 & $-342,94$ & $-295,17$ & 460,63 \\
\hline 83. Manufacturas diversas de metales & $-77,33$ & 58,39 & 72,19 & 78,87 \\
\hline 84. Máquinas y aparatos mecánicos & $-52.292,02$ & $-3.271,81$ & $1.461,22$ & $7.250,77$ \\
\hline 85. Máquinas, aparatos y material eléctricos & $-26.556,65$ & $-3.574,17$ & $17.040,34$ & $-8.469,20$ \\
\hline 86. Vehículos, material ferroviarios & 189,24 & $-207,21$ & $-208,53$ & 9,20 \\
\hline 87. Vehículos automóviles, tractores & $-949,69$ & $-3.343,94$ & $1.960,84$ & $4.816,57$ \\
\hline 88. Aeronaves, vehículos espaciales & 19,10 & 40,13 & $-59,23$ & 2,10 \\
\hline 89. Barcos y embarcaciones & 0,00 & 0,00 & 0,88 & 5,76 \\
\hline 90. Aparatos ópticos, de medida, médicos & $-61,68$ & 872,74 & $-31,26$ & $1.128,65$ \\
\hline 91. Relojería & 52,17 & 47,20 & 174,13 & $-186,24$ \\
\hline 92. Instrumentos musicales & 1,17 & $-2,69$ & $1.224,31$ & $-1.226,16$ \\
\hline 93. Armas y municiones, accesorios & $-1.828,90$ & $-150,82$ & $1.185,63$ & 61,01 \\
\hline 94. Muebles, sillas, lámparas & $-1.007,37$ & $-319,25$ & $-253,64$ & 315,75 \\
\hline 95. Juguetes, juegos, artículos deportivos & 72,15 & $-148,85$ & 48,37 & $-4,61$ \\
\hline 96. Manufacturas diversas & 103,91 & $-60,76$ & $-36,71$ & 60,56 \\
\hline 97. Objetos de arte, antigüedades & $-18,84$ & 2,18 & $-5,63$ & 2,51 \\
\hline 98. Conjuntos industriales & 0,00 & 0,00 & 0,00 & 0,00 \\
\hline 99. Conjuntos de otros productos & $1.283,11$ & $-1.237,81$ & $-5.943,36$ & 254,61 \\
\hline
\end{tabular}




\section{J.L. Placer Galán}

Índice simétrico de dependencia de las importaciones de León respecto a España. 2010-2014

\begin{tabular}{|c|c|c|c|c|c|}
\hline Capítulos & 2010 & 2011 & 2012 & 2013 & 2014 \\
\hline 01. Animales vivos & 0,83 & 0,77 & 0,81 & 0,70 & 0,71 \\
\hline 02. Carne y despojos comestibles & 0,20 & 0,36 & 0,31 & 0,11 & 0,12 \\
\hline 03. Pescados, crustáceos y moluscos & 0,48 & 0,45 & 0,37 & 0,34 & 0,32 \\
\hline 04. Leche, productos lácteos, huevos & 0,44 & 0,66 & 0,61 & 0,61 & 0,67 \\
\hline 05. Otros productos de origen animal & 0,03 & 0,36 & 0,34 & 0,23 & 0,24 \\
\hline 06. Plantas vivas y productos de floricultura & 0,05 & 0,17 & 0,13 & 0,10 & $-0,01$ \\
\hline 07. Legumbres, hortalizas & 0,96 & 0,96 & 0,97 & 0,97 & 0,96 \\
\hline 08. Frutos comestibles & $-0,24$ & $-0,18$ & $-0,07$ & 0,04 & 0,02 \\
\hline 09. Café, té, yerba mate y especias & $-0,38$ & $-0,38$ & $-0,20$ & $-0,19$ & $-0,13$ \\
\hline 10. Cereales & 0,76 & 0,76 & 0,76 & 0,09 & 0,55 \\
\hline 11. Productos de la molinería, malta & $-1,00$ & 0,02 & 0,84 & 0,43 & 0,24 \\
\hline 12. Semillas y frutos oleaginosos & 0,47 & 0,48 & 0,48 & 0,54 & 0,60 \\
\hline 13. Jugos y extractos vegetales & $-0,12$ & $-0,06$ & 0,25 & 0,13 & 0,68 \\
\hline 14. Materias trenzables & $-1,00$ & $-0,76$ & $-1,00$ & $-0,98$ & $-0,26$ \\
\hline 15. Grasas, aceite animal y vegetal & 0,03 & 0,06 & $-0,53$ & $-0,45$ & $-0,08$ \\
\hline 16. Conservas de carne o pescado & $-0,46$ & $-0,54$ & $-0,58$ & $-0,85$ & $-0,40$ \\
\hline 17. Azúcares, artículos de confitería & $-0,54$ & $-0,28$ & 0,25 & 0,72 & 0,83 \\
\hline 18. Cacao y sus preparaciones & $-0,99$ & $-0,31$ & $-0,74$ & 0,11 & $-0,53$ \\
\hline 19. Productos de cereales, de pastelería & $-0,51$ & $-0,51$ & $-0,01$ & 0,00 & 0,35 \\
\hline 20. Conservas de verdura o fruta, zumo & 0,32 & 0,43 & 0,38 & 0,55 & 0,54 \\
\hline 21. Preparaciones alimenticias diversas & $-0,70$ & $-0,75$ & $-0,49$ & $-0,67$ & $-0,28$ \\
\hline 22. Bebidas de todo tipo (excluidos zumos) & $-0,97$ & $-0,86$ & $-0,77$ & $-0,78$ & $-0,05$ \\
\hline 23. Residuos de la industria alimentaria & 0,47 & 0,49 & 0,37 & 0,38 & 0,42 \\
\hline 24. Tabaco y sus sucedáneos & $-1,00$ & $-1,00$ & $-1,00$ & $-1,00$ & $-1,00$ \\
\hline 25. Sal, yeso piedras sin trabajar & $-0,08$ & 0,18 & $-0,06$ & $-0,51$ & $-0,39$ \\
\hline 26. Minerales, escorias y cenizas & $-0,99$ & $-0,92$ & $-0,96$ & $-0,98$ & $-0,95$ \\
\hline 27. Combustibles, aceites minerales & $-0,96$ & $-0,63$ & $-0,97$ & $-0,90$ & $-0,85$ \\
\hline 28. Productos químicos inorgánicos & 0,57 & 0,48 & $-0,16$ & $-0,50$ & $-0,55$ \\
\hline 29. Productos químicos orgánicos & 0,10 & 0,24 & 0,29 & $-0,02$ & 0,09 \\
\hline 30. Productos farmacéuticos & $-0,81$ & $-0,85$ & $-0,78$ & $-0,81$ & $-0,78$ \\
\hline 31. Abonos & 0,77 & 0,71 & 0,75 & 0,67 & 0,55 \\
\hline 32. Tanino, materias colorantes, pintura & 0,18 & 0,44 & 0,47 & 0,55 & 0,45 \\
\hline 33. Aceites esenciales, preparac. de perfumería & $-0,77$ & $-0,56$ & $-0,71$ & $-0,71$ & $-0,45$ \\
\hline 34. Jabones, lubricantes, ceras & $-0,41$ & $-0,54$ & $-0,79$ & $-0,80$ & $-0,42$ \\
\hline 35. Materias albuminoideas, colas & 0,18 & 0,08 & 0,26 & 0,16 & 0,13 \\
\hline 36. Pólvoras y explosivos & 0,87 & $-0,39$ & $-0,13$ & 0,98 & 0,99 \\
\hline 37. Productos fotográficos o cinematográficos & $-0,96$ & $-1,00$ & $-1,00$ & $-1,00$ & $-0,99$ \\
\hline 38. Otros productos químicos & $-0,58$ & $-0,20$ & $-0,53$ & $-0,43$ & $-0,40$ \\
\hline 39. Materias plásticas y sus manufacturas & $-0,01$ & 0,15 & 0,18 & 0,26 & 0,22 \\
\hline 40. Caucho y sus manufacturas & $-0,26$ & $-0,27$ & $-0,34$ & $-0,37$ & $-0,32$ \\
\hline 41. Pieles (excepto la peletería) y cueros & 0,13 & 0,11 & 0,18 & 0,23 & $-0,21$ \\
\hline 42. Manufacturas de cuero, marroquinería & $-0,18$ & 0,26 & $-0,41$ & 0,34 & 0,03 \\
\hline 43. Peletería y sus confecciones & 0,40 & 0,64 & 0,53 & 0,32 & 0,25 \\
\hline 44. Madera y sus manufacturas & 0,25 & 0,34 & 0,34 & 0,39 & 0,53 \\
\hline 45. Corcho y sus manufacturas & $-0,19$ & $-0,21$ & 0,45 & 0,09 & 0,21 \\
\hline 46. Manufacturas de cestería & $-0,98$ & $-0,32$ & $-0,98$ & $-0,78$ & $-0,75$ \\
\hline 47. Pasta de madera, papel reciclado & $-0,95$ & $-1,00$ & $-0,99$ & $-0,97$ & $-0,93$ \\
\hline 48. Papel y cartón, sus manufacturas & $-0,28$ & $-0,14$ & 0,00 & $-0,18$ & 0,06 \\
\hline 49. Libros, publicaciones, artes gráficas & $-0,10$ & $-0,31$ & $-0,08$ & $-0,21$ & $-0,59$ \\
\hline
\end{tabular}


Índice simétrico de dependencia de las importaciones de León respecto a España. 2010-2014 (cont.)

\begin{tabular}{|c|c|c|c|c|c|}
\hline Capítulos & 2010 & 2011 & 2012 & 2013 & 2014 \\
\hline 50. Seda & $-1,00$ & $-1,00$ & $-0,90$ & $-0,56$ & $-0,45$ \\
\hline 51. Lana y pelo fino & $-0,99$ & $-1,00$ & $-1,00$ & $-1,00$ & $-0,92$ \\
\hline 52. Algodón & $-0,86$ & $-0,87$ & $-0,85$ & $-0,36$ & $-0,29$ \\
\hline 53. Otras fibras textiles vegetales & $-0,89$ & $-1,00$ & $-1,00$ & $-1,00$ & $-1,00$ \\
\hline 54. Filamentos sintéticos o artificiales & $-0,93$ & $-0,90$ & $-0,88$ & $-0,87$ & $-0,74$ \\
\hline 55. Fibras sintéticas o artificiales discontinuas & $-0,66$ & $-0,49$ & $-0,49$ & $-0,51$ & $-0,74$ \\
\hline 56. Fieltro, tela sin tejer, cordelería & $-0,53$ & $-0,57$ & $-0,43$ & $-0,74$ & $-0,82$ \\
\hline 57. Alfombras y revestimientos textiles para el suelo & $-0,01$ & $-0,53$ & $-0,58$ & $-0,48$ & $-0,69$ \\
\hline 58. Tejidos especiales, tapicería, bordados & $-0,91$ & $-0,82$ & $-0,78$ & $-0,80$ & $-0,93$ \\
\hline 59. Tejidos recubiertos, técnicos de materias textiles & $-0,56$ & $-0,65$ & $-0,22$ & $-0,63$ & $-0,80$ \\
\hline 60. Tejidos de punto & $-0,95$ & $-0,80$ & $-0,65$ & $-1,00$ & $-0,97$ \\
\hline 61. Prendas de vestir de punto & $-0,42$ & $-0,38$ & $-0,39$ & $-0,42$ & $-0,46$ \\
\hline 62. Prendas de vestir, excepto las de punto & $-0,27$ & $-0,14$ & $-0,22$ & $-0,19$ & $-0,19$ \\
\hline 63. Demás artículos textiles, prendería & $-0,44$ & $-0,76$ & $-0,75$ & $-0,71$ & $-0,75$ \\
\hline 64. Calzado y sus partes & $-0,29$ & $-0,33$ & $-0,42$ & $-0,51$ & $-0,49$ \\
\hline 65. Artículos de sombrerería & $-0,40$ & $-0,22$ & $-0,27$ & $-0,28$ & $-0,30$ \\
\hline 66. Paraguas, sombrillas, bastones & $-0,84$ & $-0,66$ & $-0,85$ & $-0,77$ & $-0,69$ \\
\hline 67. Plumas y plumón preparados & $-0,57$ & $-0,20$ & $-0,18$ & $-0,29$ & $-0,43$ \\
\hline 68. Manufacturas de piedra, yeso & 0,44 & 0,55 & 0,76 & 0,73 & 0,71 \\
\hline 69. Productos cerámicos & 0,51 & 0,56 & 0,46 & 0,54 & 0,55 \\
\hline 70. Vidrio y sus manufacturas & 0,52 & 0,74 & 0,74 & 0,75 & 0,79 \\
\hline 71. Piedras y metales preciosos, bisutería & $-0,54$ & $-0,66$ & $-0,74$ & $-0,66$ & $-0,60$ \\
\hline 72. Fundición, hierro y acero & $-0,77$ & 0,12 & $-0,69$ & $-0,62$ & $-0,73$ \\
\hline 73. Manufacturas de fundición, hierro y acero & $-0,27$ & $-0,03$ & 0,05 & 0,40 & 0,14 \\
\hline 74. Cobre y sus manufacturas & 0,72 & 0,75 & 0,87 & 0,82 & 0,81 \\
\hline 75. Níquel y sus manufacturas & $-1,00$ & $-1,00$ & $-1,00$ & $-0,94$ & $-1,00$ \\
\hline 76. Aluminio y sus manufacturas & $-0,02$ & 0,09 & 0,23 & 0,23 & 0,23 \\
\hline 78. Plomo y sus manufacturas & $-0,83$ & $-1,00$ & $-1,00$ & $-1,00$ & $-1,00$ \\
\hline 79. Cinc y sus manufacturas & 0,26 & $-0,68$ & 0,40 & 0,56 & 0,53 \\
\hline 80. Estaño y sus manufacturas & $-0,99$ & $-0,93$ & $-0,98$ & $-0,99$ & 0,47 \\
\hline 81. Demás metales comunes, cermets & $-0,32$ & $-0,12$ & $-0,38$ & $-0,89$ & $-0,75$ \\
\hline 82. Herramientas y cuchillos metálicos & $-0,12$ & $-0,02$ & $-0,16$ & $-0,39$ & $-0,12$ \\
\hline 83. Manufacturas diversas de metales & $-0,81$ & $-0,86$ & $-0,78$ & $-0,70$ & $-0,66$ \\
\hline 84. Máquinas y aparatos mecánicos & 0,31 & $-0,16$ & $-0,18$ & $-0,13$ & $-0,05$ \\
\hline 85. Máquinas, aparatos y material eléctricos & $-0,04$ & $-0,55$ & $-0,64$ & $-0,05$ & $-0,32$ \\
\hline 86. Vehículos, material ferroviarios & $-0,15$ & 0,28 & 0,16 & $-0,18$ & $-0,18$ \\
\hline 87. Vehículos automóviles, tractores & $-0,56$ & $-0,58$ & $-0,63$ & $-0,58$ & $-0,51$ \\
\hline 88. Aeronaves, vehículos espaciales & $-1,00$ & $-0,98$ & $-0,96$ & $-1,00$ & $-1,00$ \\
\hline 89. Barcos y embarcaciones & $-1,00$ & $-1,00$ & $-1,00$ & $-0,99$ & $-0,97$ \\
\hline 90. Aparatos ópticos, de medida, médicos & $-0,42$ & $-0,36$ & $-0,23$ & $-0,23$ & $-0,19$ \\
\hline 91. Relojería & $-0,54$ & $-0,45$ & $-0,40$ & $-0,23$ & $-0,45$ \\
\hline 92. Instrumentos musicales & $-0,92$ & $-0,88$ & $-0,91$ & 0,82 & $-0,93$ \\
\hline 93. Armas y municiones, accesorios & 0,91 & 0,92 & 0,95 & 0,96 & 0,97 \\
\hline 94. Muebles, sillas, lámparas & $-0,37$ & $-0,46$ & $-0,48$ & $-0,54$ & $-0,52$ \\
\hline 95. Juguetes, juegos, artículos deportivos & $-0,86$ & $-0,79$ & $-0,86$ & $-0,82$ & $-0,85$ \\
\hline 96. Manufacturas diversas & $-0,55$ & $-0,36$ & $-0,54$ & $-0,58$ & $-0,55$ \\
\hline 97. Objetos de arte, antigüedades & $-0,62$ & $-0,92$ & $-0,83$ & $-0,92$ & $-0,88$ \\
\hline 98. Conjuntos industriales & $-1,00$ & $-1,00$ & $-1,00$ & $-1,00$ & $-1,00$ \\
\hline 99. Conjuntos de otros productos & 0,57 & 0,60 & 0,56 & $-0,02$ & 0,38 \\
\hline
\end{tabular}




\section{J.L. Placer Galán}

León. Saldo comercial relativo. 2010-2014

\begin{tabular}{|c|c|c|c|c|c|}
\hline Capítulos & 2010 & 2011 & 2012 & 2013 & 2014 \\
\hline 01. Animales vivos & $-0,48$ & $-0,96$ & 0,23 & 0,19 & $-0,33$ \\
\hline 02. Carne y despojos comestibles & 0,74 & 0,74 & 0,84 & 0,89 & 0,89 \\
\hline 03. Pescados, crustáceos y moluscos & $-0,86$ & $-0,86$ & $-0,83$ & $-0,89$ & $-0,90$ \\
\hline 04. Leche, productos lácteos, huevos & 0,49 & 0,32 & 0,62 & 0,71 & 0,66 \\
\hline 05. Otros productos de origen animal & $-0,28$ & $-0,41$ & $-0,20$ & $-0,27$ & $-0,38$ \\
\hline 06. Plantas vivas y productos de floricultura & $-1,00$ & $-1,00$ & $-1,00$ & $-1,00$ & $-1,00$ \\
\hline 07. Legumbres, hortalizas & $-0,80$ & $-0,78$ & $-0,82$ & $-0,80$ & $-0,82$ \\
\hline 08. Frutos comestibles & $-0,58$ & $-0,67$ & $-0,41$ & 0,21 & 0,32 \\
\hline 09. Café, té, yerba mate y especias & $-0,09$ & $-0,12$ & $-0,20$ & $-0,08$ & $-0,38$ \\
\hline 10. Cereales & $-0,75$ & $-0,69$ & $-0,69$ & 0,28 & $-0,23$ \\
\hline 11. Productos de la molinería, malta & - & $-1,00$ & $-1,00$ & $-0,95$ & $-1,00$ \\
\hline 12. Semillas y frutos oleaginosos & $-0,19$ & $-0,26$ & $-0,31$ & $-0,24$ & $-0,21$ \\
\hline 13. Jugos y extractos vegetales & $-0,75$ & $-0,87$ & $-0,99$ & $-0,98$ & $-1,00$ \\
\hline 14. Materias trenzables & - & $-1,00$ & -1 & 0,64 & $-1,00$ \\
\hline 15. Grasas, aceite animal y vegetal & $-1,00$ & $-0,90$ & $-0,99$ & $-0,53$ & $-0,82$ \\
\hline 16. Conservas de carne o pescado & 0,65 & 0,73 & 0,76 & 0,93 & 0,72 \\
\hline 17. Azúcares, artículos de confitería & 0,42 & 0,81 & 0,79 & 0,43 & 0,22 \\
\hline 18. Cacao y sus preparaciones & $-0,66$ & $-1,00$ & $-0,87$ & $-1,00$ & $-1,00$ \\
\hline 19. Productos de cereales, de pastelería & 0,54 & 0,32 & $-0,75$ & $-0,83$ & $-0,84$ \\
\hline 20. Conservas de verdura o fruta, zumo & $-0,29$ & $-0,21$ & 0,06 & $-0,09$ & $-0,12$ \\
\hline 21. Preparaciones alimenticias diversas & 0,97 & 0,97 & 0,94 & 0,96 & 0,91 \\
\hline 22. Bebidas de todo tipo (excluidos zumos) & 0,98 & 0,92 & 0,91 & 0,92 & 0,60 \\
\hline 23. Residuos de la industria alimentaria & 0,16 & 0,21 & 0,27 & 0,20 & 0,42 \\
\hline 24. Tabaco y sus sucedáneos & - & - & - & - & - \\
\hline 25. Sal, yeso piedras sin trabajar & 0,63 & 0,54 & 0,33 & 0,62 & 0,80 \\
\hline 26. Minerales, escorias y cenizas & 0,53 & 0,82 & 0,94 & 0,95 & 0,89 \\
\hline 27. Combustibles, aceites minerales & 0,69 & $-0,42$ & 0,58 & 0,00 & $-0,12$ \\
\hline 28. Productos químicos inorgánicos & $-1,00$ & $-0,90$ & $-1,00$ & $-0,98$ & $-1,00$ \\
\hline 29. Productos químicos orgánicos & 0,35 & 0,12 & 0,04 & $-0,60$ & $-1,00$ \\
\hline 30. Productos farmacéuticos & 0,79 & 0,93 & 0,92 & 0,94 & 0,94 \\
\hline 31. Abonos & $-0,94$ & $-1,00$ & $-1,00$ & $-0,97$ & $-0,97$ \\
\hline 32. Tanino, materias colorantes, pintura & 0,34 & 0,07 & 0,45 & 0,32 & 0,23 \\
\hline 33. Aceites esenciales, preparac. de perfumería & $-0,24$ & $-0,70$ & $-0,46$ & $-0,47$ & $-0,68$ \\
\hline 34. Jabones, lubricantes, ceras & $-0,95$ & $-0,50$ & $-0,61$ & $-0,39$ & $-0,03$ \\
\hline 35. Materias albuminoideas, colas & $-0,99$ & $-0,99$ & $-0,99$ & $-0,95$ & $-0,88$ \\
\hline 36. Pólvoras y explosivos & $-1,00$ & $-1,00$ & $-1,00$ & $-0,81$ & $-0,94$ \\
\hline 37. Productos fotográficos o cinematográficos & $-1,00$ & $-1,00$ & 0,82 & $-1,00$ & $-1,00$ \\
\hline 38. Otros productos químicos & $-0,73$ & $-0,81$ & $-0,33$ & $-0,06$ & 0,03 \\
\hline 39. Materias plásticas y sus manufacturas & $-0,92$ & $-0,91$ & $-0,74$ & $-0,87$ & $-0,78$ \\
\hline 40. Caucho y sus manufacturas & 0,22 & $-0,36$ & 0,28 & 0,45 & 0,61 \\
\hline 41. Pieles (excepto la peletería) y cueros & 0,41 & 0,54 & 0,46 & 0,51 & 0,49 \\
\hline 42. Manufacturas de cuero, marroquinería & $-0,94$ & $-0,97$ & $-0,94$ & $-0,89$ & $-0,93$ \\
\hline 43. Peletería y sus confecciones & 0,72 & 0,48 & 0,64 & 0,57 & 0,69 \\
\hline 44. Madera y sus manufacturas & 0,56 & 0,59 & 0,68 & 0,73 & 0,59 \\
\hline 45. Corcho y sus manufacturas & $-0,91$ & $-1,00$ & $-1,00$ & $-1,00$ & $-0,74$ \\
\hline 46. Manufacturas de cestería & 0,82 & $-0,98$ & $-1,00$ & $-1,00$ & $-1,00$ \\
\hline 47. Pasta de madera, papel reciclado & $-0,37$ & $-0,90$ & $-0,84$ & $-0,99$ & $-0,98$ \\
\hline 48. Papel y cartón, sus manufacturas & $-0,88$ & $-0,27$ & $-0,74$ & $-0,83$ & $-0,79$ \\
\hline 49. Libros, publicaciones, artes gráficas & 0,61 & 0,73 & 0,58 & 0,68 & 0,81 \\
\hline
\end{tabular}


León. Saldo comercial relativo. 2010-2014 (cont.)

\begin{tabular}{|c|c|c|c|c|c|}
\hline Capítulos & 2010 & 2011 & 2012 & 2013 & 2014 \\
\hline 50. Seda & - & & $-1,00$ & $-1,00$ & $-1,00$ \\
\hline 51. Lana y pelo fino & 0,10 & & & & $-1,00$ \\
\hline 52. Algodón & $-0,93$ & $-0,43$ & $-0,87$ & $-0,93$ & 0,07 \\
\hline 53. Otras fibras textiles vegetales & $-1,00$ & & 1,00 & $-1,00$ & $-1,00$ \\
\hline 54. Filamentos sintéticos o artificiales & $-1,00$ & $-0,07$ & $-0,42$ & $-0,93$ & $-0,21$ \\
\hline 55. Fibras sintéticas o artificiales discontinuas & $-1,00$ & $-0,77$ & $-0,58$ & $-0,67$ & $-0,97$ \\
\hline 56. Fieltro, tela sin tejer, cordelería & $-0,95$ & $-0,88$ & $-0,93$ & $-0,62$ & $-0,72$ \\
\hline 57. Alfombras y revestimientos textiles para el suelo & $-1,00$ & $-0,94$ & $-1,00$ & $-0,99$ & $-1,00$ \\
\hline 58. Tejidos especiales, tapicería, bordados & $-0,90$ & $-1,00$ & 0,19 & $-1,00$ & $-0,77$ \\
\hline 59. Tejidos recubiertos, técnicos de materias textiles & $-0,87$ & $-0,99$ & $-0,88$ & $-1,00$ & $-1,00$ \\
\hline 60. Tejidos de punto & $-1,00$ & $-1,00$ & $-1,00$ & $-1,00$ & $-0,64$ \\
\hline 61. Prendas de vestir de punto & $-0,94$ & $-0,74$ & $-0,92$ & $-0,07$ & $-0,78$ \\
\hline 62. Prendas de vestir, excepto las de punto & $-0,59$ & $-0,60$ & $-0,52$ & $-0,08$ & $-0,21$ \\
\hline 63. Demás artículos textiles, prendería & $-0,93$ & $-0,87$ & $-0,79$ & $-0,49$ & $-0,26$ \\
\hline 64. Calzado y sus partes & $-0,97$ & $-0,94$ & $-0,91$ & $-0,87$ & $-0,85$ \\
\hline 65. Artículos de sombrerería & $-0,88$ & $-0,89$ & 0,22 & 0,37 & 0,11 \\
\hline 66. Paraguas, sombrillas, bastones & $-0,65$ & $-0,93$ & $-0,53$ & $-0,24$ & $-0,90$ \\
\hline 67. Plumas y plumón preparados & $-1,00$ & $-1,00$ & $-1,00$ & $-1,00$ & $-1,00$ \\
\hline 68. Manufacturas de piedra, yeso & 0,94 & 0,94 & 0,89 & 0,89 & 0,89 \\
\hline 69. Productos cerámicos & $-0,74$ & $-0,76$ & $-0,80$ & $-0,86$ & $-0,81$ \\
\hline 70. Vidrio y sus manufacturas & 0,50 & 0,36 & 0,54 & 0,53 & 0,49 \\
\hline 71. Piedras y metales preciosos, bisutería & $-0,99$ & $-0,95$ & $-0,99$ & $-0,58$ & $-0,54$ \\
\hline 72. Fundición, hierro y acero & 0,98 & 0,80 & 0,98 & 0,97 & 0,98 \\
\hline 73. Manufacturas de fundición, hierro y acero & 0,69 & 0,35 & 0,48 & 0,24 & 0,76 \\
\hline 74. Cobre y sus manufacturas & 0,19 & 0,13 & 0,09 & $-0,07$ & $-0,31$ \\
\hline 75. Níquel y sus manufacturas & $-1,00$ & $-1,00$ & $-1,00$ & $-1,00$ & $-1,00$ \\
\hline 76. Aluminio y sus manufacturas & $-0,21$ & 0,08 & 0,21 & $-0,20$ & $-0,41$ \\
\hline 78. Plomo y sus manufacturas & $-1,00$ & 1,00 & & & \\
\hline 79. Cinc y sus manufacturas & 0,13 & 0,84 & 0,19 & $-0,06$ & $-0,10$ \\
\hline 80. Estaño y sus manufacturas & $-1,00$ & $-1,00$ & $-1,00$ & $-1,00$ & $-0,88$ \\
\hline 81. Demás metales comunes, cermets & $-1,00$ & $-1,00$ & $-0,37$ & $-1,00$ & 0,14 \\
\hline 82. Herramientas y cuchillos metálicos & $-0,77$ & $-0,84$ & $-0,29$ & $-0,27$ & $-0,89$ \\
\hline 83. Manufacturas diversas de metales & 0,46 & 0,60 & 0,70 & 0,50 & 0,53 \\
\hline 84. Máquinas y aparatos mecánicos & $-0,86$ & 0,17 & 0,11 & $-0,12$ & 0,28 \\
\hline 85. Máquinas, aparatos y material eléctricos & 0,77 & 0,97 & 0,99 & 0,92 & 0,94 \\
\hline 86. Vehículos, material ferroviarios & $-0,91$ & $-0,86$ & $-0,99$ & $-1,00$ & $-0,08$ \\
\hline 87. Vehículos automóviles, tractores & $-0,13$ & $-0,22$ & 0,24 & $-0,35$ & $-0,57$ \\
\hline 88. Aeronaves, vehículos espaciales & 1,00 & $-1,00$ & $-0,95$ & - & $-1,00$ \\
\hline 89. Barcos y embarcaciones & - & - & - & $-1,00$ & $-1,00$ \\
\hline 90. Aparatos ópticos, de medida, médicos & $-0,78$ & $-0,72$ & $-0,59$ & $-0,77$ & $-0,74$ \\
\hline 91. Relojería & $-0,09$ & 0,06 & $-0,95$ & $-0,51$ & $-0,10$ \\
\hline 92. Instrumentos musicales & $-1,00$ & $-0,83$ & $-1,00$ & $-1,00$ & $-0,56$ \\
\hline 93. Armas y municiones, accesorios & $-0,40$ & $-0,94$ & $-0,97$ & $-0,25$ & $-0,36$ \\
\hline 94. Muebles, sillas, lámparas & 0,11 & 0,19 & $-0,04$ & $-0,02$ & 0,42 \\
\hline 95. Juguetes, juegos, artículos deportivos & $-0,92$ & $-0,91$ & $-0,05$ & $-0,59$ & $-0,80$ \\
\hline 96. Manufacturas diversas & $-0,48$ & $-0,76$ & $-0,72$ & $-0,95$ & $-0,89$ \\
\hline 97. Objetos de arte, antigüedades & $-1,00$ & $-1,00$ & $-0,68$ & $-1,00$ & $-0,98$ \\
\hline \multicolumn{6}{|l|}{ 98. Conjuntos industriales } \\
\hline 99. Conjuntos de otros productos & $-0,83$ & $-0,14$ & $-0,23$ & $-0,15$ & $-0,48$ \\
\hline
\end{tabular}




\section{J.L. Placer Galán}

León. Índice de contribución al saldo. 2010-2014

\begin{tabular}{|c|c|c|c|c|c|}
\hline Capítulos & 2010 & 2011 & 2012 & 2013 & 2014 \\
\hline 01. Animales vivos & $-1,12$ & $-0,70$ & $-0,46$ & $-0,33$ & $-0,60$ \\
\hline 02. Carne y despojos comestibles & 1,46 & 0,80 & 1,08 & 1,92 & 1,80 \\
\hline 03. Pescados, crustáceos y moluscos & $-4,44$ & $-3,29$ & $-2,25$ & $-2,32$ & $-2,36$ \\
\hline 04. Leche, productos lácteos, huevos & 0,79 & $-0,89$ & 0,18 & 1,90 & 1,48 \\
\hline 05. Otros productos de origen animal & $-0,04$ & $-0,09$ & $-0,08$ & $-0,08$ & $-0,08$ \\
\hline 06. Plantas vivas y productos de floricultura & $-0,07$ & $-0,07$ & $-0,05$ & $-0,05$ & $-0,05$ \\
\hline 07. Legumbres, hortalizas & $-14,25$ & $-11,42$ & $-14,20$ & $-16,21$ & $-12,28$ \\
\hline 08. Frutos comestibles & $-0,29$ & $-0,28$ & $-0,31$ & $-0,30$ & $-0,22$ \\
\hline 09. Café, té, yerba mate y especias & $-0,07$ & $-0,09$ & $-0,13$ & $-0,12$ & $-0,19$ \\
\hline 10. Cereales & $-4,66$ & $-4,90$ & $-5,31$ & $-0,35$ & $-1,82$ \\
\hline 11. Productos de la molinería, malta & 0,00 & $-0,05$ & $-0,54$ & $-0,14$ & $-0,09$ \\
\hline 12. Semillas y frutos oleaginosos & $-1,08$ & $-1,21$ & $-1,42$ & $-1,63$ & $-1,87$ \\
\hline 13. Jugos y extractos vegetales & $-0,03$ & $-0,03$ & $-0,06$ & $-0,05$ & $-0,21$ \\
\hline 14. Materias trenzables & 0,00 & 0,00 & 0,00 & 0,00 & 0,00 \\
\hline 15. Grasas, aceite animal y vegetal & $-0,49$ & $-0,45$ & $-0,11$ & $-0,17$ & $-0,39$ \\
\hline 16. Conservas de carne o pescado & 0,16 & 0,09 & 0,06 & 0,19 & 0,12 \\
\hline 17. Azúcares, artículos de confitería & 0,02 & 0,37 & 0,48 & $-0,38$ & $-1,30$ \\
\hline 18. Cacao y sus preparaciones & 0,00 & $-0,13$ & $-0,03$ & $-0,28$ & $-0,08$ \\
\hline 19. Productos de cereales, de pastelería & 0,09 & $-0,03$ & $-0,26$ & $-0,30$ & $-0,61$ \\
\hline 20. Conservas de verdura o fruta, zumo & $-0,40$ & $-0,50$ & $-0,35$ & $-0,67$ & $-0,68$ \\
\hline 21. Preparaciones alimenticias diversas & 2,48 & 1,40 & 0,82 & 1,08 & 0,89 \\
\hline 22. Bebidas de todo tipo (excluidos zumos) & 0,42 & 0,27 & 0,26 & 0,44 & 0,13 \\
\hline 23. Residuos de la industria alimentaria & $-0,39$ & $-0,56$ & $-0,49$ & $-0,52$ & $-0,23$ \\
\hline 24. Tabaco y sus sucedáneos & 0,00 & 0,00 & 0,00 & 0,00 & 0,00 \\
\hline 25. Sal, yeso piedras sin trabajar & 0,20 & 0,02 & $-0,05$ & 0,01 & 0,11 \\
\hline 26. Minerales, escorias y cenizas & 0,01 & 0,12 & 0,14 & 0,12 & 0,13 \\
\hline 27. Combustibles, aceites minerales & 0,60 & $-3,16$ & $-0,01$ & $-0,62$ & $-0,93$ \\
\hline 28. Productos químicos inorgánicos & $-2,46$ & $-1,57$ & $-0,39$ & $-0,19$ & $-0,16$ \\
\hline 29. Productos químicos orgánicos & 0,16 & $-2,11$ & $-2,57$ & $-2,10$ & $-2,73$ \\
\hline 30. Productos farmacéuticos & 1,45 & 1,98 & 1,95 & 2,96 & 3,66 \\
\hline 31. Abonos & $-1,71$ & $-1,27$ & $-1,57$ & $-1,33$ & $-0,97$ \\
\hline 32. Tanino, materias colorantes, pintura & 0,03 & $-0,77$ & $-0,32$ & $-0,55$ & $-0,52$ \\
\hline 33. Aceites esenciales, preparac. de perfumería & $-0,07$ & $-0,16$ & $-0,08$ & $-0,10$ & $-0,25$ \\
\hline 34. Jabones, lubricantes, ceras & $-0,11$ & $-0,06$ & $-0,02$ & $-0,02$ & $-0,06$ \\
\hline 35. Materias albuminoideas, colas & $-0,24$ & $-0,16$ & $-0,20$ & $-0,20$ & $-0,19$ \\
\hline 36. Pólvoras y explosivos & $-0,14$ & 0,00 & 0,00 & $-0,86$ & $-1,78$ \\
\hline 37. Productos fotográficos o cinematográficos & 0,00 & 0,00 & 0,00 & 0,00 & 0,00 \\
\hline 38. Otros productos químicos & $-0,32$ & $-0,78$ & $-0,28$ & $-0,29$ & $-0,25$ \\
\hline 39. Materias plásticas y sus manufacturas & $-2,67$ & $-3,00$ & $-2,64$ & $-3,79$ & $-3,57$ \\
\hline 40. Caucho y sus manufacturas & $-0,15$ & $-0,56$ & $-0,24$ & $-0,08$ & 0,16 \\
\hline 41. Pieles (excepto la peletería) y cueros & 0,04 & 0,02 & $-0,06$ & $-0,01$ & $-0,01$ \\
\hline 42. Manufacturas de cuero, marroquinería & $-0,29$ & $-0,58$ & $-0,13$ & $-0,68$ & $-0,38$ \\
\hline 43. Peletería y sus confecciones & 0,09 & 0,00 & 0,01 & 0,00 & 0,01 \\
\hline 44. Madera y sus manufacturas & 0,67 & 0,18 & 0,18 & 0,67 & 0,23 \\
\hline 45. Corcho y sus manufacturas & $-0,02$ & $-0,02$ & $-0,06$ & $-0,03$ & $-0,04$ \\
\hline 46. Manufacturas de cestería & 0,00 & $-0,01$ & 0,00 & 0,00 & 0,00 \\
\hline 47. Pasta de madera, papel reciclado & 0,00 & 0,00 & 0,00 & 0,00 & $-0,01$ \\
\hline 48. Papel y cartón, sus manufacturas & $-0,69$ & $-0,62$ & $-0,76$ & $-0,60$ & $-0,98$ \\
\hline 49. Libros, publicaciones, artes gráficas & 0,18 & 0,09 & 0,00 & 0,06 & 0,08 \\
\hline
\end{tabular}


León. Índice de contribución al saldo. 2010-2014. (cont.)

\begin{tabular}{|c|c|c|c|c|c|}
\hline Capítulos & 2010 & 2011 & 2012 & 2013 & 2014 \\
\hline 50. Seda & 0,00 & 0,00 & 0,00 & 0,00 & 0,00 \\
\hline 51. Lana y pelo fino & 0,00 & 0,00 & 0,00 & 0,00 & 0,00 \\
\hline 52. Algodón & $-0,01$ & $-0,01$ & $-0,01$ & $-0,06$ & $-0,04$ \\
\hline 53. Otras fibras textiles vegetales & 0,00 & 0,00 & 0,00 & 0,00 & 0,00 \\
\hline 54. Filamentos sintéticos o artificiales & $-0,01$ & $-0,01$ & $-0,01$ & $-0,01$ & $-0,02$ \\
\hline 55. Fibras sintéticas o artificiales discontinuas & $-0,03$ & $-0,04$ & $-0,03$ & $-0,05$ & $-0,03$ \\
\hline 56. Fieltro, tela sin tejer, cordelería & $-0,03$ & $-0,02$ & $-0,03$ & $-0,01$ & $-0,01$ \\
\hline 57. Alfombras y revestimientos textiles para el suelo & $-0,05$ & $-0,01$ & $-0,01$ & $-0,01$ & $-0,01$ \\
\hline 58. Tejidos especiales, tapicería, bordados & 0,00 & 0,00 & 0,00 & 0,00 & 0,00 \\
\hline 59. Tejidos recubiertos, técnicos de materias textiles & $-0,02$ & $-0,01$ & $-0,04$ & $-0,02$ & $-0,01$ \\
\hline 60. Tejidos de punto & 0,00 & $-0,01$ & $-0,01$ & 0,00 & 0,00 \\
\hline 61. Prendas de vestir de punto & $-0,71$ & $-0,60$ & $-0,56$ & $-0,43$ & $-0,55$ \\
\hline 62. Prendas de vestir, excepto las de punto & $-1,01$ & $-1,13$ & $-0,88$ & $-0,86$ & $-1,00$ \\
\hline 63. Demás artículos textiles, prendería & $-0,12$ & $-0,03$ & $-0,03$ & $-0,04$ & $-0,03$ \\
\hline 64. Calzado y sus partes & $-0,45$ & $-0,32$ & $-0,22$ & $-0,20$ & $-0,24$ \\
\hline 65. Artículos de sombrerería & $-0,02$ & $-0,02$ & $-0,01$ & $-0,01$ & $-0,01$ \\
\hline 66. Paraguas, sombrillas, bastones & 0,00 & 0,00 & 0,00 & 0,00 & 0,00 \\
\hline 67. Plumas y plumón preparados & $-0,01$ & $-0,01$ & $-0,01$ & $-0,01$ & $-0,01$ \\
\hline 68. Manufacturas de piedra, yeso & 7,25 & 4,11 & 2,39 & 3,26 & 3,33 \\
\hline 69. Productos cerámicos & $-0,53$ & $-0,42$ & $-0,25$ & $-0,36$ & $-0,41$ \\
\hline 70. Vidrio y sus manufacturas & 0,75 & $-0,70$ & $-0,26$ & 0,01 & $-0,17$ \\
\hline 71. Piedras y metales preciosos, bisutería & $-0,10$ & $-0,09$ & $-0,07$ & $-0,07$ & $-0,08$ \\
\hline 72. Fundición, hierro y acero & 22,32 & 6,38 & 7,98 & 8,87 & 10,07 \\
\hline 73. Manufacturas de fundición, hierro y acero & 1,16 & $-0,27$ & $-0,22$ & $-0,98$ & 1,63 \\
\hline 74. Cobre y sus manufacturas & $-0,83$ & $-1,97$ & $-3,57$ & $-2,74$ & $-2,73$ \\
\hline 75. Níquel y sus manufacturas & 0,00 & 0,00 & 0,00 & 0,00 & 0,00 \\
\hline 76. Aluminio y sus manufacturas & $-0,48$ & $-0,46$ & $-0,50$ & $-0,76$ & $-0,86$ \\
\hline 78. Plomo y sus manufacturas & $-0,01$ & 0,00 & 0,00 & 0,00 & 0,00 \\
\hline 79. Cinc y sus manufacturas & $-0,01$ & 0,01 & $-0,02$ & $-0,04$ & $-0,05$ \\
\hline 80. Estaño y sus manufacturas & 0,00 & 0,00 & 0,00 & 0,00 & $-0,09$ \\
\hline 81. Demás metales comunes, cermets & $-0,02$ & $-0,03$ & $-0,01$ & 0,00 & 0,00 \\
\hline 82. Herramientas y cuchillos metálicos & $-0,19$ & $-0,20$ & $-0,11$ & $-0,08$ & $-0,17$ \\
\hline 83. Manufacturas diversas de metales & 0,02 & 0,01 & 0,01 & 0,00 & 0,00 \\
\hline 84. Máquinas y aparatos mecánicos & $-14,89$ & $-2,37$ & $-2,41$ & $-3,41$ & $-2,38$ \\
\hline 85. Máquinas, aparatos y material eléctricos & 20,38 & 37,01 & 32,78 & 28,22 & 25,78 \\
\hline 86. Vehículos, material ferroviarios & $-0,09$ & $-0,11$ & $-0,07$ & $-0,05$ & $-0,03$ \\
\hline 87. Vehículos automóviles, tractores & $-1,47$ & $-1,56$ & $-0,74$ & $-1,62$ & $-2,45$ \\
\hline 88. Aeronaves, vehículos espaciales & 0,00 & 0,00 & $-0,01$ & 0,00 & 0,00 \\
\hline 89. Barcos y embarcaciones & 0,00 & 0,00 & 0,00 & 0,00 & 0,00 \\
\hline 90. Aparatos ópticos, de medida, médicos & $-0,75$ & $-0,66$ & $-0,74$ & $-0,89$ & $-1,03$ \\
\hline 91. Relojería & $-0,04$ & $-0,04$ & $-0,07$ & $-0,10$ & $-0,05$ \\
\hline 92. Instrumentos musicales & 0,00 & 0,00 & 0,00 & $-0,24$ & 0,00 \\
\hline 93. Armas y municiones, accesorios & $-1,13$ & $-0,94$ & $-0,86$ & $-1,02$ & $-1,01$ \\
\hline 94. Muebles, sillas, lámparas & $-0,19$ & $-0,15$ & $-0,17$ & $-0,15$ & $-0,05$ \\
\hline 95. Juguetes, juegos, artículos deportivos & $-0,05$ & $-0,05$ & $-0,02$ & $-0,04$ & $-0,04$ \\
\hline 96. Manufacturas diversas & $-0,04$ & $-0,06$ & $-0,05$ & $-0,05$ & $-0,06$ \\
\hline 97. Objetos de arte, antigüedades & 0,00 & 0,00 & 0,00 & 0,00 & 0,00 \\
\hline 98. Conjuntos industriales & 0,00 & 0,00 & 0,00 & 0,00 & 0,00 \\
\hline 99. Conjuntos de otros productos & $-1,19$ & $-1,00$ & $-0,87$ & $-0,05$ & $-0,10$ \\
\hline
\end{tabular}


León. Exportaciones por áreas geográficas y países (en miles de euros)

\begin{tabular}{|c|c|c|c|c|c|}
\hline Área geográfica/País & 2010 & 2011 & 2012 & 2013 & 2014 \\
\hline ZONA EURO & $694.893,72$ & $815.009,26$ & $979.041,99$ & $726.974,85$ & $820.434,44$ \\
\hline 001.Francia & $241.260,24$ & $216.240,97$ & $256.108,03$ & $203.867,22$ & $265.279,16$ \\
\hline 003. Países Bajos & $24.555,00$ & $27.387,78$ & $38.022,00$ & $37.655,46$ & $59.763,94$ \\
\hline 004. Alemania & $133.872,78$ & $262.913,35$ & $260.456,70$ & $183.799,69$ & $191.378,10$ \\
\hline 005. Italia & $164.595,20$ & $150.280,87$ & $252.840,77$ & $154.485,07$ & $169.331,72$ \\
\hline 007. Irlanda & $18.313,78$ & $3.153,88$ & $15.479,72$ & $9.201,23$ & 938,74 \\
\hline 009. Grecia & $4.239,39$ & $9.584,78$ & $5.076,62$ & $4.285,11$ & $14.633,54$ \\
\hline 010. Portugal & $87.414,71$ & $98.110,93$ & $107.294,90$ & $100.344,93$ & $94.583,19$ \\
\hline 017. Bélgica & $11.459,45$ & $18.275,98$ & $26.290,01$ & $20.542,20$ & $13.855,12$ \\
\hline 018.Luxemburgo & 92,71 & 14,84 & 81,72 & 778,69 & 316,32 \\
\hline 032. Finlandia & $4.892,93$ & $3.013,21$ & $3.917,69$ & $4.201,18$ & $4.132,59$ \\
\hline 038. Austria & $3.831,09$ & $24.588,65$ & $7.745,28$ & $7.107,66$ & $3.942,85$ \\
\hline 046. Malta & 23,34 & 5,10 & 45,41 & 8,44 & 964,32 \\
\hline 053. Estonia & 5,11 & 6,09 & 135,60 & 78,95 & 7,17 \\
\hline 054. Letonia & 6,50 & 57,38 & 16,25 & 7,50 & 4,17 \\
\hline 063. Eslovaquia & 22,28 & $1.274,62$ & 399,83 & 537,68 & 768,71 \\
\hline 091. Eslovenia & 76,50 & 21,98 & 21,54 & 19,30 & 403,35 \\
\hline 600. Chipre & 232,71 & 78,85 & $5.109,92$ & 54,53 & 131,45 \\
\hline RESTO UE & $64.233,07$ & $300.894,33$ & $384.925,58$ & $299.740,26$ & $271.655,21$ \\
\hline 006. Reino Unido & $40.828,70$ & $79.487,68$ & $126.103,14$ & $95.090,70$ & $88.997,39$ \\
\hline 008. Dinamarca & $4.915,65$ & $20.801,28$ & $9.498,88$ & $20.033,14$ & $14.854,72$ \\
\hline 030. Suecia & $10.219,65$ & $93.486,73$ & $109.668,38$ & $33.856,60$ & $74.079,19$ \\
\hline 055. Lituania & 219,81 & 680,69 & 288,26 & 304,18 & 457,92 \\
\hline 060. Polonia & $4.603,81$ & $62.306,25$ & $87.122,02$ & $110.258,11$ & $70.630,05$ \\
\hline 061. República Checa & $1.048,77$ & $5.694,71$ & $11.651,99$ & $7.844,25$ & $8.104,69$ \\
\hline 064. Hungría & $1.869,49$ & $1.914,86$ & $1.165,46$ & $2.064,15$ & $1.393,10$ \\
\hline 066. Rumania & 408,77 & $36.012,18$ & $36.361,62$ & $30.189,34$ & $6.120,22$ \\
\hline 068. Bulgaria & 47,43 & 474,45 & $2.973,00$ & 66,61 & 106,20 \\
\hline 092. Croacia & 70,95 & 35,51 & 92,84 & 33,18 & $6.911,73$ \\
\hline RESTO EUROPA & $7.086,51$ & $22.891,20$ & $16.022,11$ & $18.475,48$ & $15.108,60$ \\
\hline 024. Islandia & 0,22 & 0,00 & 0,00 & 12,67 & 1,87 \\
\hline 028. Noruega & 85,51 & 480,10 & 550,35 & 195,98 & 471,99 \\
\hline 037. Liechtenstein & & & & & 0,88 \\
\hline 039. Suiza & $4.636,00$ & $6.165,60$ & $7.894,24$ & $8.755,93$ & $5.542,44$ \\
\hline \multicolumn{6}{|l|}{041 Islas Feroe } \\
\hline 043. Andorra & 771,97 & 498,87 & 547,91 & 417,63 & 534,89 \\
\hline 044. Gibraltar & 16,43 & 251,58 & 47,93 & 16,52 & 11,00 \\
\hline 052. Turquía & 391,57 & $13.776,19$ & $5.227,03$ & $6.414,51$ & $3.542,93$ \\
\hline 070. Albania & 62,63 & 63,26 & 115,99 & 71,57 & 45,52 \\
\hline 072. Ucrania & 110,87 & 207,07 & 182,57 & 339,78 & 146,27 \\
\hline 073. Bielorrusia & 331,50 & & 132,48 & 91,95 & 405,75 \\
\hline 074. Moldavia & 0,26 & & 3,20 & & \\
\hline 075. Rusia & 573,19 & $1.334,22$ & $1.140,05$ & $2.082,13$ & $4.306,25$ \\
\hline 093. Bosnia-Herzegovina & & & & 1,53 & 58,91 \\
\hline 095. Kosovo & & & 5,29 & & \\
\hline 096. Macedonia & & & & 5,18 & 2,64 \\
\hline 097. Montenegro & & 0,17 & 46,02 & 2,82 & \\
\hline 098. Serbia & 106,36 & 114,15 & 129,06 & 67,27 & 37,26 \\
\hline
\end{tabular}


León. Exportaciones por áeas geográficas y países (cont.)

\begin{tabular}{|c|c|c|c|c|c|}
\hline Área geográfica/País & 2010 & 2011 & 2012 & 2013 & 2014 \\
\hline AMÉRICA DEL NORTE & $9.038,51$ & $27.406,12$ & $32.244,96$ & $21.686,98$ & $26.330,50$ \\
\hline 400. EEUU & $7.608,72$ & $21.416,13$ & $30.090,00$ & $19.173,91$ & $21.720,44$ \\
\hline 404. Canadá & $1.429,79$ & $5.989,99$ & $2.154,97$ & $2.513,08$ & $4.610,06$ \\
\hline IBEROAMÉRICA & $37.502,27$ & $56.154,93$ & $64.904,77$ & $81.608,63$ & $46.686,51$ \\
\hline 412. México & $5.653,57$ & $3.664,06$ & $12.887,60$ & $5.370,23$ & $8.882,22$ \\
\hline 416. Guatemala & 20,88 & 116,87 & 454,26 & 560,36 & 286,49 \\
\hline 424. Honduras & 14,97 & 37,41 & 27,15 & 55,28 & 8,88 \\
\hline 428. El Salvador & 179,75 & 75,88 & 125,69 & 109,45 & 35,60 \\
\hline 432. Nicaragua & 4,73 & 15,34 & 32,00 & 132,01 & 51,31 \\
\hline 436. Costa Rica & 426,03 & 728,92 & 951,63 & 331,83 & 468,78 \\
\hline 442. Panamá & $2.735,32$ & $5.761,31$ & $7.327,41$ & $6.817,89$ & $5.517,33$ \\
\hline 448. Cuba & 748,82 & 821,37 & $1.106,34$ & $1.208,67$ & 632,89 \\
\hline 456. República Dominicana & $14.496,87$ & 704,25 & 507,45 & 438,68 & 375,75 \\
\hline 480. Colombia & 163,40 & 553,55 & 689,36 & $1.081,34$ & 798,21 \\
\hline 484. Venezuela & 666,97 & $1.301,37$ & $1.505,90$ & $1.059,98$ & 787,07 \\
\hline 500. Ecuador & 323,60 & 149,94 & 172,23 & 170,68 & 198,55 \\
\hline 504. Perú & 415,63 & $2.345,41$ & $6.876,90$ & $9.913,13$ & $5.797,10$ \\
\hline 508. Brasil & 789,99 & $21.358,06$ & $7.149,32$ & $3.840,29$ & $5.768,11$ \\
\hline 512. Chile & $6.586,36$ & $13.152,62$ & $17.340,44$ & $45.517,82$ & $14.717,44$ \\
\hline 516. Bolivia & 50,59 & 39,56 & 93,35 & 164,79 & 56,04 \\
\hline 520. Paraguay & 2,66 & 74,52 & 213,83 & 672,65 & 252,94 \\
\hline 524. Uruguay & 46,95 & 45,84 & $2.237,16$ & $1.057,23$ & 97,80 \\
\hline 528. Argentina & $4.175,19$ & $5.208,64$ & $5.206,76$ & $3.106,32$ & $1.954,01$ \\
\hline RESTO DE AMÉRICA & $6.863,39$ & 27,86 & 72,52 & 25,00 & 69,53 \\
\hline 413. Bermudas & 5,04 & 1,64 & 7,26 & & \\
\hline 421. Belice & & & & & 51,03 \\
\hline 452. Haití & & & & & 0,01 \\
\hline 453. Bahamas & & & & 6,84 & \\
\hline 454. Islas Turcas y Caicos & & & & 1,84 & \\
\hline 463. Islas Caimán & & 1,43 & 0,00 & & \\
\hline 464. Jamaica & $6.844,50$ & & & & \\
\hline 468. Islas Vírgenes (GB) & & & 56,32 & & \\
\hline 469. Barbados & & 0,60 & & & \\
\hline 475. Curaçao & & & & 7,77 & 9,71 \\
\hline 478. Antillas Neerlandesas & 13,85 & 18,99 & 8,94 & & \\
\hline 529. Islas Malvinas & & 5,20 & & 8,56 & 8,78 \\
\hline ASIA & $47.977,76$ & $37.747,01$ & $42.024,68$ & $29.302,10$ & $44.860,36$ \\
\hline 076. Georgia & & 290,00 & 54,76 & 79,25 & 20,33 \\
\hline 077. Armenia & & 0,53 & 1,00 & 7,24 & \\
\hline 078. Azerbaiyán & & 94,44 & & 27,61 & 33,41 \\
\hline 079. Kazajstán & 10,99 & 0,02 & 12,59 & 16,79 & 2,24 \\
\hline 081 Uzbekistán & 8,09 & & & & 5,25 \\
\hline 604. Líbano & 71,15 & 181,45 & 74,79 & 81,89 & 130,29 \\
\hline 608. Siria & 387,41 & 153,51 & 107,73 & & 54,93 \\
\hline 612. Irak & 485,34 & 318,74 & 441,73 & 895,01 & 678,48 \\
\hline 616. Irán & 404,33 & 625,37 & 599,56 & 243,36 & $1.283,51$ \\
\hline 624. Israel & $1.047,84$ & $2.068,76$ & $1.871,52$ & $1.682,41$ & $2.308,67$ \\
\hline 625. Cisjordania/Franja de Gaza & & & & 0,40 & \\
\hline 628. Jordania & 156,34 & 184,29 & 158,38 & 371,80 & 211,76 \\
\hline
\end{tabular}


León. Exportaciones por áreas geográficas y países (cont.)

\begin{tabular}{|c|c|c|c|c|c|}
\hline Área geográfica/País & 2010 & 2011 & 2012 & 2013 & 2014 \\
\hline \multicolumn{6}{|l|}{ ASIA (cont.) } \\
\hline 632. Arabia Saudí & $2.982,19$ & $3.008,47$ & $2.297,05$ & $3.708,79$ & $2.523,17$ \\
\hline 636. Kuwait & 95,82 & 203,81 & 82,37 & 516,28 & 209,30 \\
\hline 640. Bahrein & & 159,46 & 206,01 & 2,24 & 8,35 \\
\hline 644. Qatar & 9,39 & 121,11 & 60,68 & 148,32 & 45,46 \\
\hline 647. Emiratos Árabes Unidos & 298,99 & 512,07 & 271,50 & $2.454,67$ & $1.527,78$ \\
\hline 649. Omán & 124,40 & 18,49 & 71,54 & 30,43 & $13.949,64$ \\
\hline 653. Yemen & & & 0,01 & 35,53 & 9,52 \\
\hline 660. Afganistán & 94,20 & 31,19 & 297,06 & 74,08 & 293,77 \\
\hline 662. Pakistán & 411,00 & 466,20 & $12.651,83$ & 446,75 & 317,10 \\
\hline 664. India & $5.204,66$ & $5.839,35$ & $1.608,70$ & 140,04 & 203,89 \\
\hline 666. Bangladesh & 284,49 & 127,66 & 0,02 & 0,01 & 47,86 \\
\hline 667. Islas Maldivas & & 9,51 & 2,79 & & 4,50 \\
\hline 669. Sri Lanka & 23,72 & 67,43 & 97,05 & 281,04 & 75,52 \\
\hline 672. Nepal & & 2,96 & & 2,23 & \\
\hline 680. Tailandia & $1.645,50$ & $1.940,23$ & $2.332,70$ & $2.986,74$ & $2.386,95$ \\
\hline 690. Vietnam & 550,05 & 338,72 & $1.155,93$ & 721,21 & 958,25 \\
\hline 696. Camboya (Kampuchea) & 0,96 & & & & 383,75 \\
\hline 700. Indonesia & 971,22 & 617,42 & 799,26 & 367,03 & 51,53 \\
\hline 701. Malasia & 58,82 & 64,39 & 102,81 & 299,15 & 128,07 \\
\hline 706. Singapur & 374,29 & 268,97 & 72,89 & 195,37 & 58,89 \\
\hline 708. Filipinas & 31,86 & 100,30 & 332,53 & 374,22 & 258,77 \\
\hline 716. Mongolia & & & 131,56 & 112,48 & \\
\hline 720. China & $9.415,95$ & $6.853,72$ & $9.288,69$ & $4.777,43$ & $1.330,58$ \\
\hline 728. Corea del Sur & $3.484,56$ & $1.131,46$ & $1.392,39$ & $1.079,39$ & $2.599,81$ \\
\hline 732. Japón & $10.516,18$ & $2.463,74$ & $1.417,00$ & $1.127,35$ & $3.108,14$ \\
\hline 736. Taiwán & $6.531,93$ & $8.033,02$ & 479,14 & 325,04 & 364,79 \\
\hline 740. Hong-Kong & $2.296,10$ & $1.450,21$ & $3.551,10$ & $5.689,75$ & $9.275,73$ \\
\hline 743. Macao & & & & 0,78 & 10,38 \\
\hline ÁFRICA & $10.007,04$ & $10.598,30$ & $11.382,69$ & $10.131,63$ & $12.273,29$ \\
\hline 204. Marruecos & $2.010,00$ & $2.243,54$ & $1.785,43$ & $1.554,39$ & $3.063,07$ \\
\hline 208. Argelia & 863,72 & $1.547,86$ & $1.881,69$ & $1.998,67$ & $1.610,63$ \\
\hline 212. Túnez & 442,51 & 132,09 & 142,34 & 102,00 & 573,07 \\
\hline 216. Libia & $1.370,29$ & 599,15 & $1.735,25$ & $2.422,97$ & $1.565,23$ \\
\hline 220. Egipto & 310,92 & 196,04 & 167,92 & 205,47 & 328,84 \\
\hline 228. Mauritania & & $1.381,18$ & 369,98 & 318,05 & 512,50 \\
\hline 232. Mali & 962,27 & 35,93 & $2.171,09$ & 10,64 & 178,38 \\
\hline 236. Burkina Faso & & & 0,01 & 5,00 & 6,30 \\
\hline 240. Níger & 9,90 & & & 11,75 & 9,14 \\
\hline 247. Cabo Verde & 0,46 & & & & \\
\hline 248. Senegal & 81,67 & 112,64 & 105,65 & 917,61 & $1.300,19$ \\
\hline 252. Gambia & 13,30 & & & & 0,50 \\
\hline 257. Guinea Bissau & 981,88 & 469,17 & 248,93 & 305,39 & \\
\hline 260. Guinea & 7,00 & 13,82 & 19,37 & 43,85 & 5,15 \\
\hline 264. Sierra Leona & & & 752,63 & 127,40 & 345,00 \\
\hline 268. Liberia & & & & & 60,17 \\
\hline 272. Costa de Marfil & 4,65 & 44,25 & 58,60 & 32,14 & 44,52 \\
\hline 276. Ghana & 268,66 & $1.637,02$ & 423,54 & 773,89 & 711,97 \\
\hline 280. Togo & 28,54 & 96,59 & 62,70 & 10,48 & 41,16 \\
\hline
\end{tabular}


León. Exportaciones por áreas geográficas y países (cont.)

\begin{tabular}{|c|c|c|c|c|c|}
\hline Área geográfica/País & 2010 & 2011 & 2012 & 2013 & 2014 \\
\hline \multicolumn{6}{|l|}{ ÁFRICA (cont.) } \\
\hline 284. Benin & 0,63 & 47,21 & 0,01 & & \\
\hline 288. Nigeria & 48,22 & 5,29 & 21,60 & 24,56 & 71,38 \\
\hline 302. Camerún & 110,68 & 516,25 & 341,34 & 458,28 & 237,96 \\
\hline 306. República Centroafricana & & 85,31 & & & \\
\hline 310. Guinea Ecuatorial & 17,97 & 259,66 & 226,78 & 302,06 & 554,22 \\
\hline 314. Gabón & & & 60,48 & & 398,38 \\
\hline 318. Congo & 306,75 & 130,50 & 58,70 & 140,99 & 133,01 \\
\hline 322. Rep. Democrática del Congo & 733,81 & 98,55 & 44,95 & 7,05 & 21,37 \\
\hline 330. Angola & 775,89 & 777,75 & 635,57 & 233,83 & 189,21 \\
\hline 334. Etiopía & & & 8,45 & 2,50 & 0,03 \\
\hline 346. Kenia & & & & 1,36 & 13,88 \\
\hline 350. Uganda & 6,28 & & & & \\
\hline 352. Tanzania & & & & 17,00 & \\
\hline 355. Seychelles & & 0,00 & & & \\
\hline 366. Mozambique & 9,27 & 13,49 & 7,06 & 18,61 & 41,78 \\
\hline 370. Madagascar & & & & & 36,55 \\
\hline 373. Mauricio & & & & & 197,14 \\
\hline 378. Zambia & & & 0,00 & & \\
\hline 382. Zimbabwe & 84,69 & 16,48 & & 1,99 & \\
\hline 388. Sudáfrica & 557,08 & 138,51 & 51,82 & 81,80 & 20,29 \\
\hline 389. Namibia & & & & 1,91 & 1,17 \\
\hline 395. Lesotho & & & 0,80 & & 1,10 \\
\hline OCEANÍA & $1.017,52$ & $6.816,95$ & 536,02 & 290,04 & $1.447,95$ \\
\hline 800. Australia & 998,35 & $6.800,82$ & 475,17 & 258,53 & $1.238,28$ \\
\hline 804. Nueva Zelanda & 19,17 & 16,13 & 29,02 & 31,51 & 209,68 \\
\hline 809. Nueva Caledonia y dependencias & & & 31,84 & & \\
\hline SIN DETERMINAR & 1,04 & 23,55 & 47,61 & 123,49 & 125,38 \\
\hline $\begin{array}{l}\text { 951. Avituall. y combust. intercambios } \\
\text { comunitarios }\end{array}$ & 1,04 & 7,77 & 1,65 & 98,50 & 42,40 \\
\hline 952. Avituallamiento terceros & & & 4,77 & & 54,57 \\
\hline $\begin{array}{l}\text { 960. Países y territorios no determinados. } \\
\text { Extracomunitarios. }\end{array}$ & & 15,78 & 41,19 & 24,99 & 28,41 \\
\hline MUNDO & $878.620,83$ & $1.277 .569,52$ & $1.531 .202,95$ & $1.188 .358,47$ & $1.238 .991,77$ \\
\hline
\end{tabular}


León. Importaciones por áreas geográficas y países (en miles de euros)

\begin{tabular}{|c|c|c|c|c|c|}
\hline Área geográfica/País & 2010 & 2011 & 2012 & 2013 & 2014 \\
\hline ZONA EURO & $202.734,59$ & $227.418,79$ & $199.059,56$ & $168.126,84$ & $211.108,60$ \\
\hline 001.Francia & $42.417,98$ & $55.783,02$ & $40.028,38$ & $34.484,18$ & $50.367,84$ \\
\hline 003. Países Bajos & $17.399,35$ & $19.391,47$ & $13.171,30$ & $10.333,96$ & $21.602,84$ \\
\hline 004. Alemania & $60.557,93$ & $55.296,20$ & $36.032,01$ & $34.215,46$ & $43.653,44$ \\
\hline 005. Italia & $32.142,53$ & $44.399,90$ & $41.902,23$ & $32.439,15$ & $32.607,47$ \\
\hline 007. Irlanda & 506,93 & 524,61 & 507,87 & 663,27 & 519,42 \\
\hline 009. Grecia & 507,47 & 490,61 & 52,29 & 30,51 & 5,65 \\
\hline 010. Portugal & $26.675,16$ & $24.035,70$ & $33.308,78$ & $27.551,26$ & $27.755,72$ \\
\hline 017. Bélgica & $18.013,01$ & $22.113,11$ & $28.837,83$ & $22.485,79$ & $24.244,25$ \\
\hline 018.Luxemburgo & 727,60 & 448,85 & 874,36 & 681,13 & $2.043,34$ \\
\hline 032. Finlandia & 452,25 & 242,57 & 408,50 & 683,66 & $3.386,31$ \\
\hline 038. Austria & $3.044,22$ & $3.537,90$ & $3.484,39$ & $4.168,06$ & $4.350,60$ \\
\hline 046. Malta & 47,75 & 763,57 & 46,99 & 37,29 & 34,02 \\
\hline 053. Estonia & 4,12 & 11,70 & 13,68 & 4,05 & 16,97 \\
\hline 054. Letonia & 45,69 & 12,14 & & 5,26 & 19,79 \\
\hline 063. Eslovaquia & 152,08 & 315,32 & 383,01 & 332,44 & 461,63 \\
\hline 091. Eslovenia & 7,55 & 0,97 & 0,65 & 1,73 & 32,94 \\
\hline 600. Chipre & 32,97 & 51,15 & 7,31 & 9,66 & 6,39 \\
\hline RESTO UE & $32.342,88$ & $38.215,42$ & $31.527,42$ & $36.354,33$ & $37.529,20$ \\
\hline 006. Reino Unido & $16.542,49$ & $14.598,66$ & $9.369,05$ & $5.985,60$ & $6.501,38$ \\
\hline 008. Dinamarca & $3.774,65$ & $7.125,77$ & $5.065,16$ & $11.195,51$ & $6.156,01$ \\
\hline 030. Suecia & $5.732,38$ & $4.468,39$ & $2.851,37$ & $4.646,93$ & $4.575,59$ \\
\hline 055. Lituania & 518,47 & $7.530,49$ & $6.217,57$ & $4.839,65$ & $6.315,33$ \\
\hline 060. Polonia & $1.474,76$ & $1.997,16$ & $3.858,68$ & $6.792,45$ & $9.692,74$ \\
\hline 061. República Checa & 506,61 & 301,66 & 404,86 & 297,62 & 401,90 \\
\hline 064. Hungría & 420,54 & 285,88 & 874,40 & 758,61 & 444,02 \\
\hline 066. Rumania & 21,33 & 83,83 & 101,79 & 97,08 & 652,62 \\
\hline 068. Bulgaria & $1.773,06$ & $1.805,00$ & $2.784,22$ & $1.738,67$ & $2.568,83$ \\
\hline 092. Croacia & $1.578,58$ & 18,58 & 0,33 & 2,20 & 220,79 \\
\hline RESTO EUROPA & $13.551,62$ & $25.896,58$ & $33.163,69$ & $14.466,96$ & $11.340,22$ \\
\hline 024. Islandia & 156,56 & & 36,75 & & \\
\hline 028. Noruega & $8.827,19$ & $7.540,01$ & $8.419,60$ & $7.621,09$ & $6.222,49$ \\
\hline 037. Liechtenstein & 8,45 & 7,62 & & & \\
\hline 039. Suiza & $1.459,48$ & 951,68 & $1.262,02$ & $1.317,42$ & $1.211,43$ \\
\hline 043. Andorra & 3,26 & 112,38 & 2,35 & 1,25 & 1,37 \\
\hline 052. Turquía & $1.734,69$ & $2.409,57$ & $1.650,61$ & $1.820,31$ & $2.468,19$ \\
\hline 070. Albania & & 29,16 & 10,11 & 15,02 & 50,83 \\
\hline 072. Ucrania & 3,84 & 0,59 & $11.489,50$ & $1.159,42$ & $1.097,81$ \\
\hline 073. Bielorrusia & 0,45 & & & 0,01 & 0,60 \\
\hline 074. Moldavia & 3,99 & 6,59 & 14,52 & 0,19 & 6,85 \\
\hline 075. Rusia & $1.234,28$ & $14.769,86$ & $10.147,81$ & $2.468,37$ & 200,10 \\
\hline 093. Bosnia-Herzegovina & 1,23 & 1,23 & 0,71 & 2,02 & 7,78 \\
\hline 096. Macedonia & 47,20 & & 77,18 & 31,64 & 38,64 \\
\hline 098. Serbia & 70,99 & 67,91 & 52,53 & 30,21 & 34,14 \\
\hline AMÉRICA DEL NORTE & $38.973,80$ & $42.218,25$ & $33.288,16$ & $43.149,81$ & $32.112,94$ \\
\hline 400. EEUU & $24.738,53$ & $32.206,03$ & $23.797,66$ & $29.364,41$ & $21.677,85$ \\
\hline 404. Canadá & $14.235,27$ & $10.012,21$ & $9.490,50$ & $13.785,41$ & $10.435,09$ \\
\hline
\end{tabular}


León. Importaciones por áreas geográficas y países (cont.)

\begin{tabular}{|c|c|c|c|c|c|}
\hline Área geográfica/País & 2010 & 2011 & 2012 & 2013 & 2014 \\
\hline IBEROAMÉRICA & $43.876,42$ & $34.133,56$ & $57.063,07$ & $42.046,23$ & $36.539,48$ \\
\hline 412. México & $20.527,01$ & $12.566,32$ & $23.930,96$ & $24.086,19$ & $15.876,33$ \\
\hline 416. Guatemala & 1,39 & 0,87 & 0,18 & 0,29 & 1,36 \\
\hline 424. Honduras & 0,22 & 0,40 & 0,08 & 0,20 & 0,16 \\
\hline 428. El Salvador & 0,59 & 7,40 & 0,23 & 0,83 & 0,42 \\
\hline 432. Nicaragua & 109,71 & & & 0,11 & 0,02 \\
\hline 436. Costa Rica & & 16,92 & & 0,12 & 0,19 \\
\hline 442. Panamá & & 0,13 & 170,70 & 1,23 & 4,87 \\
\hline 448. Cuba & 32,84 & & 7,03 & & \\
\hline 456. República Dominicana & 5,08 & 1,05 & 0,98 & 3,09 & 1,91 \\
\hline 480. Colombia & 13,06 & 13,39 & 3,00 & 91,86 & 61,72 \\
\hline 484. Venezuela & 12,42 & 8,70 & 8,32 & 25,02 & 1,14 \\
\hline 500. Ecuador & 84,83 & 83,47 & 75,60 & 51,81 & 127,76 \\
\hline 504. Perú & 983,35 & $1.316,69$ & $1.538,58$ & $1.443,26$ & 460,76 \\
\hline 508. Brasil & 265,39 & 180,52 & 369,16 & $2.735,54$ & 982,19 \\
\hline 512. Chile & 943,48 & $1.185,95$ & $1.176,77$ & 657,20 & $1.349,83$ \\
\hline 516. Bolivia & 575,21 & 964,52 & $1.546,34$ & 656,64 & 175,59 \\
\hline 520. Paraguay & 869,55 & $1.041,19$ & 882,49 & $1.154,65$ & $2.206,89$ \\
\hline 524. Uruguay & 102,13 & 99,18 & 354,35 & 0,93 & \\
\hline 528. Argentina & $19.350,16$ & $16.646,85$ & $26.998,29$ & $11.137,25$ & $15.288,34$ \\
\hline RESTO DE AMÉRICA & 34,26 & 69,43 & 0,68 & 1,66 & 153,08 \\
\hline 421. Belice & 34,26 & & & & 106,43 \\
\hline 452. Haití & & 69,43 & & 1,66 & 46,37 \\
\hline 457. Islas Vírgenes (EEUU) & & & & & 0,17 \\
\hline 468. Islas Vírgenes (GB) & & & & & 0,12 \\
\hline 470. Montserrat & & & 0,68 & & \\
\hline ASIA & $104.742,76$ & $42.600,63$ & $31.658,99$ & $55.492,67$ & $51.892,59$ \\
\hline 076. Georgia & 0,09 & & & 1,16 & 0,68 \\
\hline 077. Armenia & & & & & 0,60 \\
\hline 078. Azerbaiyán & & & 94,04 & 26,29 & \\
\hline 081 Uzbekistán & 93,37 & 152,13 & 231,16 & 694,68 & 815,87 \\
\hline 083. Kirguizistán & & & & 110,62 & 7,03 \\
\hline 604. Líbano & 0,22 & & 28,17 & 3,71 & 1,71 \\
\hline 608. Siria & 123,23 & 28,94 & 57,98 & 39,88 & 30,27 \\
\hline 616. Irán & 60,74 & 78,26 & 298,49 & 32,68 & 21,15 \\
\hline 624. Israel & 101,06 & 606,23 & 35,58 & 161,48 & 458,54 \\
\hline 628. Jordania & 2,95 & 0,32 & 1,60 & 0,29 & \\
\hline 632. Arabia Saudí & 2,92 & 0,52 & & & \\
\hline 640. Bahrein & & & 0,24 & & \\
\hline 647. Emiratos Árabes Unidos & 49,07 & 25,85 & 5,54 & 48,59 & 27,46 \\
\hline 660. Afganistán & 0,49 & 54,76 & 474,67 & 611,88 & 452,53 \\
\hline 662. Pakistán & 84,81 & 46,70 & 35,15 & 174,86 & 90,36 \\
\hline 664. India & $2.986,14$ & $5.062,99$ & $2.886,27$ & $3.948,80$ & $4.875,11$ \\
\hline 666. Bangladesh & 141,37 & 154,70 & 133,41 & 246,03 & 285,20 \\
\hline 669. Sri Lanka & 90,16 & 42,18 & 74,21 & 22,47 & 321,68 \\
\hline 676. Myanmar & 39,19 & 54,37 & 39,52 & 17,93 & 66,06 \\
\hline 680. Tailandia & 616,90 & 505,37 & 314,32 & 443,48 & 440,23 \\
\hline 684. Laos & 0,76 & 2,51 & 0,80 & 0,05 & 0,07 \\
\hline
\end{tabular}




\section{J.L. Placer Galán}

León. Importaciones por áreas geográficas y países (cont.)

\begin{tabular}{|c|c|c|c|c|c|}
\hline Área geográfica/País & 2010 & 2011 & 2012 & 2013 & 2014 \\
\hline \multicolumn{6}{|l|}{ ASIA (cont.) } \\
\hline 690. Vietnam & 678,02 & $1.970,25$ & $1.499,44$ & $2.588,59$ & 852,65 \\
\hline 696. Camboya (Kampuchea) & 32,07 & 20,65 & 20,11 & 10,93 & 17,54 \\
\hline 700. Indonesia & 563,20 & $2.292,14$ & 843,84 & 556,67 & 588,46 \\
\hline 701. Malaisia & 129,71 & 110,03 & 119,08 & 50,08 & 17,20 \\
\hline 706. Singapur & 172,74 & 107,94 & 6,39 & 7,69 & 14,73 \\
\hline 708. Filipinas & 11,80 & 144,38 & 124,11 & 40,87 & 495,63 \\
\hline 716. Mongolia & & 0,22 & & & \\
\hline 720. China & $44.663,77$ & $25.927,33$ & $19.166,23$ & $43.791,58$ & $40.017,13$ \\
\hline 724. Corea del Norte & & 0,72 & & & \\
\hline 728. Corea del Sur & $50.027,64$ & $3.027,27$ & $1.172,93$ & 393,18 & 491,20 \\
\hline 732. Japón & $2.267,00$ & 663,97 & $2.729,31$ & 548,81 & 794,25 \\
\hline 736. Taiwán & $1.259,79$ & $1.311,71$ & $1.195,09$ & 867,99 & 607,03 \\
\hline 740. Hong-Kong & 542,97 & 207,52 & 69,76 & 50,25 & 100,02 \\
\hline 743. Macao & 0,55 & 0,68 & 1,55 & 1,14 & 2,19 \\
\hline ÁFRICA & $7.894,93$ & $9.492,00$ & $8.267,33$ & $11.391,14$ & $19.195,93$ \\
\hline 204. Marruecos & $4.363,08$ & $8.231,80$ & $6.007,97$ & $5.193,01$ & $4.127,46$ \\
\hline \multicolumn{6}{|l|}{ 208. Argelia } \\
\hline 212. Túnez & 263,25 & 51,33 & 42,16 & 34,93 & 51,70 \\
\hline 220. Egipto & $2.711,20$ & 905,96 & $1.847,18$ & $3.650,91$ & $3.878,50$ \\
\hline 224. Sudán & 15,20 & & 5,80 & & 8,70 \\
\hline 228. Mauritania & 57,14 & 83,77 & 1,42 & 0,95 & \\
\hline 232. Mali & & & & 1,28 & \\
\hline 236. Burkina Faso & 30,21 & 33,63 & 49,67 & & 71,20 \\
\hline 247. Cabo Verde & & & & 21,11 & \\
\hline 264. Sierra Leona & 0,12 & & & & \\
\hline 272. Costa de Marfil & & & 0,04 & & \\
\hline 280. Togo & 13,48 & & & & \\
\hline \multicolumn{6}{|l|}{ 284. Benin } \\
\hline 288. Nigeria & 0,05 & & 0,13 & & \\
\hline 306. República Centroafricana & & & & 1,06 & \\
\hline 314. Gabón & 158,05 & & & & \\
\hline 330. Angola & & & & & 5,70 \\
\hline 334. Etiopía & & 16,63 & 103,78 & & \\
\hline 336. Eritrea & 0,16 & & & & \\
\hline 346. Kenia & & & & 0,36 & 0,08 \\
\hline 350. Uganda & & 0,05 & & & \\
\hline 355. Seychelles & & 0,05 & & & \\
\hline 366. Mozambique & 3,94 & & 1,36 & & \\
\hline 370. Madagascar & 149,77 & 80,23 & 79,48 & 150,22 & 187,95 \\
\hline 373. Mauricio & 13,27 & 11,12 & 9,08 & 9,00 & 5,55 \\
\hline 382. Zimbabwe & & & 6,82 & & $6.208,23$ \\
\hline \multicolumn{6}{|l|}{ 386. Malawi } \\
\hline 388. Sudáfrica & 91,85 & 77,43 & 72,01 & 31,11 & $4.650,85$ \\
\hline 389. Namibia & 24,15 & & 40,14 & & \\
\hline 393. Swazilandia & & & 0,29 & $2.293,90$ & \\
\hline
\end{tabular}


León. Importaciones por áreas geográficas y países (cont.)

\begin{tabular}{|c|c|c|c|c|c|}
\hline Área geográfica/País & 2010 & 2011 & 2012 & 2013 & 2014 \\
\hline OCEANÍA & 36,25 & 528,34 & 672,85 & 264,32 & 290,10 \\
\hline 800. Australia & 26,82 & 520,14 & 667,47 & 259,32 & 287,00 \\
\hline 804. Nueva Zelanda & 9,34 & 8,11 & 5,39 & 4,59 & 2,94 \\
\hline 833. Islas Cocos o islas Keeling & & & & 0,26 & 0,16 \\
\hline 837. Islas Cook & & 0,09 & & & \\
\hline 839. Islas Tokelau & 0,09 & & & 0,16 & \\
\hline SIN DETERMINAR & 779,74 & 213,84 & 601,39 & 160,74 & 178,17 \\
\hline $\begin{array}{l}\text { 959. Países y territorios no } \\
\text { determinados. Intracomunitarios. }\end{array}$ & 779,74 & 213,84 & 601,39 & 160,74 & 178,17 \\
\hline MUNDO & $444.967,25$ & $420.786,83$ & $395.303,14$ & $371.454,69$ & $400.340,32$ \\
\hline
\end{tabular}




\section{J.L. Placer Galán}

León: Exportaciones por Capítulos a los principales países clientes. 2014 (en miles de euros)

\begin{tabular}{|c|c|c|c|c|c|c|}
\hline Capítulos & Francia & Alemania & Italia & $\begin{array}{l}\text { Reino } \\
\text { Unido }\end{array}$ & Portugal & $\begin{array}{c}\text { Países } \\
\text { Bajos }\end{array}$ \\
\hline 01. Animales vivos & $1.385,67$ & & & & 340,56 & \\
\hline 02. Carne y despojos comestibles & $13.682,51$ & 653,47 & 483,15 & 231,29 & $16.716,01$ & 14,10 \\
\hline 03. Pescados, crustáceos y moluscos & 134,27 & & & & 443,15 & \\
\hline 04. Leche, productos lácteos, huevos & 93,85 & $1.245,15$ & $58.235,74$ & $1.102,51$ & $2.429,84$ & 902,59 \\
\hline \multicolumn{7}{|l|}{ 05. Otros productos de origen animal } \\
\hline \multicolumn{7}{|l|}{ 06. Plantas vivas y productos de floricultura } \\
\hline 07. Legumbres, hortalizas & 608,69 & 342,69 & 5,63 & 79,94 & $3.288,47$ & 505,08 \\
\hline 08. Frutos comestibles & $1.162,46$ & 6,73 & $4.172,92$ & & 828,16 & \\
\hline 09. Café, té, yerba mate y especias & & 142,61 & 85,13 & & 77,78 & \\
\hline 10. Cereales & 63,26 & 58,02 & & 8,57 & $7.453,78$ & 37,65 \\
\hline \multicolumn{7}{|l|}{ 11. Productos de la molinería, malta } \\
\hline 12. Semillas y frutos oleaginosos & $2.158,10$ & $4.460,84$ & 73,34 & & 456,40 & \\
\hline 13. Jugos y extractos vegetales & & & & & 2,59 & \\
\hline \multicolumn{7}{|l|}{ 14. Materias trenzables } \\
\hline 15. Grasas, aceite animal y vegetal & & & & & 20,46 & \\
\hline 16. Conservas de carne o pescado & 159,87 & 25,92 & 11,68 & $1.305,77$ & 1,39 & 9,90 \\
\hline 17. Azúcares, artículos de confitería & $12.080,13$ & & $1.019,10$ & $7.756,13$ & 133,83 & 425,46 \\
\hline \multicolumn{7}{|l|}{ 18. Cacao y sus preparaciones } \\
\hline 19. Productos de cereales, de pastelería & & & & & 175,24 & \\
\hline 20. Conservas de verdura o fruta, zumo & 656,95 & 474,23 & 191,70 & 84,63 & $1.388,54$ & 126,92 \\
\hline 21. Preparaciones alimenticias diversas & $1.689,85$ & 40,14 & $10.795,87$ & 496,95 & $1.262,49$ & 385,49 \\
\hline 22. Bebidas de todo tipo (excluidos zumos) & 388,83 & $1.918,24$ & 9,87 & 175,31 & 99,25 & 82,17 \\
\hline 23. Residuos de la industria alimentaria & 315,77 & $3.019,85$ & $2.461,25$ & & 908,13 & $1.534,26$ \\
\hline \multicolumn{7}{|l|}{ 24. Tabaco y sus sucedáneos } \\
\hline 25. Sal, yeso piedras sin trabajar & 287,96 & & & & $2.420,35$ & \\
\hline 26. Minerales, escorias y cenizas & & & & & $2.586,82$ & \\
\hline 27. Combustibles, aceites minerales & $3.534,01$ & 730,77 & 3,05 & 530,98 & 0,18 & 7,63 \\
\hline 28. Productos químicos inorgánicos & & & & & 0,56 & \\
\hline \multicolumn{7}{|l|}{ 29. Productos químicos orgánicos } \\
\hline 30. Productos farmacéuticos & $2.576,21$ & $5.378,28$ & $3.296,92$ & $1.017,24$ & 724,86 & $1.754,76$ \\
\hline 31. Abonos & & & & & 22,62 & \\
\hline 32. Tanino, materias colorantes, pintura & & & & & & $9.232,86$ \\
\hline 33. Aceites esenciales, preparac. de perfumería & 0,03 & & 2,23 & 9,66 & 1,00 & \\
\hline 34. Jabones, lubricantes, ceras & & & & 270,42 & 206,65 & \\
\hline \multicolumn{7}{|l|}{ 35. Materias albuminoideas, colas } \\
\hline 36. Pólvoras y explosivos & & & & 223,15 & 88,15 & \\
\hline \multicolumn{7}{|l|}{ 37. Productos fotográficos o cinematográficos } \\
\hline 38. Otros productos químicos & $1.667,44$ & 147,92 & & 306,79 & & 0,14 \\
\hline 39. Materias plásticas y sus manufacturas & 231,76 & 25,42 & 0,07 & 96,23 & $1.007,68$ & 0,04 \\
\hline 40. Caucho y sus manufacturas & 28,34 & 860,41 & 87,23 & 0,05 & 298,52 & 1,21 \\
\hline 41. Pieles (excepto la peletería) y cueros & & & 159,30 & & & \\
\hline 42. Manufacturas de cuero, marroquinería & 1,38 & & 0,01 & & 0,59 & 0,30 \\
\hline \multicolumn{7}{|l|}{ 43. Peletería y sus confecciones } \\
\hline 44. Madera y sus manufacturas & $1.380,48$ & & $1.437,14$ & 133,62 & $2.654,11$ & $11.793,40$ \\
\hline \multicolumn{7}{|l|}{ 45. Corcho y sus manufacturas } \\
\hline \multicolumn{7}{|l|}{ 46. Manufacturas de cestería } \\
\hline 47. Pasta de madera, papel reciclado & & & & & 0,06 & \\
\hline 48. Papel y cartón, sus manufacturas & 159,05 & 22,09 & 57,75 & 48,70 & 61,02 & 12,90 \\
\hline 49. Libros, publicaciones, artes gráficas & 0,89 & 2,45 & 17,42 & 9,20 & 386,58 & \\
\hline
\end{tabular}


León: Exportaciones por Capítulos a los principales países clientes. 2014 (en miles de euros) (cont.)

\begin{tabular}{|c|c|c|c|c|c|c|}
\hline Capítulos & Francia & Alemania & Italia & $\begin{array}{l}\text { Reino } \\
\text { Unido }\end{array}$ & Portugal & $\begin{array}{l}\text { Países } \\
\text { Bajos }\end{array}$ \\
\hline \multicolumn{7}{|l|}{ 50. Seda } \\
\hline \multicolumn{7}{|l|}{ 51. Lana y pelo fino } \\
\hline 52. Algodón & & & & & 1,71 & \\
\hline \multicolumn{7}{|l|}{ 53. Otras fibras textiles vegetales } \\
\hline 54. Filamentos sintéticos o artificiales & & & & & 4,26 & \\
\hline \multicolumn{7}{|l|}{ 55. Fibras sintéticas o artificiales discontinuas } \\
\hline \multicolumn{7}{|l|}{ 56. Fieltro, tela sin tejer, cordelería } \\
\hline \multicolumn{7}{|l|}{ 57. Alfombras y revestimientos textiles para el suelo } \\
\hline \multicolumn{7}{|l|}{ 58. Tejidos especiales, tapicería, bordados } \\
\hline \multicolumn{7}{|c|}{ 59. Tejidos recubiertos, técnicos de materias textiles } \\
\hline \multicolumn{7}{|l|}{ 60. Tejidos de punto } \\
\hline 61. Prendas de vestir de punto & 39,88 & 1,28 & 51,09 & 0,02 & 50,54 & 0,12 \\
\hline 62. Prendas de vestir, excepto las de punto & 324,58 & 0,08 & 302,88 & 0,05 & 651,59 & 5,61 \\
\hline 63. Demás artículos textiles, prendería & 20,55 & 24,12 & 0,02 & 4,64 & 7,07 & 0,34 \\
\hline 64. Calzado y sus partes & 16,90 & & 18,19 & & 42,02 & \\
\hline 65. Artículos de sombrerería & 45,49 & 31,46 & 1,60 & & 14,90 & 11,65 \\
\hline 66. Paraguas, sombrillas, bastones & & & 0,02 & & & \\
\hline \multicolumn{7}{|l|}{ 67. Plumas y plumón preparados } \\
\hline 68. Manufacturas de piedra, yeso & $37.950,20$ & $7.372,39$ & 78,10 & $19.141,43$ & 354,88 & 21,47 \\
\hline 69. Productos cerámicos & 29,18 & & & & 99,78 & \\
\hline 70. Vidrio y sus manufacturas & $12.019,77$ & 128,26 & $9.837,66$ & 719,81 & $18.179,39$ & $3.389,15$ \\
\hline 71. Piedras y metales preciosos, bisutería & & 112,66 & & & 24,48 & \\
\hline 72. Fundición, hierro y acero & $11.379,85$ & $68.258,17$ & $47.054,99$ & $17.137,18$ & $3.835,03$ & 465,86 \\
\hline 73. Manufacturas de fundición, hierro y acero & $2.032,88$ & $26.893,14$ & 242,57 & 322,78 & 72,16 & 264,63 \\
\hline 74. Cobre y sus manufacturas & $1.507,87$ & $1.466,22$ & & & $2.968,17$ & \\
\hline \multicolumn{7}{|l|}{ 75. Níquel y sus manufacturas } \\
\hline 76. Aluminio y sus manufacturas & & 88,71 & & & 470,02 & 165,04 \\
\hline \multicolumn{7}{|l|}{ 78. Plomo y sus manufacturas } \\
\hline 79. Cinc y sus manufacturas & 245,18 & & 5,28 & & & \\
\hline 80. Estaño y sus manufacturas & & & & & 34,14 & \\
\hline 81. Demás metales comunes, cermets & & & 29,22 & & 9,44 & \\
\hline 82. Herramientas y cuchillos metálicos & & 20,41 & & & 12,75 & \\
\hline 83. Manufacturas diversas de metales & & 1,64 & 13,80 & & & \\
\hline 84. Máquinas y aparatos mecánicos & $12.010,26$ & $4.889,67$ & $4.471,73$ & $4.005,17$ & $1.112,60$ & $2.498,64$ \\
\hline 85. Máquinas, aparatos y material eléctricos & $141.118,42$ & $61.591,53$ & $24.538,35$ & $33.601,43$ & $17.631,09$ & $25.856,98$ \\
\hline \multicolumn{7}{|l|}{ 86. Vehículos, material ferroviarios } \\
\hline 87. Vehículos automóviles, tractores & 3,29 & 259,83 & & 32,93 & $1.051,76$ & 95,07 \\
\hline \multicolumn{7}{|l|}{ 88. Aeronaves, vehículos espaciales } \\
\hline \multicolumn{7}{|l|}{ 89. Barcos y embarcaciones } \\
\hline 90. Aparatos ópticos, de medida, médicos & & 51,76 & & 144,33 & 93,56 & 160,04 \\
\hline \multicolumn{7}{|l|}{ 91. Relojería } \\
\hline \multicolumn{7}{|l|}{ 92. Instrumentos musicales } \\
\hline 93. Armas y municiones, accesorios & 420,98 & & & & 542,68 & \\
\hline 94. Muebles, sillas, lámparas & $1.666,14$ & 631,54 & 79,72 & & 830,86 & 2,37 \\
\hline 95. Juguetes, juegos, artículos deportivos & & & & 0,50 & & \\
\hline 96. Manufacturas diversas & & & & & 2,49 & 0,12 \\
\hline \multicolumn{7}{|l|}{ 97. Objetos de arte, antigüedades } \\
\hline \multicolumn{7}{|l|}{ 98. Conjuntos industriales } \\
\hline \multicolumn{7}{|l|}{ 99. Conjuntos de otros productos } \\
\hline TOTAL PAÍS & $249.374,17$ & $189.136,79$ & $110.607,20$ & $87.583,65$ & $71.365,16$ & $58.342,17$ \\
\hline
\end{tabular}




\section{J .L. Pla cer Ga lán}

León: Importaciones por Capítulos de los principales países proveedores. 2014 (en miles de euros)

\begin{tabular}{|c|c|c|c|c|c|c|c|}
\hline Capítulos & Francia & Alemania & China & Italia & Portugal & Bélgica & USA \\
\hline 01. Animales vivos & 386,67 & & & & $3.357,40$ & & \\
\hline 02. Carne y despojos comestibles & 39,49 & 60,14 & & 95,74 & & & \\
\hline 03. Pescados, crustáceos y moluscos & 39,43 & & $1.863,66$ & 963,10 & & & \\
\hline 04. Leche, productos lácteos, huevos & $3.626,47$ & $4.162,88$ & & 606,06 & $2.262,47$ & & \\
\hline 05. Otros productos de origen animal & & 0,53 & & & & & 436,29 \\
\hline 06. Plantas vivas y productos de floricultura & 0,20 & & & & & & \\
\hline 07. Legumbres, hortalizas & 558,26 & 12,41 & $5.774,38$ & 252,68 & 183,89 & 313,85 & $17.389,63$ \\
\hline 08. Frutos comestibles & $2.154,54$ & 0,03 & & 236,00 & 393,19 & & 67,70 \\
\hline 09. Café, té, yerba mate y especias & 2,18 & 212,03 & 615,49 & & & & \\
\hline 10. Cereales & $7.657,37$ & 0,02 & & 75,73 & 0,09 & & \\
\hline 11. Productos de la molinería, malta & 108,36 & 95,47 & & 41,75 & & 181,42 & \\
\hline 12. Semillas y frutos oleaginosos & $3.642,48$ & 494,11 & 564,68 & 96,89 & 15,87 & & 54,44 \\
\hline 13. Jugos y extractos vegetales & & 743,88 & & 229,68 & & 131,08 & \\
\hline 14. Materias trenzables & 17,25 & 0,02 & & & & & \\
\hline 15. Grasas, aceite animal y vegetal & 19,82 & 0,04 & & 8,55 & 10,32 & & \\
\hline 16. Conservas de carne o pescado & 198,51 & & 38,02 & 100,13 & 18,60 & 19,00 & \\
\hline 17. Azúcares, artículos de confitería & 170,49 & 0,57 & & 1,84 & $1.249,35$ & 47,84 & \\
\hline 18. Cacao y sus preparaciones & 15,21 & 2,69 & & 78,80 & & & \\
\hline 19. Productos de cereales, de pastelería & $1.015,75$ & 793,70 & & 381,96 & 951,26 & & \\
\hline 20. Conservas de verdura o fruta, zumo & $4.340,42$ & 163,07 & & 29,36 & 30,24 & 357,88 & \\
\hline 21. Preparaciones alimenticias diversas & 104,09 & 279,15 & & 114,23 & 226,05 & 32,67 & 0,66 \\
\hline 22. Bebidas de todo tipo (excluidos zumos) & $2.000,72$ & & & 295,45 & & & \\
\hline 23. Residuos de la industria alimentaria & $2.036,13$ & $2.995,53$ & 0,06 & 396,27 & & 13,49 & \\
\hline \multicolumn{8}{|l|}{ 24. Tabaco y sus sucedáneos } \\
\hline 25. Sal, yeso piedras sin trabajar & 100,44 & 4,63 & 56,49 & & 54,11 & 43,91 & \\
\hline 26. Minerales, escorias y cenizas & & 52,51 & & & 43,06 & & \\
\hline 27. Combustibles, aceites minerales & 193,02 & 109,39 & & 2,28 & 622,19 & & 0,98 \\
\hline 28. Productos químicos inorgánicos & 23,55 & 88,37 & 22,53 & & 77,30 & 28,18 & 2,83 \\
\hline 29. Productos químicos orgánicos & 670,67 & 969,08 & 921,35 & $10.525,72$ & 570,04 & 302,44 & 186,42 \\
\hline 30. Productos farmacéuticos & 324,04 & 322,63 & 259,44 & 251,75 & & & 255,14 \\
\hline 31. Abonos & $2.790,48$ & 6,28 & & & 715,50 & & \\
\hline 32. Tanino, materias colorantes, pintura & 129,73 & 20,87 & 0,71 & $2.403,18$ & 12,94 & 339,44 & $1.610,12$ \\
\hline 33. Aceites esenciales, preparac. de perfumería & 171,40 & 602,18 & 0,81 & 574,79 & & 61,82 & 0,05 \\
\hline 34. Jabones, lubricantes, ceras & 41,94 & 5,97 & & 384,32 & 0,11 & 49,82 & 7,48 \\
\hline 35. Materias albuminoideas, colas & 202,52 & 199,74 & 14,72 & 2,41 & & 121,07 & 217,31 \\
\hline 36. Pólvoras y explosivos & 803,36 & $3.097,25$ & & & $4.398,32$ & & \\
\hline 37. Productos fotográficos o cinematográficos & & & 0,24 & 0,29 & & & 0,61 \\
\hline 38. Otros productos químicos & 670,55 & 410,77 & 16,35 & 14,92 & 295,41 & 15,12 & 90,31 \\
\hline 39. Materias plásticas y sus manufacturas & $5.763,54$ & $2.947,39$ & 382,78 & $2.190,24$ & $2.375,70$ & 593,74 & 257,09 \\
\hline 40. Caucho y sus manufacturas & 153,26 & $1.211,03$ & 90,11 & 30,72 & 77,27 & 51,02 & 18,85 \\
\hline 41. Pieles (excepto la peletería) y cueros & 1,72 & 1,62 & & 43,15 & 642,08 & & \\
\hline 42. Manufacturas de cuero, marroquinería & 72,91 & 222,59 & $1.524,64$ & 18,18 & 0,91 & 0,89 & 4,40 \\
\hline 43. Peletería y sus confecciones & & & 8,86 & 86,09 & & & \\
\hline 44. Madera y sus manufacturas & 486,56 & 249,53 & $1.684,75$ & 3,26 & 506,29 & $1.135,90$ & \\
\hline 45. Corcho y sus manufacturas & 13,42 & 0,04 & & 0,03 & 225,17 & & \\
\hline 46. Manufacturas de cestería & 0,02 & 7,02 & & & & & \\
\hline 47. Pasta de madera, papel reciclado & 1,18 & & & & & 36,05 & \\
\hline 48. Papel y cartón, sus manufacturas & 518,05 & $1.735,24$ & 229,30 & $1.460,06$ & 962,26 & 5,98 & 32,84 \\
\hline 49. Libros, publicaciones, artes gráficas & 13,37 & 9,08 & 115,64 & 19,29 & 0,15 & 0,57 & 7,88 \\
\hline
\end{tabular}


León: Importaciones por Capítulos de los principales países proveedores. 2014 (en miles de euros) (cont.)

\begin{tabular}{|c|c|c|c|c|c|c|c|}
\hline Capítulos & Francia & Alemania & China & Italia & Portugal & Bélgica & USA \\
\hline 50. Seda & & & & 8,57 & & & \\
\hline 51. Lana y pelo fino & & & & 5,52 & & & \\
\hline 52. Algodón & & & 0,61 & 161,09 & 116,20 & & 1,15 \\
\hline 53. Otras fibras textiles vegetales & & 0,06 & & & & & \\
\hline 54. Filamentos sintéticos o artificiales & 0,15 & 13,06 & 41,11 & 2,36 & & & 0,65 \\
\hline 55. Fibras sintéticas o artificiales discontinuas & & & 56,32 & 41,38 & 31,27 & & \\
\hline 56. Fieltro, tela sin tejer, cordelería & 8,72 & 1,09 & 17,55 & 0,09 & 13,31 & 0,02 & 0,07 \\
\hline 57. Alfombras y revestimientos textiles para el suelo & 0,19 & & & & 5,89 & 4,71 & \\
\hline 58. Tejidos especiales, tapicería, bordados & 0,48 & 0,60 & 0,42 & 0,17 & 3,60 & & \\
\hline 59. Tejidos recubiertos, técnicos de materias textiles & 0,24 & 28,42 & 2,20 & & & 0,13 & 0,13 \\
\hline 60. Tejidos de punto & & 0,03 & 0,20 & & & & \\
\hline 61. Prendas de vestir de punto & 416,83 & 167,56 & $1.057,07$ & 328,44 & 59,81 & 28,09 & 5,52 \\
\hline 62. Prendas de vestir, excepto las de punto & 151,70 & 205,88 & $4.355,08$ & 734,72 & 68,44 & 12,88 & 2,51 \\
\hline 63. Demás artículos textiles, prendería & 34,28 & 7,67 & 18,10 & 0,65 & 73,41 & 13,52 & \\
\hline 64. Calzado y sus partes & 146,72 & 6,79 & 286,82 & 76,85 & 34,40 & 176,09 & 0,94 \\
\hline 65. Artículos de sombrerería & 1,61 & 11,70 & 65,92 & 3,00 & 0,03 & 0,05 & 1,34 \\
\hline 66. Paraguas, sombrillas, bastones & 20,37 & 0,07 & 0,05 & & & & \\
\hline 67. Plumas y plumón preparados & 0,63 & 0,41 & 20,68 & & & & \\
\hline 68. Manufacturas de piedra, yeso & 569,26 & 97,75 & $1.697,87$ & 17,88 & 674,40 & 82,60 & 8,07 \\
\hline 69. Productos cerámicos & 298,31 & 772,30 & 146,48 & 99,96 & 493,51 & 0,87 & 0,06 \\
\hline 70. Vidrio y sus manufacturas & $2.570,00$ & 397,63 & $1.002,29$ & 38,56 & $1.182,63$ & $3.973,17$ & 1,13 \\
\hline 71. Piedras y metales preciosos, bisutería & 0,41 & 149,74 & 18,27 & 148,70 & 0,60 & 2,23 & 6,81 \\
\hline 72. Fundición, hierro y acero & 70,72 & 52,90 & 12,75 & 57,67 & 694,87 & & 1,18 \\
\hline 73. Manufacturas de fundición, hierro y acero & 481,75 & 814,31 & 932,20 & 196,95 & 685,52 & 64,52 & 14,30 \\
\hline 74. Cobre y sus manufacturas & 385,96 & 1,59 & 0,19 & 163,98 & 769,98 & $12.554,58$ & 0,07 \\
\hline 75. Níquel y sus manufacturas & 0,52 & & 0,20 & & 0,09 & & \\
\hline 76. Aluminio y sus manufacturas & 104,41 & $3.055,70$ & 82,90 & 168,33 & 641,31 & 52,47 & 0,72 \\
\hline \multicolumn{8}{|l|}{ 78. Plomo y sus manufacturas } \\
\hline 79. Cinc y sus manufacturas & & 0,97 & 0,77 & & & & \\
\hline 80. Estaño y sus manufacturas & & & 0,02 & & 520,40 & & 0,14 \\
\hline 81. Demás metales comunes, cermets & 12,19 & & & & 2,95 & & \\
\hline 82. Herramientas y cuchillos metálicos & 65,10 & 255,05 & 400,12 & 2,29 & 3,58 & 2,08 & 48,61 \\
\hline 83. Manufacturas diversas de metales & 19,54 & 13,29 & 50,29 & 22,28 & 2,84 & 6,42 & 2,56 \\
\hline 84. Máquinas y aparatos mecánicos & $1.081,64$ & $5.990,18$ & $5.724,04$ & $2.600,00$ & 850,74 & 527,48 & 357,36 \\
\hline 85. Máquinas, aparatos y material eléctricos & 290,36 & 465,72 & $7.771,64$ & 223,57 & 33,89 & 763,61 & 86,08 \\
\hline 86. Vehículos, material ferroviarios & & 33,08 & & 23,54 & 18,27 & & \\
\hline 87. Vehículos automóviles, tractores & $1.564,99$ & $2.654,55$ & 680,40 & $2.051,69$ & 334,94 & $1.888,85$ & 39,13 \\
\hline 88. Aeronaves, vehículos espaciales & & & 0,30 & 1,80 & & & \\
\hline \multicolumn{8}{|l|}{ 89. Barcos y embarcaciones } \\
\hline 90. Aparatos ópticos, de medida, médicos & 232,05 & $3.836,43$ & 226,09 & 209,58 & 21,46 & 191,85 & 269,66 \\
\hline 91. Relojería & 178,48 & 4,55 & 3,93 & 0,12 & & 2,58 & 1,04 \\
\hline 92. Instrumentos musicales & 0,03 & 1,08 & 0,16 & 1,36 & & & 1,37 \\
\hline 93. Armas y municiones, accesorios & 136,26 & $2.126,22$ & & $3.115,26$ & 48,72 & & 91,90 \\
\hline 94. Muebles, sillas, lámparas & 189,58 & 80,35 & 811,16 & 83,60 & 83,43 & 12,23 & 12,59 \\
\hline 95. Juguetes, juegos, artículos deportivos & 40,80 & 2,84 & 59,65 & 0,65 & & 0,05 & 10,88 \\
\hline 96. Manufacturas diversas & 14,02 & 32,20 & 164,29 & 2,01 & 7,70 & & 41,08 \\
\hline 97. Objetos de arte, antigüedades & & & 0,12 & & & & 2,46 \\
\hline \multicolumn{8}{|l|}{ 98. Conjuntos industriales } \\
\hline 99. Conjuntos de otros productos & & 82,18 & 123,85 & & & & 27,28 \\
\hline TOTAL PAÍS & $45.717,32$ & $39.417,48$ & $32.379,09$ & $30.689,89$ & $21.951,96$ & $23.930,41$ & $3.851,93$ \\
\hline
\end{tabular}

